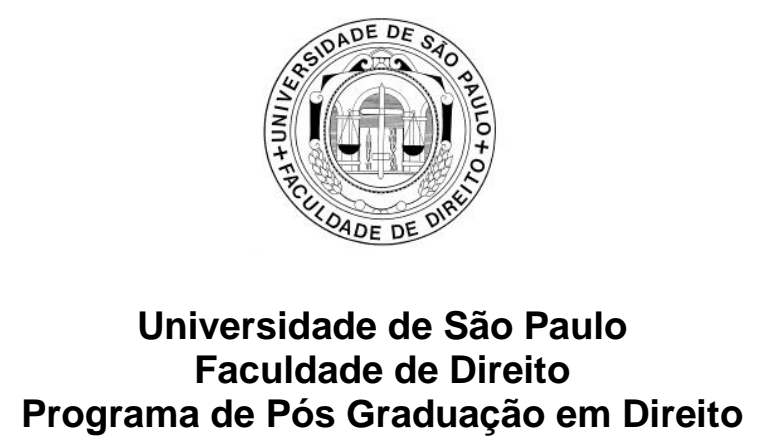

MARCOS ROBERTO FRANCO

\title{
O PODER DE POLÍCIA NO CONTEXTO ATUAL
}

São Paulo

2012 


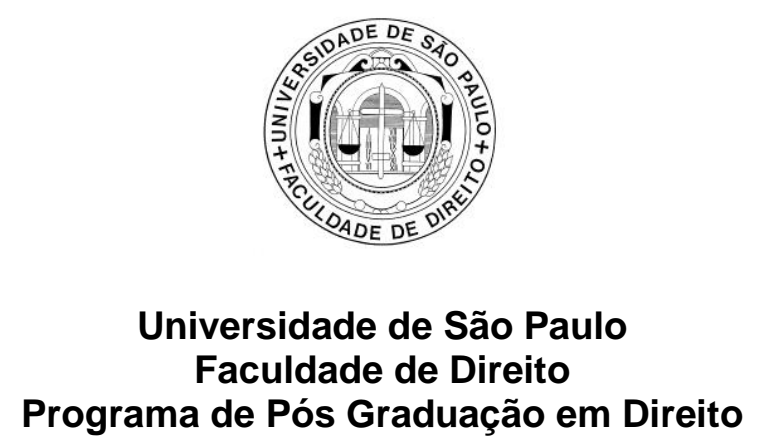

MARCOS ROBERTO FRANCO

\section{O PODER DE POLÍCIA NO CONTEXTO ATUAL}

Dissertação de Mestrado apresentada à Faculdade de Direito da Universidade de São Paulo, sob a orientação do Professor Doutor EDMIR NETTO DE ARAÚJO.

São Paulo

2012 


\section{MARCOS ROBERTO FRANCO}

O PODER DE POLÍCIA NO CONTEXTO ATUAL

BANCA EXAMINADORA:

Prof. Dr. Edmir Netto de Araújo FDUSP

FDUSP

INSTITUIÇÃO:

Aprovado em: 
Dedico este trabalho:

Aos meus pais: Armando Franco (in memorian) e Irene Franco, pela demonstração de amor impressionante.

À minha linda esposa, Juliana, pelo apoio incondicional.

Aos meus filhos: Marcos e Giovanna, que todos os dias me enchem de orgulho e alegria. 


\section{AGRADECIMENTOS:}

Ao Professor Dr. Edmir Netto de Araújo que muito além da orientação segura, oferece aos seus alunos a possibilidade de desfrutar de sua experiência e preciosa amizade.

Ao amigo Guilherme Bueno de Camargo pelo incentivo e auxílio imprescindíveis para a concretização deste sonho acadêmico. 


\title{
RESUMO:
}

O Estado contemporâneo exigiu dos mecanismos de Direito, em especial do Direito Administrativo, uma forte atualização voltada a atender de modo satisfatório as exigentes demandas sociais destes novos tempos. O trabalho que ora apresentamos tem como objetivo questionar e apontar a importância e o adequado papel do poder de polícia numa sociedade democrática, participativa e moderna.

Para tanto, a pesquisa inicia-se trazendo à lembrança as principais características do instituto, desde sua história mais remota, passando pelas principais críticas que o tema enfrentou para então, à luz das ideias democráticas mais avançadas, verificar se esta função pública é adequada e apta para figurar entre os mecanismos de promoção de um convívio social justo e equilibrado.

\begin{abstract}
:
The contemporary State demanded of the mechanisms of Law, Administrative Law in particular, a strong update aimed to satisfactorily meet the stringent social demands of these new times. The work presented aims to question and highlight the importance and proper role of the police power in a democratic society, participatory and modern.

To this end, the research starts bringing to mind the main features of the institute since its earliest history, through the main criticisms that the theme faced, to then, in the light of the most advanced democratic ideas, check whether this public function is appropriate and apt to be among the mechanisms that promote a fair and balanced social life.
\end{abstract}




\section{I - O HISTÓRICO DE PODER DE POLÍCIA}

I.1 - Origem da expressão "Poder de Polícia". .............................................................. 06

I.2 - O Poder de Polícia na Grécia. ............................................................................... 09

I.3 - O Poder de Polícia em Roma. ............................................................................ 12

I.4 - O Poder de Polícia na Idade Média. ..................................................................... 15

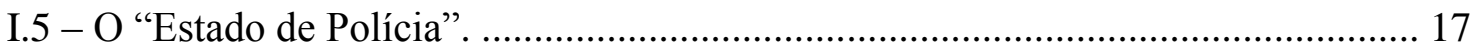

\section{II - A NOÇ̃̃o CLÁSSICA DO PODER DE POLÍCIA}

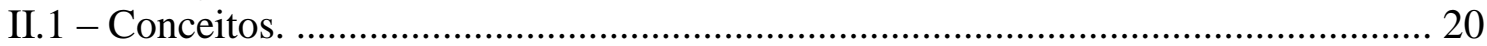

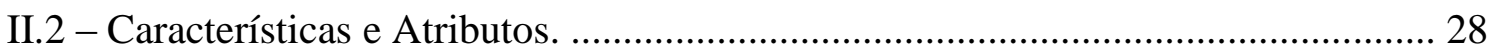

II.2.1 - Supremacia Geral. ............................................................................ 29

II.2.2 - Competência. ………………………………………………………..... 32

II.2.3 - Atividade predominante negativa. ................................................................ 33

II.2.4 - Atividade preventiva/repressiva. ................................................................. 35

II.2.5 - Atividade discricionária/vinculada. .............................................................. 37

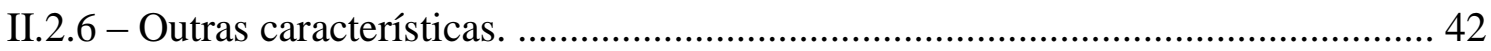

\section{III - CRÍTICAS CLÁSSICAS E MODERNAS AO PODER DE POLÍCIA}

III.1 - Críticas à Noção de Poder de Polícia. ................................................................. 46

III.2 - Críticas à denominação: Poder de Polícia. ......................................................... 51

\section{IV - DAS TRANSFORMAÇÕES NO ESTADO E OS REFLEXOS NO PODER DE POLÍCIA CONTEMPORÃNEO}

IV.1 - Do Estado Absoluto ao Estado de Direito. ………………………………….... 59

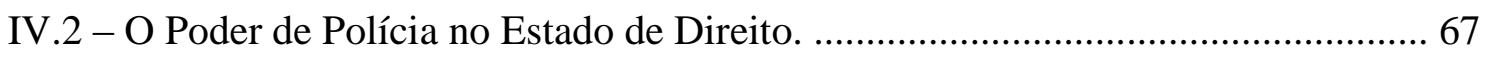

IV.3. - Do "Estado Legal" ou legalismo. …………………………………………....... 71

IV.4 - O Estado Social de Direito e o Poder de Polícia. ................................................... 74

\section{V - O PODER DE POLÍCIA NO ESTADO CONTEMPORÂNEO}

V.1 - Estado Contemporâneo e Poder de Polícia. …………………………………….... 78

V.2 - O Princípio da Soberania Popular e o Poder de Polícia. ....................................... 87

V.3 - A Participação Popular como fator de legitimação do Exercício do Poder de Polícia. ........................................................................... 90

V.4. - A Prática do Poder de Polícia no Estado Contemporâneo. ....................................... 99

V.4.1 - O Poder/Dever de Agir. ............................................................................... 100

V.4.2 - Atividade Privativamente Pública - Possibilidades de delegação. ................... 102

V.4.3 - A Omissão quanto ao Exercício do Poder de Polícia e suas consequências. ... 106

V.4.4 - A Questão da Auto-Executoriedade no exercício do Poder de Polícia. ............ 110

V.4.5 - O Abuso e o Desvio de Poder de Polícia - A Descaracterização do Instituto. 116 V.5 - O Poder de Polícia num Ambiente de Democracia Participativa/Deliberativa. 125

VI - CONCLUSÕES. ...................................................................................................... 141

BIBLIOGAFIA/REFERÊNCIAS.........................................................................145 


\section{INTRODUÇÃO}

O poder de polícia é, a um tempo, um dos mais clássicos e um dos mais contemporâneos temas de Direito Administrativo. Permeado de grandes controvérsias $^{1}$, o estudo deste instituto vem merecendo hodiernamente uma releitura acurada.

Isto porque, a complexidade da vida pós-moderna, especialmente nos grandes centros urbanos, fez com que houvesse profundas modificações no modo do exercício dos direitos fundamentais e também nas formas de intervenção do Estado em sua função de limitar e equilibrar o exercício das liberdades e direitos.

E é esta justamente a questão central a ser enfrentada nesta pesquisa, ou seja, a busca nas origens do instituto, em sua história e desenvolvimento e, principalmente, na compreensão de sua importância contemporânea, do modo adequado de utilização deste importante mecanismo de proteção do sistema social.

Veremos que se por um lado resta indiscutível e consagrada a importância da proteção ao exercício dos direitos e liberdades individuais, não se olvida que tais valores não podem ser tratados como absolutos, sob pena de se tornarem eles mesmos nocivos à coletividade.

Com efeito, é da natureza do homem a pretensão de sobrepor-se ao outro, num movimento de imposição do seu “eu”. Pascál já advertia que:

Numa palavra, o "eu" tem duas qualidades. É injusto em si por se fazer o centro de tudo. É incômodo aos outros por querer subjugá-los, porque cada "eu" é inimigo e gostaria de ser tirano de todos os outros ${ }^{2}$

\footnotetext{
${ }^{1}$ MOREIRA NETO, Diogo de Figueiredo, Curso de Direito Administrativo, $15^{\mathrm{a}}$ ed., Ed. Forense, 2009, p. 441.

${ }^{2}$ Apud. COMTE-SPONVILLE, André in: Pequeno Tratado das Grandes Virtudes, Martins Fontes, São Paulo, 2007, p 307 - referindo-se a Pascál in Pensées (pensamentos), ed. Lafuma.
} 
Spinoza, com mais contundência afirma em seu "Tratado Político" que:

Na verdade, os homens são feitos de tal modo que não podem viver sem uma lei comum.

Ademais, cada qual deseja que os outros vivam conforme sua própria compleição, aprovem o que aprova, e rejeitem o que rejeita. Resultando que, querendo todos ser os primeiros, surjam conflitos entre eles, procurem esmagar-se uns aos outros, e que o vencedor se glorie mais por ter triunfado sobre seu rival do que por haver obtido qualquer vantagem para si mesmo. ${ }^{3}$

Em razão desta sua natureza egocêntrica, resta incontroverso que sem controle e sem leis, a ambição invariavelmente conduz o homem à destruição do outro, na busca para fixar seu espaço ou suas convicções. ${ }^{4}$ Com efeito, a convivência em qualquer espécie de agrupamento humano reclama como condição fundamental a sua estabilidade, a adoção de um regramento das condutas de seus integrantes. ${ }^{5}$

É por isto que o exercício das liberdades e direitos precisa encontrar limites. Mas limites que sejam impostos pelo real interesse público, apurado em meio a um contexto moderno, que privilegia de fato as novas formas de organização social e as necessidades de controle das mais variadas espécies de comunidades.

Para a consecução deste interesse público moderno e específico, cujo conceito preciso será objeto de análise mais aprofundada, tendo em vista sua especial implicação para o estudo que fazemos, é investido o Estado de supremacia sobre o particular, cingindo-se de poderes limitadores e impositivos de comportamentos, no intuito de estabelecer um equilíbrio na convivência comum e evitar o caos generalizado ${ }^{6}$. A imposição de limitações administrativas é, pois, questão vital à convivência social ${ }^{7}$ e sob este enfoque é que será aqui estudado.

\footnotetext{
${ }^{3}$ SPINOZA, Baruch, Tratado Político, Ícone Editora, 2a ed., São Paulo, 1994, p. 24/25.

${ }^{4}$ SIRAQUE, Vanderlei, Controle Social da Função Administrativa do Estado, Ed. Saraiva, $2^{\mathrm{a}}$ ed., São Paulo, 2009, p. 01.

${ }^{5}$ SUNDFELD, Carlos Ari, Fundamentos de Direito Público, $4^{\mathrm{a}}$ ed., Malheiros Editores, São Paulo, 2009 , p. 19.

${ }^{6}$ ARAÚJO, Edmir Netto de, Curso de Direito Administrativo, Saraiva, 5ª Ed., São Paulo, 2010, p. 1.044.

7 BANDEIRA DE MELLO, Celso Antônio, Curso de Direito Administrativo, Malheiros, 21 a Ed., São Paulo, 2006, p. 776.
} 
Conforme demonstraremos, o exercício do poder de polícia tem sua importância evidenciada na medida em que se apresenta como um dos mais importantes mecanismos do Direito para preservação da sociedade organizada.

Nas palavras de Marçal Justen Filho:

A satisfação dos direitos fundamentais compreende uma atuação estatal conformadora da autonomia privada. ${ }^{8}$

Com efeito, é típico de qualquer ordenamento jurídico que existam mecanismos que tenham como objetivo dar contornos aos direitos fundamentais e o poder de polícia coloca-se justamente no ponto de atrito entre a liberdade e a autoridade, entre o Estado e o indivíduo. ${ }^{9}$

Na medida em que a individualidade ganha força no sistema social, impondo-se frente às decisões centrais, torna-se necessário o surgimento de estruturas normativas e práticas que nada mais são do que sistemas auto inibidores. ${ }^{10}$

Através do poder de polícia o Estado realiza o que Clóvis Beznos ${ }^{11}$ denominou de "entropia negativa", ou seja, a característica dos sistemas vivos de procurarem sua autopreservação, fugindo da tendência natural de degenerar-se com o tempo.

Será demonstrado também que para cumprir sua finalidade de atender ao interesse público e alcançar o bem estar comum, o Estado exerce seus poderes adstritos a dois parâmetros: suas prerrogativas e sua sujeição aos limites legais.

Tem o poder de polícia, portanto, um caráter positivo intrínseco de produção de equilíbrio da convivência social, característica esta, de importância exponencial na sociedade moderna, organizada de modo cada vez mais denso do ponto de vista demográfico.

Por meio da análise do tema através do tempo, verificaremos que, em detrimento das mazelas que o abuso do poder produziu, a imposição de limites é vital a sociedade. Neste sentido, Maria Sylvia Zanella Di Pietro, lançando mão dos ensinamentos de Zanobini lembra que:

\footnotetext{
${ }^{8}$ JUSTEN FILHO, Marçal, Curso de Direito Administrativo, 3 a edição, Saraiva, São Paulo, 2008, p. 459.

9 MEDUAR, Odete, Poder de Polícia, in Boletim de Direito Administrativo, São Paulo, v. 12, no 12 , p. 8149, dezembro de 1996., p. 814.

${ }^{10}$ HABERMAS, Jürgen, A Crise de Legitimidade no Capitalismo Tardio, Edições Tempo Brasileiro, Rio de Janeiro, 1999, p. 26.

${ }^{11}$ BEZNOS, Clóvis, Poder de Polícia, Revista dos Tribunais, São Paulo, 1979, p. 66.
} 
....a ideia de limite surge do próprio conceito de direito subjetivo: tudo aquilo que é juridicamente garantido é também juridicamente limitado"12

Veremos que, oscilando entre períodos de intromissão máxima e até mesmo despótica, até a ideia de não intervenção na propriedade e na vida privada, o exercício do poder de polícia parece hoje caminhar na direção do estabelecimento de uma nova fórmula no relacionamento entre o particular e o Estado, em que a imposição de limites é exercida de modo legitimado, através da utilização de mecanismos democráticos que estimulem a participação do indivíduo na solução dos problemas locais, regionais e até nacionais.

Neste novo contexto, a vontade soberana que legitima a intervenção estatal no âmbito das liberdades individuais é a expressão da vontade popular manifestada pela lei democraticamente produzida e por atos que correspondam à interesses legitimados.

Se no sistema jurídico clássico (liberal), só a lei poderia justificar a imposição de uma ação ou restringir o exercício de uma atividade ${ }^{13}$, no Estado contemporâneo, o exercício do poder de polícia deve corresponder, como veremos, o mais fielmente possível a vontade dos cidadãos que serão objeto das restrições e limitações no exercício de seus direitos.

Procuraremos demonstrar que o Estado de Direito contemporâneo não se contenta com a simples expressão formal da legalidade. O Estado exerce um poder limitador de liberdades, o poder de polícia, para que as liberdades possam ser garantidas a todos, e o faz por força da lei que não é outra coisa, senão a expressão da vontade livre de um povo soberano ${ }^{14}$.

Ao tratar do poder de polícia, não deixaremos de enfrentar as críticas históricas e modernas que vão desde controvérsias ligadas à autonomia do instituto em relação aos demais atos administrativos, até aquelas ligadas a correta nomenclatura a ser empregada.

Não nos furtaremos de elaborar um panorama das características da sociedade contemporânea e das implicações destas no modo de agir do Estado, no que

\footnotetext{
${ }^{12}$ DI PIETRO, Maria Sylvia Zanella, Direito Administrativo, Atlas, 20ª Ed., São Paulo, 2007, p. 101.

${ }^{13}$ BEZNOS, Clóvis, Poder de Polícia, Revista dos Tribunais, São Paulo, 1979, p. 67.

${ }^{14}$ Conf. art. 1 , único da Constituição Federal de 1988: "Todo poder emana do povo, que o exerce por meio de representantes eleitos, ou diretamente, nos termos desta Constituição."
} 
diz respeito ao exercício do poder de polícia. Conforme veremos, o Estado tem sido compelido a agir nos mais diferentes setores, de modo cada vez mais invasivo, extrapolando as questões clássicas, ligadas a segurança, a moralidade e a salubridade, passando a atuar em quase todos os setores sociais.

Ao final do trabalho apresentaremos, ainda, uma visão sobre as formas de participação popular (democracia participativa/deliberativa) na formulação dos mecanismos de exercício do poder de polícia, apresentando-os como instrumento hábil e moderno de legitimação da intervenção estatal, especialmente nas grandes cidades.

Enfim, tentaremos por em prática o conselho de Álvaro Lazzarini segundo o qual:

É fundamental, assim, no campo do saber jurídico, conhecer o importantíssimo capítulo do Direito Administrativo que é o poder de policia, porque, conhecendo-o nos seus aspectos fundamentais, ao certo Administração Pública e administrado, este o cidadão, ficam em condições ideais de conhecer os seus limites, ou seja, a Administração terá condições de aquilatar até onde poderá exercitar este seu poder administrativo sem lesar o direito do administrado, respeitando, pois, a cidadania e, bem por isso, os direitos humanos fundamentais, enquanto o mesmo cidadão poderá aquilatar, no Estado Democrático de Direito, até que ponto deverá respeito ao ato de polícia, como tal considerado o que decorrer do exercício do poder de polícia. ${ }^{15}$

\footnotetext{
${ }^{15}$ LAZZARINI, Álvaro, Temas de Direito Administrativo, $2^{a}$ ed., Editora Revista dos Tribunais, São Paulo,
} 2003, p. 271. 


\title{
I - O HISTÓRICO DO PODER DE POLÍCIA
}

\section{I.1 - Ori em da e pressão Poder de Pol cia .}

\author{
Em sua obra clássica, “ ermenêutica e Aplicação do Direito”, o \\ sempre atual Carlos Maximiliano ensina que:
}

Não é possível manejar com desembaraço, aprender a fundo uma ciência que se relacione com a vida do homem em sociedade, sem adquirir antes o preparo propedêutico indispensável. ${ }^{16}$

É exatamente isto que nos proporemos a fazer neste capítulo, ou seja, buscar na história, narrada pela doutrina mais abalizada, os elementos necessários ao correto entendimento deste importante mecanismo posto a disposição do Estado.

Para tanto, começaremos pelas origens mais remotas do instituto.

Conforme veremos, o poder de polícia surgiu da necessidade de ordenação do convívio coletivo e se desenvolveu não somente acompanhando a evolução dos aglomerados urbanos e cidades, mas também em função da própria expansão dos direitos individuais e sociais, cumprindo sempre o papel primordial de preservar a estrutura social dos povos e a existência do próprio Estado. ${ }^{17}$

É comum entre os estudiosos ${ }^{18}$ apontar o Direito Norte Americano como origem da expressão "poder de polícia", onde o termo "Police Power" foi cunhado pela jurisprudência em $\operatorname{cases}^{19}$ em que as Cortes atuaram no sentido de reconhecer a limitação das liberdades individuais em favor da prevalência do interesse coletivo ${ }^{20}$.

\footnotetext{
${ }^{16}$ MAXIMilianO, Carlos, Hermenêutica e Aplicação do Direito, 19ª Ed., Ed. Forense, Rio de Janeiro, 2010 , p. 112.

${ }^{17}$ MEIRELLES, Hely Lopes, Direito Municipal Brasileiro, $12^{\mathrm{a}}$ ed., Malheiros Editores, São Paulo, 2001, p. 440.

${ }_{18}^{18}$ ARAÚJO, Edmir Netto de, Curso de Direito Administrativo, Saraiva, 5a Ed., São Paulo, 2010, p. 1045.

${ }^{19}$ Entre outros casos: Bibbons x Ogden (1814), Brown x Maryland (1827), Noble Bank x Haskell (1854) e na Inglaterra: Commonwealth x Alger (1954).

${ }^{20}$ Neste sentido: - CAVALCANTI, Themístocles Brandão, Princípios Gerais de Direito Administrativo, Editora Freitas Bastos, São Paulo, 1945, p. 424.
} 
Com base nos poderes residuais, os Estados-Membros americanos (EUA) passaram a desenvolver uma competência legislativa que tinha como função limitar os direitos privados em favor do interesse coletivo, o que caracterizava bem como o "Police Power" era compreendido no direito Norte-Americano. ${ }^{21}$

Muito embora o poder de polícia em geral sempre tenha existido, sendo mesmo inerente à ideia de Estado, a expressão que se difundiu por todo mundo foi empregada originalmente pelos magistrados americanos ${ }^{22}$, não tendo surgido antes de $1827 .^{23}$

Diferente dos países europeus, que se utilizavam da expressão poder de polícia tão somente vinculado a proteção da saúde, segurança e moralidade, nos Estados Unidos, o "Police Power" abrangia também os interesses econômicos e sociais, incluindo a atividade legislativa. ${ }^{24}$

Tal opinião, porém, não é unânime.

Para Bartolome Fiorini ${ }^{25}$, por exemplo, já na França do Século

IV a expressão "polícia" foi utilizada para designar as atividades do Estado, no seu sentido mais amplo. Neste período a polícia se reduzia a uma atividade municipal destinada a organização dos lugares públicos e das propriedades públicas, dando origem ao que se denominou "ordem pública".

A expressão também já teria sido utilizada na Alemanha do século $\mathrm{XV}$, que só excepcionou de sua abrangência as questões ligadas ao relacionamento internacional. $^{26}$

Já para Odete Medauar ${ }^{27}$, foi na França do século XVIII que apareceu primeiramente a expressão polícia, já ligada a ideia de "polícia administrativa", tendo sido utilizado no $3^{\circ}$ Brumário em 1795 (ano IV). Com efeito, o documento faz expressa menção a duas modalidades de polícia: a judiciária e a administrativa.

\footnotetext{
${ }^{21}$ TÁCITO, Caio, Poder de Polícia e Polícia do Poder, in: Direito Administrativo da Ordem Pública, (obr. Coletiva), $2^{\text {a }}$ ed., Editora Forense, Rio de Janeiro, 1987, p. 101

${ }^{22}$ CRETELla JR., José, Do Poder de Polícia, Rio de Janeiro, Forense, 1999, PP. 04 e 05.

${ }^{23}$ VASQUEZ, Ramon, Poder de Polícia, $2^{\mathrm{a}}$ ed., Buenos Aires, 1957, p. 26.

${ }^{24}$ PIRES, Luis Manuel Fonseca, Limitações Administrativas à Liberdade e à Propriedade, Quartier Latin, São Paulo, 2006, p. 148.

${ }^{25}$ FIORINI, Bartolome, Derecho Admnistrativo, Ed. Abeledo-Perrot, $2^{\mathrm{a}}$ edição atualizada, Abeledo-Perrot, Buenos Aires, 1976, p. 18.

${ }^{26}$ PIRES, Luis Manuel Fonseca, Limitações Administrativas à Liberdade e à Propriedade, Quartier Latin, São Paulo, 2006, pp. 137 e 138.

${ }^{27}$ MEDUAR, Odete, Poder de Polícia, in Boletim de Direito Administrativo, São Paulo, v. 12, no 12, p. 814-

9, dezembro de 1996, p. 815.
} 
Cabe aqui abrir um parêntesis para destacar o importante registro trazido pela autora citada no sentido de que no Brasil, a Constituição de 1824 já fazia menção a posturas municipais a serem exercidas pelas Câmaras Municipais; e uma Lei de 1 de janeiro de 1.828 já trazia a expressão "posturas policiais" referindo-se a estas atividades. Para ela, o pioneiro na utilização da expressão poder de polícia no direito brasileiro foi Rui Barbosa, em 1915, seguido por Aurelino Leal que, em 1.918 lançou o livro "Policia e Poder de Polícia", fixando a expressão no Direito pátrio. ${ }^{28}$

Retomando a linha de raciocínio, Eros Grau $^{29}$ também entende que foi na França que surgiu a expressão, porém, aponta para a Norma de 22.12.1789/8.1.1790 e para o Decreto d'Allarde, de 17.3.1791 como sendo o seu marco originário.

Uma vez fixada a expressão pelos franceses, sua utilização rapidamente se espalhou pelas "comunas" europeias, que passaram a empregar o poder de polícia do modo como o entendemos hoje, valendo registrar ainda que foram nestas comunidades que os administradores lançaram mão de instrumentos típicos de policia administrativa tais como: a licença para construir, a fiscalização de profissões, a polícia sanitária e outros próprios da vida urbana. ${ }^{30}$

Otto Mayer ${ }^{31}$, aliás, faz registro no mesmo sentido, consignando que foi na época do Renascimento que a ideia de polícia ganhou força em toda Europa, ligada ao controle das atividades praticadas nas cidades "y para la vida comunal", tendo tomado proporções de âmbito regional e nacional apenas com o início da era Moderna.

Edmir Netto de Araújo $^{32}$ ressalva, porém, que a expressão "polícia” advém de um período muito anterior, remontando ao período da Grécia antiga, onde a expressão polis que designava os agrupamentos urbanos da época (como as civitas romanas) deu origem a ideia de politeia ${ }^{33}$, ou atividade administrativa, donde derivou a palavra polícia.

Maria Sylvia Zanella Di Pietro ${ }^{34}$ caminha no mesmo sentido, identificando no radical grego politeia a origem da expressão "poder de polícia"35.

\footnotetext{
${ }^{28}$ MEDUAR, Odete, Direito Administrativo Moderno, $3^{\text {a }}$ ed., São Paulo, 1999, p. 365.

${ }^{29}$ GRAU, Eros Roberto, Poder de Polícia: Função Administrativa e Princípio da Legalidade: O Chamado “Direito Alternativo”, Revista Trimestral de Direito Público, n 01/1993, Editora Malheiros, p. 94.

${ }^{30}$ MEDUAR, Odete, Direito Administrativo Moderno, $3^{\mathrm{a}}$ ed., São Paulo, 1999, p. 365.

${ }^{31}$ MAYER, Otto, Derecho Administrativo Alemán, Ed. Depalma, Buenos Aires, 1950, pp. 03/04.

${ }^{32}$ ARAÚJO, Edmir Netto de, Curso de Direito Administrativo, Saraiva, 5a Ed., São Paulo, 2010, p. 1045.

${ }^{33}$ Manoel Gonçalves Ferreira Filho explica que: "Trata-se de um termo diretamente derivado do grego, para exprimir o que, nas traduções antigas, se designava por república.” (in: Princípios Fundamentais do Direito Constitucional, Saraiva, São Paulo, 2009, nota de rodapé 33, p. 13).

${ }^{34}$ DI PIETRO, Maria Sylvia Zanella, Direito Administrativo, Atlas, 20ª Ed., São Paulo, 2007, p. 102.
} 
Clóvis Beznos ${ }^{36}$ aponta a mesma origem para a expressão, enquanto Odete Medauar ${ }^{37}$ acrescenta como uma das origens remotas do termo, o radical latino politia e, em outra oportunidade faz alusão ao termo grego politeo, que também remete à ideia de polis. ${ }^{38}$

De fato, sua procedência do grego polis, que faz remissão à ideia de ordenação da cidade antiga, explica a estreita relação entre a policia e a Administração que se propagou até o fim da Idade Média. ${ }^{39}$

Caio Tácito vai ainda mais longe ao expressar que:

Etimologicamente, o vocábulo se confunde com a própria organização da comunidade. Polícia (do grego politéia, por intermédio do latim politia) equivale à administração da cidade (polis) ${ }^{40}$.

De fato, conforme verificaremos, as noções de policia e de Estado se confundiram em muitos momentos da história, o que por si só já deixa entrever a importância do estudo deste tema para o Direito, em especial para o Direito Administrativo.

Na busca pelo correto entendimento da matéria, começaremos por examiná-la justamente naquele que é apontado como seu ponto de partida, a Grécia antiga.

\section{I.2 - O Poder de Polícia na Grécia.}

Logo de partida, é preciso fazer uma importante elucidação. A despeito de todos os autores identificarem na Grécia antiga as origens remotas do "poder de polícia" ou ao menos da expressão "policia", na verdade, o termo politia para os helênicos possuía um sentido completamente diferente do que fora assumido posteriormente pela atividade estatal ora em exame.

\footnotetext{
${ }^{35}$ No mesmo sentido: CASSAGNE, Juan Carlos, Derecho Administrativo, $6^{\text {a }}$ Ed., Abeledo-Perrot, Buenos Aires, 2000, p. 451.

${ }^{36}$ BEZNOS, Clóvis, Poder de Polícia, Revista dos Tribunais, São Paulo, 1979, p. 1.

${ }^{37}$ MEDUAR, Odete, Direito Administrativo Moderno, $3^{a}$ ed., São Paulo, 1999, p. 364.

${ }^{38}$ MEDUAR, Odete, Poder de Polícia, in Boletim de Direito Administrativo, São Paulo, v. 12, no 12 , p. 8149, dezembro de 1996.

${ }^{39}$ MOREIRA NETO, Diogo de Figueiredo, Curso de Direito Administrativo, $15^{\text {a }}$ ed., Ed. Forense, 2009, p. 441.

${ }^{40}$ TÁCITO, Caio, Temas de Direito Público (Estudos e Pareceres), Renovar, Rio de Janeiro, 1997, p. 521.
} 
A expressão "politeia" designava à época o conjunto de todas as atividades desenvolvidas pelo Estado na "Polis". A ideia de politeia abrangia todo o ordenamento político do Estado, ou seja, o governo em seu sentido mais lato. ${ }^{41}$

Nas cidades-estados da Grécia, política e polícia eram noções inseparáveis. O termo politéia aglutinava todas as atividades administrativas das cidadesestados, sendo certo que somente muito tempo depois é que as funções do Estado foram distinguidas ${ }^{42}$.

Neste período, tudo pertencia a polis, inclusive o próprio cidadão. Tudo estava à disposição do Estado, não havendo nada imune à intromissão estatal, nem mesmo a privacidade. O Estado determinava como se vestir, como se comportar, no que se ocupar, chegando ao extremo de haver leis proibindo o cidadão de se barbear, ou de beber vinho, por exemplo. ${ }^{43}$

A ausência de separação entre o público e o privado fazia com que o poder do Estado, exercido nas polis grega, se imiscuísse em todas as esferas, mesmo as mais restritas, até mesmo nos sentimentos afetivos. $\mathrm{O}$ direito e a atividade policial grega eram totalmente difusos, marcados pela intromissão nas mais insignificantes atividades particulares $^{44}$.

De fato, na Grécia antiga o homem não desfrutava qualquer liberdade, não se podendo aludir a qualquer direito individual. $\mathrm{O}$ homem vivia para o Estado e se realizava nele. Só tinha valor enquanto ligado à comunidade, como membro dela, encontrando nela sua identidade. ${ }^{45}$

Cumpre mesmo ressalvar que a própria noção de que a Grécia antiga foi o "berço da democracia" deve ser adotada com reservas, pois a verdade é que o exercício democrático praticado à época em muito pouco se assemelhava ao conceito moderno de democracia.

\footnotetext{
${ }^{41}$ BEZNOS, Clóvis, Poder de Polícia, Revista dos Tribunais, São Paulo, 1979, p. 01.

42 PIRES, Luis Manuel Fonseca, Limitações Administrativas à Liberdade e à Propriedade, p. 134.

${ }^{43}$ BEZNOS, Clóvis, Poder de Polícia, Revista dos Tribunais, São Paulo, 1979, p. 03.

${ }^{44}$ FIORINI, Bartolome, Poder de Polícia, Editora Alfa, Buenos Aires, 1962, p. 27.

${ }^{45} \mathrm{O}$ filósofo e ex-ministro de educação da França, Luc Ferry, ensina que para o grego da época " $a$ identidade de uma pessoa passa por três pontos cruciais, sendo o primeiro a sua identidade em uma comunidade harmoniosa-um cosmos. Uma vez mais, o homem só é de fato homem entre os homens e, em exílio, ele nada é - por isso, aliás, o banimento da cidade, para os gregos, corresponde a uma condenação à morte, o castigo supremo que se inflige aos criminosos". (In: A Sabedoria dos Gregos - Aprender a Viver II Objetiva, Rio de Janeiro, 2.009, pp. 145 e 146).
} 
Conforme a lição de Sahid Maluf:

O próprio Estado ateniense, no auge da sua glória, sob a liderança de Péricles, apresentava, na sua população de meio milhão de habitantes, cerca de $60 \%$ de escravos, sem direitos políticos de qualquer espécie, além de cerca de 20.000 estrangeiros. Resumiam-se a pouco mais de 40.000 os cidadãos que governavam Atenas e constituíam a soberania do Estado. $^{46}$

Não havia entre os gregos a preocupação de equacionar o interesse individual com o bem comum, uma vez que o indivíduo não passava de mais um dos bens da polis.

O homem na antiga polis grega não possuía qualquer valor senão como integrante da coletividade. Não possuía valor individual. A noção de policia só se referia às necessidades da coletividade. A coletividade era a cidade. $\mathrm{O}$ cidadão era simples elemento da polis, sem personalidade. Os gregos guardavam um sentido harmonioso de unidade da polis, que era característica cultural, porém, a vontade pessoal era quase totalmente alijada. ${ }^{47}$

Os cidadãos helênicos viviam de forma privilegiada e tinham suas necessidades quase todas satisfeitas pela polis e pelo trabalho dos escravos, não considerados, como vimos, seus membros.

Portanto, não havia que se falar em conformação de um direito que o indivíduo sequer suspeitava possuir, razão pela qual, muito embora o termo "polícia" guarde relação com a politeia grega, tal relação limita-se à sua etimologia/morfologia, não possuindo ligação do ponto de vista da hermenêutica jurídica.

Neste sentido Clóvis Beznos ensina que:

...o grego da Cidade-Estado não tinha, efetivamente, a menor noção da liberdade individual, donde se conclui ser inconcebível em tal época a noção jurídica de polícia administrativa, como hoje a compreendemos. ${ }^{48}$

\footnotetext{
${ }^{46}$ MALUF, Sahid, Teoria Geral do Estado, $28^{\circ}$ ed., Saraiva, São Paulo, 2008, p. 105.

${ }^{47}$ FIORINI, Bartolome, Poder de Polícia, Editora Alfa, Buenos Aires, 1962, pp. 25 e 26.

${ }^{48}$ BEZNOS, Clóvis, Poder de Polícia, Revista dos Tribunais, São Paulo, 1979, p. 06
} 
Percebe-se, portanto, que a expressão polícia, em sua origem, em nada se assemelha a acepção moderna do termo, uma vez que na Grécia, direitos individuais não eram levados em conta. ${ }^{49}$

Eventual direito privado ligado a atividades patrimoniais era relegado a um segundo plano. O equilíbrio entre o interesse coletivo e o indivíduo não tinha qualquer sentido, pois, tal relação simplesmente não existia, razão pela qual Fiorini conclui que:

\footnotetext{
"los pueblos griegos no han podido legar nada al pensiamiento jurídico moderno sobre la función policial, salvo la discutibilidad de su término ${ }^{50}$."
}

A despeito da contundência da afirmação, pondera-se que, apesar de a polis grega catalisar todas as necessidades dos indivíduos e satisfazê-las física e espiritualmente, a guerra com outros povos e o atrito com os escravos fez surgir a necessidade de um certo "poder de polícia", fazendo crer que é equívoca a afirmação de que os gregos desconheciam totalmente os direitos individuais. $\mathrm{Na}$ verdade, progressivamente estes direitos individuais foram se introduzindo na sociedade grega.

Fato é que a influência dos estoicos colaborou para que surgissem algumas garantias individuais reconhecidas pela cidade. Com o tempo foi estabelecida alguma segurança individual, em razão do desenvolvimento comercial de Atenas e o surgimento de alguma produção artesanal, que remetem à existência de um embrião do direito individual. $^{51}$

\section{I.3 - O Poder de Polícia em Roma.}

Diferentemente do que ocorreu com os gregos, os romanos realmente experimentaram as primeiras noções do poder de polícia do modo como o compreendemos hodiernamente, muito embora, é claro, dentro do contexto da época. ${ }^{52}$

\footnotetext{
${ }^{49}$ PIRES, Luis Manuel Fonseca, Limitações Administrativas à Liberdade e à Propriedade, Quartier Latin, São Paulo, 2006, p. 135.

${ }^{50}$ FIORINI, Bartolome, Poder de Polícia, Editora Alfa, Buenos Aires, 1962, p. 28.

${ }^{51}$ FIORINI, Bartolome, Poder de Polícia, Editora Alfa, Buenos Aires, 1962, pp. 26 e 27.

52 Conforme registra Sahid Maluf: "O Estado romano, muito semelhante ao Estado grego, tinha suas características peculiares: distinguia o direito da moral, limitando-se à segurança da ordem pública; a propriedade privada era um direito quiritário que o Estado tinha empenho em garantir; o homem gozava de
} 
É fato que as cidades romanas sob muitos aspectos se assemelhavam as polis gregas. Porém, o grande desenvolvimento do império romano, sua riqueza e a grande quantidade de escravos deram causa ao surgimento de um legado até hoje utilizado, qual seja, a separação entre o direito público "jus publicus" e o privado "jus privatus".

Tal divisão tornou-se necessária a partir do momento em que se identificaram em favor do Estado, bens e direitos distintos aos dos particulares. Neste período, há um reconhecimento da figura do indivíduo que, em razão do desenvolvimento de suas atividades e da acumulação de riquezas, acaba produzindo e reafirmando o direito privado, distinto do âmbito público. ${ }^{53}$

A noção de propriedade expandiu ao ponto de impor-se a necessidade de restringi-la. Tal restrição foi exercida pelo direito público através de autoridades judiciais ou por meio de autoridades públicas. ${ }^{54}$

Com efeito, o desenvolvimento das ciências jurídicas e o fortalecimento da noção de propriedade privada em contraposição a publica, fizeram com que o Estado impusesse limitações àquelas (propriedades privadas) com base no exercício de uma função que atuasse para o estabelecimento do interesse público - a polícia administrativa.

A distinção do direito público em relação ao direito privado em Roma está, portanto, na base de sua construção jurídica e a polícia administrativa foi o instrumento utilizado para fazer prevalecer o direito público, muito embora com ênfase maior na propriedade do que em relação à pessoa do proprietário. ${ }^{55}$

$\mathrm{O}$ respeito aos negócios entre particulares e à propriedade fez brotar ainda a noção de que o prometido deveria ser cumprido, restando a um magistrado a função de zelar para que isso ocorresse. ${ }^{56}$

Surgiu ainda a noção de direito adquirido, como expressão da realização do direito subjetivo que se realizou de modo completo (perfeito). O direito

relativa liberdade em face do poder estatal, não sendo obrigado, praticamente, a fazer ou deixar de fazer alguma coisa senão em virtude de lei; o Estado era havido como nação organizada; a vontade nacional era fonte legítima do Direito.” MALUF, Sahid, Teoria Geral do Estado, $28^{\circ}$ ed., Saraiva, São Paulo, 2008, p. 111).

${ }^{53}$ FIORINI, Bartolome, Poder de Polícia, Editora Alfa, Buenos Aires, 1962, pp. 28 e 29.

${ }^{54}$ BEZNOS, Clóvis, Poder de Polícia, Revista dos Tribunais, São Paulo, 1979. p. 6 e 7.

${ }^{55}$ PIRES, Luis Manuel Fonseca, Limitações Administrativas à Liberdade e à Propriedade, Quartier Latin, São Paulo, 2006, p. 135.

${ }^{56}$ BEZNOS, Clóvis, Poder de Polícia, Revista dos Tribunais, São Paulo, 1979, pp. 30 e 31. 
romano confere ao indivíduo o direito de conquistar riquezas e impõe ao Estado o dever de respeitar a riqueza particular adquirida na forma permitida.

Em razão deste respeito do direito romano pelo direito adquirido e pelas atividades lucrativas dos indivíduos, ganhou força e importância a função policial de conotação jurídica. Na verdade o reconhecimento dos direitos individuais representava a afirmação do próprio império em toda sua extensão.

Também nesta época, surgiu entre os romanos a necessidade de regulação dos espaços entre os prédios das "citadinas", restringindo o direito que tinham os proprietários de abrir janelas voltadas para a propriedade vizinha ou de obstruir as janelas destes. Com Justiniano (final do Século V início do VI), afloraram diversas limitações à propriedade com vistas à prevalência do interesse coletivo, deixando estampado que a noção de poder de polícia já marcava presença entre os romanos, num verdadeiro ensaio do que hoje conhecemos por direito urbanístico.

Vale registrar que por uma questão política, foram concedidos às províncias conquistadas (municípios) alguns benefícios tais como a liberdade e a magistratura, entre outros, sendo certo que estes municípios desempenhavam suas funções internas através de indivíduos eleitos, com destaque para os "ediles", que exerciam o poder de polícia. ${ }^{57}$

Em Roma, a função policial foi exercida também com o objetivo de proteger o particular da força esmagadora dos credores e das atividades que eram exercidas de forma a provocar exagerado aumento do preço das mercadorias. Neste contexto sugiram limitações ao preço do trigo e leis que limitavam a compra de terras com a finalidade de se evitar a formação de oligarquias. ${ }^{58}$

Porém, tanto Fiorini ${ }^{59}$ como Beznos $^{60}$ ressalvam que este alto grau de exercício do direito privado, ao ponto de provocar sua limitação através do poder de polícia, restringiu-se a denominada "época de ouro do Império Romano" ${ }^{61}$, sendo certo que após este período tais direitos foram sufocados pela arbitrariedade.

Assim como a Grécia, Roma também teve seus altos e baixos, como no período de Constantino (306 a 337 d.C.), em que aflorou o despotismo, fazendo com que desaparecesse a esfera de direito privado. Em detrimento, porém, de todos os

\footnotetext{
${ }^{57}$ BEZNOS, Clóvis, Poder de Polícia, Revista dos Tribunais, São Paulo, 1979, pp. 8 e 9.

${ }^{58}$ FIORINI, Bartolome, Poder de Polícia, Editora Alfa, Buenos Aires, 1962, p. 32.

${ }^{59}$ FIORINI, Bartolome, Poder de Polícia, Editora Alfa, Buenos Aires, 1962, p. 33.

${ }^{60}$ BEZNOS, Clóvis, Poder de Polícia, Revista dos Tribunais, São Paulo, 1979, pp. 10 e 11.

${ }^{61}$ Mais ou menos até o ano 180 d.C., com a morte de Marco Aurélio.
} 
problemas romanos, a função policial se firmou como ponto de equilíbrio entre o indivíduo e o bem comum.

Certo é que, apesar das oscilações, o direito romano insculpiu o poder de polícia como instrumento para imposição de um ponto de equilíbrio entre os interesses individuais e os interesses coletivos.

\section{I.4 - O Poder de Polícia na Idade Média.}

Tida por diversos historiadores como uma época de total obscurantismo e ignorância, a Idade Média ou "Período Feudal" tem início no século V com a Queda do Império Romano do Ocidente e se estendeu até ao século XV com o Renascimento Cultural e a Expansão Marítima.

Neste período, de modo geral, não eram reconhecidos direitos individuais. É bem verdade que os senhores feudais, que exerciam o poder de polícia, reconheciam alguns direitos aos seus pares e súditos, mas apenas porque, sem o reconhecimento de um mínimo de direitos não haveria ordem.

Como o poder de polícia abrangia neste período todas as ações estatais, pretensamente visando o bem estar da comunidade e a garantia da segurança, é certo dizer que na Idade Média, as noções de Estado e polícia são inseparáveis. ${ }^{62}$ Só não estavam abrangidos na noção de polícia os aspectos ligados aos conceitos de moral e religião, assuntos adstritos aos domínios da Igreja ${ }^{63}$.

Através da polícia era mantida a ordem num ambiente desigual, sem que fosse levada em conta a vida das pessoas. Os indivíduos faziam parte dos vários feudos, onde viviam segundo a "vontade divina". Como a condição de vida era imposta de forma fatalista, pela vontade superior, o individuo não possuía um valor absoluto para justificar uma relação de equilíbrio. As vontades particulares, na verdade, estavam submetidas à vontade divina. Tudo estava a serviço da vontade divina ${ }^{64}$

Neste período viceja o denominado "ius policei", voltado a regular o que fosse necessário à ordem pública. A noção de polícia compreendia a atuação da autoridade do Estado, sem qualquer limitação na busca pela ordem social, só não

\footnotetext{
${ }^{62}$ FERREIRA, Daniel, Poder de Polícia, in Curso de Direito Administrativo, Marcelo Harger (org.) Ed. Forense, Rio de Janeiro, 2007, p. 354.

${ }^{63}$ CASSAGNE, Juan Carlos, Derecho Administrativo, 6a Ed., Abeledo-Perrot, Buenos Aires, 2000, p. 451.

${ }^{64}$ FIORINI, Bartolome, Poder de Polícia, Editora Alfa, Buenos Aires, 1962, pp. 34/35.
} 
abrangendo, como já dissemos, as questões atinentes à moral e à religião, adstritas às autoridades sacras. $^{65}$

O poder de Deus era representado na terra pela figura do Papa, que exercia seu poder sobre as coisas religiosas e aceitava que os príncipes se ocupassem com as questões temporais, se tornando representantes dos Papas nestes assuntos. Neste contexto, o valor do indivíduo comum era nulo, sendo certo que sequer dispunha sobre sua vontade.

Para a Igreja da época, a figura do particular se diluía na órbita geral, em cumprimento a vontade divina, pois todo ato do poder público representa a vontade de Deus. Considerava-se o bem comum a sustentação da ordem estabelecida e a atividade policial servia como instrumento de manutenção da ordem revelada por Deus. O indivíduo não era tido como unidade consciente. ${ }^{66}$

Foi neste período que surgiu a expressão jus politiae usada justamente para designar os poderes do príncipe. A mesma expressão (jus politiae) foi utilizada posteriormente na Alemanha no Século XV, ainda aludindo aos poderes do príncipe. ${ }^{67}$

Figura marcante do exercício do poder de polícia neste período (já em meados do século XI) foi a do xerife, autoridade administrativa criada pelo Duque Guilherme na Inglaterra, para controlar os senhores feudais, os comerciantes e os camponeses dentro de regi es denominadas "Shires" ou condados, onde exercia o poder de polícia, por delegação do rei, inclusive para a cobrança de impostos. ${ }^{68}$

Do “jus politiae”, exercido na Idade Média pelo príncipe, abrangendo toda a atividade de ordenação do convívio social, evoluiu-se no Século XV para a ideia de polícia que, para os germânicos, muito embora significasse toda a atividade do Estado, era dividida entre Administração da Justiça e a Administração em geral. ${ }^{69}$

A despeito desta situação de absoluta submissão dos indivíduos, a idade média é marcada pela aspiração do homem por uma unidade harmoniosa e pelo anseio de liberdade. A idade média se destaca como período onde germinam valores e contradições que abrem caminho para grandes transformações sociais. ${ }^{70}$

\footnotetext{
${ }^{65}$ BEZNOS, Clóvis, Poder de Polícia, Revista dos Tribunais, São Paulo, 1979, pp. 13/14.

${ }^{66}$ FIORINI, Bartolome, Poder de Polícia, Editora Alfa, Buenos Aires, 1962, p. 36.

${ }^{67}$ DI PIETRO, Maria Sylvia Zanella, Direito Administrativo, Atlas, 20 a Ed., São Paulo, 2007, p. 102.

${ }^{68}$ LOYN, Henry R., Dicionário da Idade Média, Jorge Zahar Editor Ltda., Rio de Janeiro, 1997, p. 130.

${ }^{69}$ ARAÚJO, Edmir Netto de, Curso de Direito Administrativo, Saraiva, 5 a Ed., São Paulo, 2010, p. 1045.

${ }^{70}$ FIORINI, Bartolome, Poder de Polícia, Editora Alfa, Buenos Aires, 1962, p. 37.
} 


\section{I.5 - O Estado de Pol cia .}

A ideia de "Estado de Polícia" está diretamente ligada às monarquias absolutas, período no qual, como vimos, a função de polícia estava vinculada ao exercício da soberania do rei.

É no Século VIII que ganha força o "Estado de Polícia", caracterizado pela intensa intervenção do Estado na vida privada dos indivíduos.

O "Estado de Polícia" é caracterizado pelo exercício de uma autoridade que não conhece limites ou regras, num ambiente em que o indivíduo não tem qualquer reconhecimento, não se podendo falar em direitos individuais comuns. A figura central, o príncipe, era dono e senhor dos bens comuns e qualquer ato seu era tomado como que na busca do bem comum.

Conforme registrou Cassagne:

"A partir de la Edad Moderna, con el auge de las ideas del nominalismo y de las filosofias que continuaron esa corriente se produjo uma sustancial mutación en los fines de los gobiernos sustituyéndose el bien común por la razón de Estado ejercida por um poder que se concebia soberano, absoluto e ilimitado.,"71

Neste período, a atividade de polícia era a mais ampla possível, uma vez que não eram reconhecidos limites a ela. Não se impunham os direitos patrimoniais ou pessoais frente aos poderes do príncipe. O que se buscava, na verdade, não era o bem da cidade ou mesmo do império, mas o do próprio príncipe como ser supremo, dono e senhor de todas as coisas.

O poder de polícia era tido como uma prerrogativa jurídica ilimitada de impor ordens e agir da forma julgada mais conveniente pelo soberano, não encontrando qualquer limitação quanto aos meios ou quanto à finalidade para a qual estava destinada a conduta administrativa. ${ }^{72}$

${ }^{71}$ CASSAGNE, Juan Carlos, Derecho Administrativo, $6^{\text {a }}$ Ed., Abeledo-Perrot, Buenos Aires, 2000, p. 452.

${ }^{72}$ GORDILLO, Augustin A., Tratado de Derecho Administrativo, Parte Geral - Tomo II, Editores MacchiLopez, Buenos Aires, 1975, p. 04. 
Como representante de Deus, as atitudes do príncipe estavam teologicamente justificadas, pois não há liberdade ou direito contra a vontade divina. ${ }^{73}$ Assim, os poderes do monarca, a despeito de serem exercidos a pretexto de garantir o bem estar comum, por não estarem sujeitos a aferição pelo judiciário, eram exercidos ao talante do mandatário. ${ }^{74}$

A polícia era imposta na prática por um corpo de agentes administrativos armados que, para garantir a ordem social, realizavam atos com força igual a do exército. ${ }^{75}$ Todas as atividades para manutenção da "ordem social" no "Estado de Polícia" eram manifestaç es da vontade soberana do rei, impingidas de modo arbitrário e unilateral. A polícia neste período era, na verdade, a expressão da força do próprio príncipe. $^{76}$

Nesta época os assuntos de polícia eram tratados pelo próprio monarca, sem que os indivíduos tivessem direito a qualquer forma de recurso, não lhes sendo viável nem mesmo o acesso a Justiça para se proteger do despotismo. Tal cenário, permeado pela arbitrariedade e pelo abuso do poder, imprimiu à expressão: "Estado de Polícia”, um sentido fortemente pejorativo. ${ }^{77}$

Este foi o período histórico em que mais foram desprezados os direitos e aspirações individuais, só se atribuindo valor a vontade do soberano. Tão contundentes eram os poderes do príncipe que, como tentativa de reação, surgiu, por exemplo, a denominada "Teoria do Fisco", segundo a qual os bens públicos não eram considerados propriedade do príncipe ou do Estado, mas do Fisco, e eram regidos pelo direito privado. Visava a "Teoria do Fisco" de alguma forma controlar os poderes do príncipe e até certo ponto responsabilizá-lo por seus atos. ${ }^{78}$

Paulatinamente o poder do rei foi deixando de ter justificativa exclusivamente na vontade divina, passando a justificar-se pela utilidade pública de se atender a vontade do soberano. Tal doutrina foi denominada "Razão de Estado" e na prática, também validava qualquer ato do príncipe.

\footnotetext{
${ }^{73}$ FIORINI, Bartolome, Poder de Polícia, Editora Alfa, Buenos Aires, 1962, pp. 37/39.

${ }^{74}$ DI PIETRO, Maria Sylvia Zanella, Direito Administrativo, Atlas, 20ª Ed., São Paulo , 2007, p. 102.

${ }^{75}$ FIORINI, Bartolome, Derecho Admnistrativo, Ed. Abeledo-Perrot, $2^{\text {a }}$ edição atualizada, Abeledo-Perrot, Buenos Aires, 1976, p. 19.

${ }^{76}$ PIRES, Luis Manuel Fonseca, Limitações Administrativas à Liberdade e à Propriedade, Quartier Latin, São Paulo, 2006, p. 139.

${ }^{77}$ BEZNOS, Clóvis, Poder de Polícia, Revista dos Tribunais, São Paulo, 1979, p.15.

${ }^{78}$ PIRES, Luis Manuel Fonseca, Limitações Administrativas à Liberdade e à Propriedade, Quartier Latin, São Paulo, 2006, pp. 140 e 141
} 
A atividade do príncipe, voltada a governar e satisfazer a "vontade do povo", acabou recebendo o nome de "política" e compreendia tanto a defesa do Estado quanto o bem da comunidade. Esta atividade que a princípio visava na verdade a afirmação do príncipe contra os poderes da igreja e da nobreza transformou-se gradativamente na atividade de defesa do interesse das cidades, nos moldes como ocorrera na polis, porém, com o exercício concentrado na figura do soberano. ${ }^{79}$,

Mencionando as lições de Garrido Falla, Clóvis Beznos ${ }^{80}$ destaca que se notavam nas leis alemãs deste período (século XVIII), relativas à polícia administrativa, um traço marcante, qual seja a previsão de imposição coativa de seus ditames. Em razão desta característica (coerção), entendeu-se que atividades do Estado de cunho social ou de fomento não estavam abrangidas na noção de polícia nesta fase.

Com o passar do tempo, já no final do século XVIII, o "Estado de Polícia" era exercido fundamentalmente para combater as condutas que fossem lesivas a paz e ao bem estar da coletividade, num momento em que ganhavam força as atividades de comércio entre os feudos. ${ }^{81}$

Foi neste movimento que gradativamente os poderes foram perdendo sua discricionariedade absoluta e aproximando-se do Estado de Direito, sob a forte influência do liberalismo, num ensaio de aproximação das ações estatais ao princípio da legalidade. ${ }^{82}$

\footnotetext{
${ }^{79}$ FIORINI, Bartolome, Poder de Polícia, Editora Alfa, Buenos Aires, 1962, pp. 40 e 41.

${ }^{80}$ BEZNOS, Clóvis, Poder de Polícia, Revista dos Tribunais, São Paulo, 1979, pp. 15 e 16.

${ }^{81}$ FIORINI, Bartolome, Poder de Polícia, Editora Alfa, Buenos Aires, 1962, p. 41.

${ }^{82}$ ARAÚJO, Edmir Netto de, Curso de Direito Administrativo, Saraiva, 5a Ed., São Paulo, 2010, pp. 1045 e 1046.
} 


\section{II - A NOÇÃo CLÁSSICA DO PODER DE POLÍCIA.}

Realizada a análise do poder de polícia sob o ponto de vista histórico, cumpre-nos apresentar neste capítulo a forma como restou sedimentado o tema na doutrina clássica.

Vale enfatizar neste momento que a designação "doutrina clássica" aqui utilizada, não sugere de forma alguma uma doutrina antiga ou ultrapassada. Muito pelo contrário, o que denominamos "doutrina clássica" corresponde justamente ao posicionamento dos doutrinadores que vêm construindo a estrutura moderna do pensamento sobre o tema poder de polícia e que, por seu peso acadêmico, deram forma ao instituto como o conhecemos hoje.

É partindo da sólida base dos conceitos e características formulados por esta doutrina, que poderemos nos habilitar a ponderar sobre a consistência das mesmas, avaliar as principais críticas que lhes são contrapostas para então, no capítulo seguinte, procurar descortinar os novos vieses desta função pública de relevância indiscutível.

De um modo geral, portanto, a doutrina clássica corresponde justamente à ideia comum sedimentada que se tem sobre o poder de polícia, conforme passaremos a expor.

\section{II.1 - Conceitos.}

Já é sólida a noção segundo a qual uma das atribuições precípuas do Estado é a de intervir na vida privada na busca de implementar o bem comum. Gabino Fraga, em sua obra clássica já ensinava que:

"Si el Estado interviene regulando juridicamente esa actividad es porque los interesses individuales necesitan ser coordinados a fin de mantener el orden jurídico., ${ }^{, 83}$

Esta é em geral, a noção de poder de polícia que se sedimentou com o enraizamento dos ideais liberais pós Revolução Francesa e Americana.

${ }^{83}$ FRAGA, Gabino, Derecho Administrativo, Porrúa, México, 1968, p. 07. 
Analisando este fenômeno, Caio Tácito retrata de forma hialina o pensamento clássico:

Na ordem nova da sociedade, retratada nas Declarações de Direito, o Estado opera, unicamente, como fator de equilíbrio nos conflitos entre direitos individuais superiormente protegidos nas Constituições. À autoridade cabe somente um papel negativo, de evitar a perturbação da ordem e assegurar a livre fruição dos direitos de cada um.

Esta competência de arbitragem caracteriza o conceito clássico do poder de polícia, simples processo de concentração de excessos do individualismo. O poder de polícia consiste, em suma, na ação da autoridade pública para fazer cumprir a todos os indivíduos o dever de não perturbar. ${ }^{84}$

A despeito da clareza desta visão, que de certa forma perdura até os nossos dias, a conceituação de poder de polícia não é - como poderia parecer a princípio uma tarefa das mais fáceis. ${ }^{85}$

Já de início há que se ponderar que existe uma diferença conceitual sobre a abrangência do poder de polícia entre os europeus e os norte-americanos. Para aqueles, o poder de polícia está adstrito a proteção imediata da ordem pública enquanto que para estes, o conceito de poder de polícia tem uma conotação ampla, englobando as mais diversas áreas da vida em sociedade, o que, como veremos mais adiante, aproximasse mais da ideia atual sobre o poder de policia. ${ }^{86}$

A conotação que os americanos dão aos poderes de polícia estende-se para além da simples manutenção da segurança, salubridade e moralidade, alcançando as ordens econômicas e sociais, inclusive com ações de fomento e regulamentação de atividades econômicas. ${ }^{87}$ Nos Estados nidos a expressão "Police Power" designa de forma especial a legislação pela qual o Estado regula as liberdades em favor do interesse coletivo ${ }^{88}$.

${ }^{84}$ TÁCITO, Caio, Poder de Polícia e Polícia do Poder, in: Direito Administrativo da Ordem Pública, (obr. Coletiva), $2^{\text {a }}$ ed., Editora Forense, Rio de Janeiro, 1987, p. 98.

${ }^{85}$ CRETELLA JR., José, Direito Administrativo Brasileiro, Editora Forense, 2a edição, Rio de Janeiro 2.000, p. 546.

${ }^{86}$ ARAÚJO, Edmir Netto de , Curso de direito Administrativo, Saraiva, 5 a Ed., São Paulo, 2010, p. 1046.

${ }^{87}$ CRETELLA JR., José, Direito Administrativo Brasileiro, Editora Forense, $2^{\mathrm{a}}$ edição, Rio de Janeiro 2.000 , p. 547.

${ }^{88}$ No mesmo sentido: FERREIRA, Daniel, Poder de polícia, in Curso de Direito Administrativo, Marcelo Harger (org.) Ed. Forense, Rio de Janeiro, 2007, p. 356. 
No Brasil, o conceito de poder de polícia aproximou-se mais da noção norte-americana, sendo amplo o espectro de sua abrangência, estabelecendo limites e mecanismos de atuação para as mais diversas atividades. ${ }^{89}$

Esta perspectiva mais abrangente do conceito de poder de polícia já podia ser observada no posicionamento de Jorge Miranda para quem:

É desacertado distinguir entre actos de criação e actos de aplicação do Direito. Com efeito, se deixarmos de lado os casos-limite - a pressuposição da norma fundamental e a execução do acto coercivo entre os quais se desenvolve o processo jurídico, todo o acto jurídico é simplesmente aplicação de uma norma superior e produção, regulada por esta norma, de uma norma inferior. ${ }^{90}$

Maria Sylvia Zanella Di Pietro, para demonstrar o caráter abrangente como é tomado o poder de polícia no Brasil, ensina que tal atividade é dividida entre o Legislativo e o Executivo, de forma que o Legislativo:

...no exercício do poder de polícia que incumbe ao Estado, cria, por lei, as chamadas limitações administrativas ao exercício das atividades públicas e indica as medidas de policia cabíveis para impor o seu cumprimento; enquanto a Administração: no exercício da parcela que lhe é outorgada do mesmo poder, regulamenta as leis e controla a sua aplicação... ${ }^{91}$

Colocada esta diferenciação, há que se levar em conta que para parte da doutrina brasileira clássica, a expressão poder de polícia pode ser tomada de uma forma ampla, mas no sentido de abranger a legislação que regula os direitos e liberdades, e de forma restrita, através da qual se refere aos atos do Poder Executivo exercidos com a mesma finalidade, podendo ser abstratos ou concretos. Para o professor Celso Antônio Bandeira de Mello, aliás, somente estes últimos podem ser tomados como atos de: "polícia administrativa". 92

\footnotetext{
${ }^{89}$ ARAÚJO, Edmir Netto de, Curso de Direito Administrativo, Saraiva, 5 Ed., São Paulo, 2010, p. 1046.

${ }^{90}$ MIRANDA, Jorge, Funções, Órgãos e Atos do Estado, Universidade de Lisboa, 1990, p. 14.

${ }^{91}$ DI PIETRO, Maria Sylvia Zanella, Poder de Polícia em Matéria Urbanística, in Temas de Direito Administrativo, Publicação conjunta, Ministério Público de São Paulo/Imprensa Oficial, São Paulo, 1999, p. 25 .

${ }^{92}$ BANDEIRA DE MELlo, Celso Antônio, Curso de Direito Administrativo, Malheiros, $21^{\text {a }}$ Ed., São Paulo, 2006, p. 780.
} 
Posto sob esta ótica, o poder de polícia pode ser tomado em primeiro lugar em sentido amplo, ou seja, aquele poder conferido pela Constituição para estabelecer, de forma abstrata, "normas de polícia". Tais restrições são veiculadas por meio de lei justamente para que não seja ferido o princípio da legalidade que garante que ninguém será obrigado a fazer ou deixar de fazer alguma coisa, senão em virtude de lei.

Em contraposição, decorrente do exercício deste poder de polícia em abstrato (amplo) é que se estabelecem os limites da atividade de polícia administrativa que é exercido pelo Poder Público (Executivo) de forma concreta, mediante atos de polícia administrativa, visando estabelecer limites aos particulares e dar efetividade aos interesses coletivos. $^{93}$

Em consonância com estas perspectivas encontramos na doutrina clássica os seguintes conceitos:

Hely Lopes Meirelles vai direito ao ponto quando declara que o poder de polícia é:

... o mecanismo de frenagem de que dispõe a Administração Pública para conter os abusos do direito individual. ${ }^{94}$

Para Celso Antônio Bandeira de Mello o poder de polícia é conceituado como:

\begin{abstract}
Atividade da Administração Pública, expressa em atos normativos ou concretos, de condicionar, com fundamento em sua supremacia geral e na forma da lei, a liberdade e a propriedade dos indivíduos, mediante ação ora fiscalizadora, ora preventiva, ora repressiva, impondo coercitivamente aos particulares um dever de abstenção "non facere" a fim de conformar-lhes os comportamentos aos interesses sociais consagrados no sistema normativo. ${ }^{95}$
\end{abstract}

\footnotetext{
${ }^{93}$ PESTANA, Márcio, Direito Administrativo Brasileiro, Campus Jurídico, Rio de Janeiro, 2008, p. 491.

${ }^{94}$ MEIRELLES, Hely Lopes, Direito Municipal Brasileiro, $12^{\mathrm{a}}$ ed., Malheiros Editores, São Paulo, 2001, p. 440.

95 BANDEIRA DE MELlo, Celso Antônio, Curso de Direito Administrativo, Malheiros, 21 a Ed., São Paulo, 2006, p. 795.
} 
Ainda segundo o mesmo autor, o poder de polícia é:

A atividade estatal de condicionar a liberdade e a propriedade ajustandoas aos interesses coletivos designa-se "poder de polícia. ${ }^{96}$

Clóvis Beznos, por sua vez ensina que:

Polícia administrativa é a atividade administrativa exercida sob previsão legal, com fundamento numa supremacia geral da Administração, e que tem por objeto ou reconhecer os confins do direitos, através de um processo, meramente interpretativo, quando derivada de uma competência vinculada, ou, delinear os contornos dos direitos, assegurados no sistema normativo, quando resultante de uma competência discricionária, a fim de adequá-los aos demais valores albergados no mesmo sistema, impondo aos administrados uma obrigação de não fazer. ${ }^{97}$

Na visão de Maria Sylvia Zanella Di Pietro, o conceito adotado pelo direito brasileiro é o de que:

... o poder de polícia é a atividade do Estado consistente em limitar o exercício dos direitos individuais em benefício do interesse público. ${ }^{98}$

Diogo de Figueiredo Moreira Neto, ao seu estilo, entende que:

...denomina-se polícia a função administrativa que tem por objeto aplicar concreta, direta e imediatamente as limitações e os condicionamentos legais ao exercício de direitos fundamentais, compatibilizando-os com interesses públicos, também legalmente definidos, com a finalidade de possibilitar uma convivência ordeira e valiosa. ${ }^{99}$

96 BANDEIRA DE MELlo, Celso Antônio, Curso de Direito Administrativo, Malheiros, 21 a Ed., São Paulo, 2006, p. 780.

${ }^{97}$ BEZNOS, Clóvis, Poder de Polícia, Revista dos Tribunais, São Paulo, 1979, p. 76.

${ }^{98}$ DI PIETRO, Maria Sylvia Zanella, Direito Administrativo, Atlas, 20a Ed., São Paulo, 2007, p. 104.

${ }^{99}$ MOREIRA NETO, Diogo de Figueiredo, Curso de Direito Administrativo, $15^{\text {a }}$ ed., Ed. Forense, 2009, p. 442 . 
Esta concepção funcional do poder de polícia adéqua-se perfeitamente aos ensinamentos do já mencionado Jorge Miranda, que explica de forma precisa que:

São dois os sentidos possíveis de função do Estado: como tarefa ou incumbência, correspondente a certa necessidade colectiva ou certa zona de vida social; e como actividade com características próprias, modo de o poder político se projectar em ação. ${ }^{100}$

É justamente a imposição destes limites que estabelece os contornos do direito, tornando-o compatível com o exercício do direito das demais pessoas e com os fins sociais que o Estado deve buscar, ou seja, o interesse público. ${ }^{101}$

O poder de polícia para Odete Medauar é substancialmente:

...a atividade da Administração que impõe limites ao exercício de direitos e liberdades. ${ }^{102}$

Para Diógenes Gasparini o poder de polícia traduz-se em uma atribuição de que:

...dispõe a Administração Pública para condicionar o uso, o gozo e a disposição da propriedade e o exercício da liberdade dos administrados no interesse público ou social. ${ }^{103}$

$\mathrm{Na}$ doutrina estrangeira também podemos encontrar a mesma noção. Para Bartolome A. Fiorini:

A função policial se manifesta como a política de equilíbrio necessário, cada vez que a relação entre individuo e bem comum apresenta algum

\footnotetext{
${ }^{100}$ MIRANDA, Jorge, Funções, Órgãos e Atos do Estado, Universidade de Lisboa, 1990, p. 03.

${ }^{101}$ FIGUEIREDO, Lúcia Valle, Curso de Direito Administrativo, 9a edição, Malheiros, São Paulo, 2008, p. 286.

${ }^{102}$ MEDUAR, Odete, Direito Administrativo Moderno, $3^{\text {a }}$ ed., São Paulo, 1999, p. 364.

${ }^{103}$ GASPARINI, Diógenes, Direito Administrativo, 7ª ed., Saraiva, São Paulo, 2002, p.p. 118/119.
} 
desequilíbrio que ponha em crise ou perigo a segurança da ordem imposta. $^{104}$

Otto Mayer, também adepto a um conceito amplo, entendia que:

"La polícia es la actividad del Estado que tiene por fin la defensa del buen orden de la cosa publica, mediante los recursos del poder de la autoridad, contra las perturbaciones que las exitencias individuales pueden ocasionar." 105

Nota-se nestes conceitos que o poder de polícia expressa uma função do Estado, independentemente dos meios que a expressa, que variam para que ela seja empregada da forma mais eficaz possível.

A importância desta classificação do poder de polícia como função é trazer a lume quais os seus dados permanentes, ou seja, qual sua natureza ontológica. A polícia administrativa, na visão clássica, tem sempre a mesma finalidade, muito embora formas variadas de execução. É justamente finalidade permanente que indica o objeto de uma função e a individualiza. ${ }^{106}$

Neste prima, para Ramón Vasquez o poder de polícia é:

...a ação do Estado tendente a limitar coercitivamente, dentro de uma sociedade organizada juridicamente, a atividade individual - que se fosse abrangente poderia atentar contra os interesses e a vida dos membros da coletividade e dos indivíduos mesmo. ${ }^{107}$

Nota-se que na mesma linha de Fiorini, Vasquez entende que o poder de polícia representa simultaneamente uma função e um poder. Este poder se apresenta em forma de normas que visam assegurar e promover o bem-estar social, mas também a propriedade e a felicidade geral, por meio das restrições necessárias através de atos materiais.

Com efeito, fortemente influenciada pela doutrina liberal, a doutrina clássica apresenta o poder de polícia como uma atividade tipicamente

\footnotetext{
${ }^{104}$ FIORINI, Bartolome, Poder de Polícia, Editora Alfa, Buenos Aires, 1962, p. 21.

${ }^{105}$ MAYER, Otto, Derecho Administrativo Alemán, Ed. Depalma, Buenos Aires, 1950, p. 08.

${ }^{106}$ FIORINI, Bartolome, Poder de Polícia, Editora Alfa, Buenos Aires, 1962, pp. 13/14.

${ }^{107}$ VASQUEZ, Ramon, Poder de Polícia, $2^{\mathrm{a}}$ ed., Buenos Aires, 1957, p. 28
} 
administrativa, adstrita a previsão legal que a subordina e, portanto, sujeita ao controle jurisdicional, que não implica a assunção pelo Estado da atividade sob a incidência deste poder. Ele impõe ainda uma dicotomia entre o direito abstrato e o exercício concreto deste direito, uma vez que o limita, sendo exercido com autoridade, mediante a qual lhe é lícito impor sanções no caso de descumprimento de suas ordens. ${ }^{108}$

Não é demais destacar a diferenciação que Cretella Jr. estabelece entre a noção de polícia e o de poder de polícia. Para o mestre, a expressão "polícia" tem um sentido mais restrito, uma vez que o poder de polícia remete a ideia de manifestação do Poder Público que obriga ao administrado, lastreado na supremacia geral que exerce nos termos da lei, conforme verificaremos. ${ }^{109}$

Não pode faltar aqui ainda, o conceito de poder de polícia trazido pela Lei 5.172, de 25 de outubro de 1.966, denominado Código Tributário Nacional pelo Ato Complementar n⿳36/77 que assim dispõe em seu artigo 78:

Art. 78. Considera-se poder de polícia atividade da administração pública que, limitando ou disciplinando direito, interesse ou liberdade, regula a prática de ato ou a abstenção de fato, em razão de interesse público concernente à segurança, à higiene, à ordem, aos costumes, à disciplina da produção e do mercado, ao exercício de atividades econômicas dependentes de concessão ou autorização do Poder Público, à tranquilidade pública ou ao respeito à propriedade e aos direitos individuais ou coletivos. ${ }^{110}$

Nota-se que a abordagem legal é fortemente marcada pelos traços clássicos do instituto, transparecendo a ideia de uma atividade negativa, de limitação do exercício de direitos, com vista à proteção à segurança, salubridade e à tranquilidade pública. Por tratar-se de um código tributário, por óbvio, também prevê o disciplinamento das atividades econômicas, o que não deixa de ser um avanço em relação à ideia liberal clássica.

De todo modo, o conceito clássico do poder de polícia representa um grande avanço em relação à ideia arbitrária de polícia que invariavelmente vigeu até o

\footnotetext{
${ }^{108}$ MEDUAR, Odete, Direito Administrativo Moderno, $3^{\text {a }}$ ed., São Paulo, 1999, p. 367.

${ }^{109}$ CRETELLA JR., José, Direito Administrativo Brasileiro, Editora Forense, $2^{\text {a }}$ edição, Rio de Janeiro 2.000, p. 547.

${ }^{110}$ Redação atribuída pelo Ato Complementar $n^{\circ} 31$, de 28.12.1966.
} 
Estado de Polícia (e em alguns casos até a bem pouco tempo), graças, especialmente a sua forte submissão ao princípio da legalidade e a imposição constitucional de respeito aos direitos e garantias individuais.

Conforme verificaremos, a concepção clássica do poder de polícia não foi superada, mas sim, passou por um processo de forte evolução e aprimoramento, imposto, especialmente, pelas mudanças sociais experimentadas nestes novos tempos. Assim, quando apontamos as principais características do modelo clássico do poder de polícia, o fazemos justamente para enfatizar esta evolução e não tentando fazer crer que foram tornadas inúteis tais peculiaridades.

Uma das principais notas do poder de polícia na concepção clássica - o seu caráter eminentemente negativo - por exemplo, evoluiu, de forma a tornar o poder de polícia ambivalente, no sentido de continuar a impor condutas negativas mas passando a exigir também ações positivas por parte dos cidadãos e das empresas.

Antes, porém, de apresentarmos o poder de polícia em seu estado atual, mister verificarmos as principais características que foram trabalhadas pela doutrina clássica.

\section{II.2 - Características e Atributos}

São muitas as características e atributos que têm marcado de forma indelével a atuação do Estado por meio do poder de polícia. Entre elas, tentaremos apontar as que são, de forma geral, as mais trabalhadas pela doutrina especializada.

De início, vamos tomar de empréstimo a lição da professora Maria Sylvia Zanella Di Pietro ${ }^{111}$ que aponta para três "elementos caracterizadores" principais deste instituto: "o subjetivo (o Estado); o finalístico (interesse público) e o conteúdo (restrição à liberdade individual)".

É seguramente a soma destes elementos que tornam peculiar a atuação do Poder Público no exercício do poder de polícia, distinguindo-o dos demais atos administrativos. Na visão clássica, somente quando o Estado age impondo limites à

${ }^{111}$ DI PIETRO, Maria Sylvia Zanella, Poder de Polícia em Matéria Urbanística, in Temas de Direito Administrativo, Publicação conjunta, Ministério Público de São Paulo/Imprensa Oficial, São Paulo, 1999, p. 24. 
liberdade individual e buscando a realização do interesse público é que estamos diante do poder de polícia.

Antes, porém, da apresentação de qualquer outra característica vale um destaque especial para o fato de que o exercício do poder de polícia encontra seu limite no princípio da legalidade, especialmente quando estão em jogo direitos fundamentais. Neste caso, a previsão de direitos fundamentais indica a restrição ao exercício do poder de polícia, interpretando-se sempre favoravelmente ao exercício do direito.

Este é o raciocínio que deve nortear o intérprete e o agente Público. Se o direito fundamental estiver regulado em lei, esta (lei) deve ser interpretada sempre de modo mais favorável ao exercício do direito. Não havendo norma regulamentadora, o Poder Público deverá atentar para que a medida de polícia seja praticada por agente competente, seja absolutamente necessária, eficaz e proporcional, sob pena de ser considerada ilegal. ${ }^{112}$ Afinal, como afirma Juarez de Oliveira ${ }^{113}$, o poder de polícia não pode ser entendido senão como um mecanismo para evitar: "tornar assimétrico o desfrute simultâneo dos direitos individuais e coletivos."

\section{II.2.1- Supremacia Geral}

A noção de supremacia geral é imprescindível ao correto entendimento da função de poder de polícia. Isto porque, decorre desta característica a resposta correta a questões como a da possibilidade ou não de delegação da função ou de indenização aos particulares decorrentes de seu exercício.

A supremacia geral surge como o atributo através do qual a Administração está autorizada a adotar as medidas conformadoras em relação à propriedade ou ao exercício da liberdade dos indivíduos, com vistas ao estabelecimento do bem-estar geral. A contrapartida deste atributo reside no dever que tem o indivíduo de ajustar-se aos comandos legalmente expedidos no exercício deste poder estatal. ${ }^{114}$

\footnotetext{
${ }^{112}$ MEDUAR, Odete, Direito Administrativo Moderno, $3^{\text {a }}$ ed., São Paulo, 1999, p. 373.

113 FREITAS, Juarez, Poder de Polícia Administrativa - Novas reflexões, BDA/Boletim de Direito Administrativo 6/657-668, Ed. Nova Dimensão, São Paulo, Junho de 2006, p. 658.

${ }^{114}$ PESTANA, Márcio, Direito Administrativo Brasileiro, Campus Jurídico, Rio de Janeiro, 2008, p. 506.
} 
É a supremacia geral o fundamento jurídico do poder de polícia. ${ }^{115}$ Através dela o Estado impõe-se ao administrado como guardião dos interesses públicos estabelecidos pelo sistema ${ }^{116}$.

Otto Mayer ${ }^{117}$, chega a afirmar que é a existência deste dever geral de submissão “...que sólo la polícía tiene que realizar y hacer valer” é que o distingue de todas as demais atividades da Administração.

Tratando esta característica por "vínculo geral", Diógenes Gasparini ${ }^{118}$ explica que é através dele que o Poder Público se vê autorizado a condicionar o uso, o gozo e a disposição dos bens e da liberdade dos cidadãos na busca do interesse público.

De fato, é traço determinante do poder de policia o seu exercício em nome da supremacia geral, que advém da própria supremacia da lei. Por isto, o exercício do poder de polícia não se confunde com outras espécies de imposições realizadas pela Administração, relacionadas com outras espécies de vínculos jurídicos entre o Poder Público e o particular, tais como o relacionamento com usuários de serviços públicos, com os servidores públicos ou em razão de vínculos contratuais. ${ }^{119}$

É no exercício deste poder, desta supremacia, que o Estado atua ora através de medidas concretas, ora através de medidas legislativas ou normativas com vistas a regular e garantir os direitos e interesses públicos. ${ }^{120}$

Ela (supremacia geral) se contrapõe ao que a doutrina internacional, especialmente a alemã, italiana e espanhola denominam de supremacia especial. Nesta os poderes especiais que detém seus agentes não provêm diretamente da lei, mas sim, da própria relação especial que mantém com o administrado.

A supremacia especial surge da necessidade de se estabelecer uma situação jurídica diferenciada para os que mantêm com a Administração, vínculos determinados, o que os coloca em situação especial em relação aos demais indivíduos. Em casos como o do relacionamento com os servidores públicos, dos alunos de determinada

\footnotetext{
${ }^{115}$ BEZNOS, Clóvis, Poder de Polícia, Revista dos Tribunais, São Paulo, 1979, pp. 75.

116 No mesmo sentido: GROTTI, Dinorá Adelaide Musetti, Poder de Polícia - Palestra proferida no Seminário Nacional de Direito Administrativo - Edição Comemorativa dos 20 anos da NDI, BDS/Boletim de Direito Administrativo, 7/753-758, Ed. Nova Dimensão Jurídica, Junho 2006, p. 758.

${ }^{117}$ MAYER, Otto, Derecho Administrativo Alemán, Ed. Depalma, Buenos Aires, 1950, p. 11.

${ }^{118}$ GASPARINI, Diógenes, Direito Administrativo, 7ª ed., Saraiva, São Paulo, 2002, p. 119.

119 BANDEIRA DE MELLO, Celso Antônio, Curso de Direito Administrativo, Malheiros, 21 a Ed., São Paulo, 2006, p. 781.

${ }^{120}$ ARAÚJO, Edmir Netto de, Curso de Direito Administrativo, Saraiva, 5ª Ed., São Paulo, 2010, p. 1048.
} 
instituição pública de ensino ${ }^{121}$, o Estado se vê obrigado a estabelecer regras especiais para $\mathrm{o}$ adequado funcionamento destas atividades e o faz em nome do que se convencionou chamar de supremacia especial. ${ }^{122}$

A supremacia especial, portanto, se origina do relacionamento da Administração com o particular em âmbitos específicos tais como: contratos, estatutos funcionais, etc. ${ }^{123}$.

De todo modo, o fundamental é que não se confundam os fundamentos do exercício das espécies de supremacia, pois, o exercício da supremacia especial nada tem haver com o poder de polícia. ${ }^{124}$

Cumpre esclarecer que mesmo os doutrinadores mais modernos não destoam quanto a esta característica do poder de polícia.

Para Luis Manuel Fonseca Pires ${ }^{125}$, por exemplo, a supremacia geral expressa a natural sujeição dos administrados frente à Administração, com fundamento no pacto social. A supremacia geral é a expressão do Poder que organiza a sociedade em um determinado território sendo, por natureza, difusa, envolvendo toda a sociedade pelo simples fato de estarem sob a égide de determinada organização jurídicoestatal.

Isto ocorre justamente porque seria impossível ao Estado legislar sobre cada uma das situações que a atividade estatal desenvolve em relacionamento específico com particulares.

Carlos Ari Sundfeld, que usa a expressão "relacionamento genérico" no lugar de supremacia geral, explica que é muito mais contundente a submissão ao princípio da legalidade no caso do vinculo genérico com o administrado, pois neste

\footnotetext{
${ }^{121}$ Enquadram-se nesta categoria, por exemplo, os casos dos sentenciados ou dos que estão prestando o serviço militar obrigatório. Nestes casos, por óbvio, não há que se falar em liberdade no relacionamento. A supremacia especial, muito embora também diga respeito ao relacionamento entre o Estado e o administrado, não está relacionada com o "poder de império" mas, ao contrário, advém de um vínculo específico entre as partes. Não se olvide, porém, que esta supremacia especial encontra seu supedâneo justamente na supremacia geral, refletida numa situação determinada e individualizada. Neste sentido: PIRES, Luis Manuel Fonseca, Limitações Administrativas à Liberdade e à Propriedade, Quartier Latin, São Paulo, 2006, pp. 162/163.

122 BANDEIRA DE MELlo, Celso Antônio, Curso de Direito Administrativo, Malheiros, 21 a Ed., São Paulo, 2006, pp. 782/784.

${ }^{123}$ BEZNOS, Clóvis, Poder de Polícia, Revista dos Tribunais, São Paulo, 1979, p. 76.

${ }^{124}$ BANDEIRA DE MELLO, Celso Antônio, Curso de Direito Administrativo, Malheiros, $21^{\text {a }}$ Ed., São Paulo, 2006, p. 787.

${ }^{125}$ PIRES, Luis Manuel Fonseca, Limitações Administrativas à Liberdade e à Propriedade, Quartier Latin, São Paulo, 2006, pp. 162/166.
} 
caso, a atuação da administração encontra tanto o amparo como o limite diretamente na lei, que estabelece o exercício da "atividade ordenadora". 126

Fato é que o próprio fundamento jurídico do poder de polícia encontra-se justamente na supremacia geral. Daí o entendimento de que não que se há que falar em poder de polícia quando o relacionamento entre a Administração e o administrado fundar-se na supremacia especial. ${ }^{127}$

\section{II.2.2 - Competência}

O estabelecimento da competência é outra característica que foi muito bem trabalhada pela doutrina clássica, não sofrendo grande variação na doutrina mais recente.

A competência para exercer as limitações administrativas advém precipuamente da Constituição. Dentro dos parâmetros estabelecidos por ela é que as leis conferem aos agentes públicos a atribuição para desempenhar as funções inerentes ao poder de polícia. ${ }^{128}$

Em alguns casos, porém, a fixação da competência territorial leva em conta o interesse que está em questão. Isto é, verifica-se se a competência é da União, regional ou local, analisando-se o interesse de cada ente da federação na resolução da situação. $^{129}$

Neste contexto, é da competência da União fixar os parâmetros gerais da matéria, restando reservado aos municípios, por exemplo, a competência no que diz respeito ao interesse local.

A legislação sobre direito comercial ou de trânsito, por exemplo, são afetos à União. Nem por isto resta vedado aos municípios exercerem seus poderes de polícia em prol do interesse local, estabelecendo o horário de funcionamento do comércio e os locais de funcionamento dos estabelecimentos em função do zoneamento urbano ou,

\footnotetext{
${ }^{126}$ SUNDFELD, Carlos Ari, Direito Administrativo Ordenador, Malheiros Editores, São Paulo, 2003, p. 25.

${ }^{127}$ PIRES, Luis Manuel Fonseca, Limitações Administrativas à Liberdade e à Propriedade, Quartier Latin, São Paulo, 2006, p 176.

${ }^{128}$ DI PIETRO, Maria Sylvia Zanella, Poder de Polícia em Matéria Urbanística, in Temas de Direito Administrativo, Publicação conjunta, Ministério Público de São Paulo/Imprensa Oficial, São Paulo, 1999, p. 28.

${ }^{129}$ JUSTEN FILHO, Marçal, Curso de Direito Administrativo, $3^{\mathrm{a}}$ edição, Saraiva, São Paulo, 2008, p. 472.
} 
ainda, regulamentar e fiscalizar o trânsito, impondo sanções aos infratores das normas estabelecidas no interesse local. ${ }^{130}$

Márcio Pestana ${ }^{131}$ denomina de "Competências Coniventes" quando órgãos de entes federativos diferentes exercem suas competências exclusivas, de forma concomitante sobre o mesmo particular, como no exemplo do exercício do comércio citado acima.

Há outros casos ainda, em que o exercício do poder de polícia pode suscitar uma atuação conjunta de diversos entes, como nas situações de proteção ao meio ambiente, ou telefonia celular, por exemplo. Nestas hipóteses também se verifica a competência comum entre as esferas de governo. ${ }^{132}$

Outra hipótese que merece ser anotada ocorre quando o ente originalmente competente não possuir meios hábeis de fiscalização. Diante do interesse público manifesto, um ente que não possui competência legislativa, pode exercer as funções de polícia, desde que haja justificado interesse local ou necessidade iminente de recompor a ordem pública. ${ }^{133}$

\section{II.2.3 - Atividade predominantemente negativa}

Esta é uma das características que marcam a noção clássica do poder de polícia. Durante muito tempo sustentou-se a ideia de que o poder de polícia era uma atividade predominantemente negativa, no sentido de quase invariavelmente impor um "não fazer" ao administrado.

A caracterização do poder de polícia como sendo uma atividade negativa é realizada pela maioria dos autores clássicos, que a contrapõe com a atividade de prestação de serviços em que é oferecido pelo Poder Público algum benefício ao particular. Como no exercício do poder de polícia nada é oferecido em termos de vantagens diretas, diz-se, negativa.

\footnotetext{
${ }^{130}$ BANDEIRA DE MELLO, Celso Antônio, Curso de Direito Administrativo, Malheiros, $21^{\text {a }}$ Ed., São Paulo, 2006, p. 803.

${ }^{131}$ PESTANA, Márcio, Direito Administrativo Brasileiro, Campus Jurídico, Rio de Janeiro, 2008, p. 499. 132 JUSTEN FILHO, Marçal, Curso de Direito Administrativo, 3ª edição, Saraiva, São Paulo, 2008, p. 472.

${ }^{133}$ PIRES, Luis Manuel Fonseca, Limitações Administrativas à Liberdade e à Propriedade, Quartier Latin, São Paulo, 2006, pp. 222/223.
} 
Apesar de muitas vezes o Poder Público, através do poder de polícia, impor obrigações de fazer ou de dar, o entendimento prevalente era o de que o poder de polícia implicaria em uma imposição negativa, um não fazer. ${ }^{134}$

Tal entendimento, porém, vem sendo gradativamente modificado pela doutrina que, constatando o exponencial avanço do campo de atuação do poder de policia, fala agora de um forte viés positivo desta função.

Fato é que não se sustenta mais a ideia de que o poder de polícia tenha natureza de poder negativo, no sentido de que se restringe a impor limitações, visando tão somente evitar comportamentos danosos a sociedade.

Tal afirmação, na verdade submete-se ao ângulo pelo qual se analisa a questão. A limitação ao direito de construir, por exemplo, também cria um ambiente urbano mais equilibrado e salutar e neste sentido seria positiva esta atividade de polícia. Assim, muito embora predominantemente negativas, no sentido de impor proibições e limitações (non facere), há atividades de polícia que impõem ao particular condutas comissivas, tais como a exigência de dar ao imóvel uma destinação conforme o Plano Diretor da Cidade. ${ }^{135}$

Com efeito, por força do que prescreve a Constituição Federal em seu artigo 182, o exercício da atividade de polícia pode ser tomada em sentido positivo, atuando como instrumento protagonista de políticas públicas, impondo e cobrando do indivíduo e das empresas condutas positivas (facere) para que a propriedade, (por exemplo) cumpra a sua função social. ${ }^{136}$

Em suma, a velha noção de que o poder de polícia limita-se a impor condutas negativas aos indivíduos, transparecendo um caráter eminentemente repressivo, evoluiu para abarcar também a promoção de atitudes comissivas tendentes a produção do bem estar ${ }^{137}$, num claro exemplo de mudança de paradigmas sobre o tema.

\footnotetext{
${ }^{134}$ BEZNOS, Clóvis, Poder de Polícia, Revista dos Tribunais, São Paulo, 1979, p. 18/24.

135 BANDEIRA DE MELLO, Celso Antonio, Curso de Direito Administrativo, Malheiros, $21^{\text {a }}$ Ed., São Paulo, 2006, pp. 787/790.

${ }^{136}$ FERREIRA, Daniel, Poder de Polícia, in Curso de Direito Administrativo, Marcelo Harger (org.) Ed. Forense, Rio de Janeiro, 2007, p. 367.

${ }^{137}$ JUSTEN FILHO, Marçal, Curso de Direito Administrativo, $3^{\text {a }}$ edição, Saraiva, São Paulo, 2008, p 459.
} 


\section{II.2.4 - Atividade Preventiva/Repressiva}

É do direito francês que herdamos a prática de denominar determinadas atividades de polícia como preventivas ou repressivas. ${ }^{138}$

Themístocles Brandão Cavalcanti ${ }^{139}$, por exemplo, se utilizava desta diferenciação clássica ao tratar do poder de polícia, referindo-se a "medidas repressivas" quando, em estrita obediência à lei, são aplicadas penalidades e a "medidas preventivas" quando, mesmo havendo restrição a alguma liberdade, tal restrição visava evitar um dano maior a coletividade

Ruy Cirne Lima ${ }^{140}$, porém, já há muito advertia que tal critério de classificação não subsistiria a uma análise da "doutrina bem orientada".

$\mathrm{Na}$ verdade o poder de polícia pode adotar características predominantemente preventivas ou repressivas, tendo o termo polícia, do ponto de vista etimológico tomado um sentido de vigiar, reprimir, conter.

Muito embora no direito brasileiro existam órgãos que exerçam tanto a atividade preventiva quanto a atividade repressiva, não há que se falar propriamente em um poder de polícia misto, pois na verdade estamos nos referindo à estruturação dos órgãos que exercem a atividade policial e não propriamente a natureza do poder de polícia exercido.

Mesmo a noção de que a polícia administrativa é preventiva e a polícia judiciária é repressiva não pode ser tomada de forma absoluta. Na verdade o que ocorre é que as atividades de polícia podem ser tomadas sob o aspecto de sua predominância, ora repressiva, ora preventiva, mas isto não lhes atribui um aspecto diferenciador definitivo e estanque. ${ }^{141}$

A verdade é que tal distinção não prima pela técnica. Isto porque, há inúmeras situações em que a atuação da polícia administrativa destina-se a repressão da atividade nociva a sociedade, como por exemplo, quando constata a venda de alimentos

\footnotetext{
${ }^{138}$ MAYER, Otto, Derecho Administrativo Alemán, Ed. Depalma, Buenos Aires, 1950, p. 16.

139 CAVAlCANTI, Themístocles Brandão, Princípios Gerais de Direito Administrativo, Editora Freitas Bastos, São Paulo, 1945, p. 425.

${ }^{140}$ CIRNE LIMA, Ruy, Princípios de Direito Administrativo, Malheiros Editores, 5a Ed., São Paulo, 1982, p. 113.

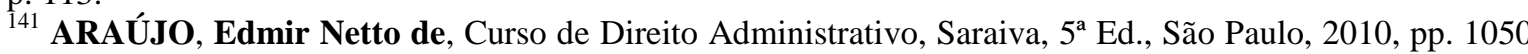
e 1051 .
} 
deteriorados e os apreende; quando flagra uma infração de trânsito e aplica a multa cabível; quando fecha um estabelecimento que comercializa produtos ilegais, etc. ${ }^{142}$

De fato, esta distinção, apesar de largamente difundida, não faz sentido. Na verdade a repressão ou a prevenção são momentos distintos da mesma atividade, não possuindo nenhum caráter científico de conteúdo substancial esta classificação. Pode-se dizer inclusive, que a atividade preventiva coincida com a repressiva, pois apenas o fator temporal do processo os separa. ${ }^{143}$

Certo é que a distinção que se faz entre a polícia administrativa e a polícia judiciária, levando em conta tão somente o caráter preventivo ou repressivo de uma ou de outra, certamente não prima pela precisão técnica. Isto porque, na realidade, podemos observar no exercício do mesmo ato de polícia uma atuação ora predominantemente repressiva, ora preventiva. Quando a polícia administrativa apreende uma arma de fogo ou um veículo sem condições de trafegar, por exemplo, certamente está agindo a um só tempo de forma repressiva, sujeitando o infrator a ver recolhido o bem, mas também de forma preventiva, no sentido de preservar a sociedade de eventual dano que o possuidor da arma ou o proprietário do veículo sem condições de uso poderiam causar. $^{144}$

Do mesmo modo, a polícia judiciária ao apreender uma carga clandestina, ou mesmo prender um meliante, também atua de forma preventiva no sentido de estar protegendo a sociedade do mal que estes poderiam causar futuramente.

Conforme já observava Otto Mayer ${ }^{145}$, a classificação do poder de polícia nestes termos, na verdade soa "bastante ingênua".

$\mathrm{O}$ que distingue de modo seguro a atividade da polícia administrativa da polícia judiciária é o fato de que esta atua com vista a tornar efetiva a aplicação da legislação penal e processual penal enquanto a polícia administrativa ocupa-se com a aplicação das normas de caráter administrativo, não tendo o condão de responsabilizar os violadores criminalmente. ${ }^{146}$

Com efeito, a melhor classificação é aquela que leva em conta o ramo de direito que rege cada uma das polícias ora tratadas, de modo que será considerada

\footnotetext{
${ }^{142}$ BANDEIRA DE MELLO, Celso Antônio, Curso de Direito Administrativo, Malheiros, $21^{\text {a }}$ ed., São Paulo, 2006, p. 791.

${ }^{143}$ FIORINI, Bartolome, Poder de Polícia, Editora Alfa, Buenos Aires, 1962., p. 181.

${ }^{144}$ DI PIETRO, Maria Sylvia Zanella, Direito Administrativo, Atlas, 20ª Ed., São Paulo, 2007, p. 105.

${ }^{145}$ MAYER, Otto, Derecho Administrativo Alemán, Ed. Depalma, Buenos Aires, 1950, p. 16.

146 BANDEIRA DE MELLO, Celso Antônio, Curso de Direito Administrativo, Malheiros, 21 a Ed., São Paulo, 2006, pp. 791/792.
} 
polícia administrativa aquela que atua com base no Direito Administrativo, tendo sua incidência sobre os bens, direitos e atividades dos particulares; enquanto que a polícia judiciária é aquela que atua conforme as prescrições da lei penal e processual penal, recaindo seus poderes sobre as pessoas. ${ }^{147}$

Seria, portanto mais técnico afirmar, acompanhando Márcio Pestana ${ }^{148}$, que o exercício do poder de polícia administrativa é completamente exaurido no âmbito da Administração, enquanto a polícia judiciária tem natureza instrumental ao futuro processo judicial que será eventualmente instaurado com base nos elementos levantados durante a atuação policial.

Portanto, ao se estabelecer as diferenciações entre as espécies de polícia, especialmente a judiciária e a administrativa, o intérprete deve ter em conta o ponto de vista de suas características predominantes, ou seja, o fato de que a polícia administrativa, com base na legislação e normas administrativas, regula as atividades; enquanto a polícia judiciária, regida por normas penais, incide sobre as pessoas. ${ }^{149}$

\section{II.2.5 - Atividade discricionária/vinculada.}

Conforme é sabido, todo ato administrativo se desenvolve nos limites preestabelecidos pela lei, que se traduz num vínculo insuperável que subordina não só a autoridade, mas também a própria liberdade de ação desta. Porém, para tornar possível o desempenho das atividades de seus agentes, o Estado não pode prescindir de uma certa margem de liberdade de atuação - a chamada discricionariedade administrativa.

Nas palavras de Caio Tácito:

Chama-se a esse limite ou contenção legal do poder administrativo de poder vinculado, porque todo ato administrativo está subordinado ou ligado a uma norma jurídica anterior, ou seja, à regra de competência que permite ao agente a prática do ato administrativo.

\footnotetext{
${ }^{147}$ DI PIETRO, Maria Sylvia Zanella, Direito Administrativo, Atlas, 20ª Ed., São Paulo, 2007, p. 105.

${ }^{148}$ PESTANA, Márcio, Direito Administrativo Brasileiro, Campus Jurídico, Rio de Janeiro, 2008, p. 505.

${ }^{149}$ ARAÚJO, Edmir Netto de, Curso de Direito Administrativo, Saraiva, 5ª Ed., São Paulo, 2010, p. 1051.
} 
Esta subordinação não significa, porém, que à Administração esteja vedada uma certa latitude de apreciação dos fatos e soluções, independentemente de uma predeterminação legal. ${ }^{150}$

A discricionariedade, portanto, deve ser entendida como uma liberdade atribuída ao agente público para o bom desempenho de uma função, porém, jamais pode ser interpretada como um livre arbítrio. Para Santi Romano:

"No mai il pieno arbítrio, ma il "prudente arbítrio"151

Este raciocínio, que norteia de forma geral os atos da Administração, é especialmente caro ao exercício do poder de polícia tendo em vista as suas peculiaridades.

Especificamente sobre o poder de policia Álvaro Lazzarini declara que: "a discricionariedade é o uso da liberdade legal de valoração das atividades policiadas. ", 152

Temos, pois, que exercício do poder de polícia, via de regra, é discricionário para o Estado, no sentido de que, dentro do que determina a norma, caberá a Administração a escolha da conveniência e da oportunidade de agir. Sem embargos, porém, em função da natureza do interesse público envolvido, tal atividade pode vir a se tornar vinculada, ou seja, um impositivo legal. ${ }^{153} /{ }^{154}$

Certo é que não há que se falar em poder absolutamente discricionário em termos de Administração Pública de modo geral e não é diferente o caso da polícia administrativa. ${ }^{155} \mathrm{O}$ que se observa em alguns casos é a utilização da

\footnotetext{
${ }^{150}$ TÁCITO, Caio, Temas de Direito Público (Estudos e Pareceres), Renovar, Rio de Janeiro, 1997, p. 315.

${ }^{151}$ ROMANO, Santi, Principi di Diritto Constitucionale Generale, Ed. Giufrè, Milano, 1947, p. 111.

152 LAZZARINI, Álvaro, Temas de Direito Administrativo, $2^{\mathrm{a}}$ ed., Editora Revista dos Tribunais, São Paulo, 2003, p. 266.

${ }^{153}$ ARAÚJO, Edmir Netto de, Curso de Direito Administrativo, Saraiva, 5ª Ed., São Paulo, 2010, pp. 1050 e 1048.

${ }^{154}$ No mesmo sentido: DI PIETRO, Maria Sylvia Zanella, Poder de Polícia em Matéria Urbanística, in Temas de Direito Administrativo, Publicação conjunta, Ministério Público de São Paulo/Imprensa Oficial, São Paulo, 1999, p. 26.

${ }^{155}$ BANDEIRA DE MELlO, Celso Antônio, Curso de Direito Administrativo, Malheiros, $21^{a}$ Ed., São Paulo, 2006, pp. 794/795.
} 
competência discricionária, isto é, uma certa margem de escolha dentro dos poderesdeveres estabelecidos por lei. ${ }^{156}$

Deste modo, como muito bem observa Lazzarini ${ }^{157}$, a discricionariedade do poder de polícia jamais pode ser tomada como arbítrio, sob pena de descaracterização desta função.

Juarez de Oliveira assevera ainda que:

Aliás, a discricionariedade, em acepção absoluta, é incompatível com a idéia de poder legitimamente exercido. ${ }^{158}$

Nas palavras de Hely Lopes Meirelles ${ }^{159}$, o poder de polícia é apenas "em princípio discricionário", uma vez que pode tornar-se vinculado na medida em lei assim o determinar especificando de forma minudente o modo de seu exercício.

No mesmo quadrante se posiciona Márcio Pestana ${ }^{160}$ para quem a discricionariedade se manifesta em casos em que, dentro do que prevê a lei, o agente público precisa avaliar concretamente a melhor forma de aplicar a norma. A este espaço de avaliação o professor Antônio Carlos Cintra do Amaral ${ }^{161}$ atribui o nome de "moldura legal”, termo, aliás, tomado de empréstimo de Kelsen.

A atividade administrativa de polícia pode ser prevista em lei em caráter vinculado ou discricionário. O que não é correto afirmar é que o poder de polícia tem natureza discricionária.

Ora, o que se observa em alguns casos é que a lei concede um maior grau de liberdade de atuação, porém, tal liberdade é atribuída e limitada pela própria lei. Sem prejuízo, há atos de polícia administrativa que são totalmente vinculados, o que afasta totalmente a ideia de que o poder de polícia é um "poder discricionário". ${ }^{162}$

\footnotetext{
${ }^{156}$ No mesmo sentido: GRAU, Eros Roberto, Poder de Polícia: Função Administrativa e Princípio da Legalidade: O Chamado "Direito Alternativo", Revista Trimestral de Direito Público, no 01/1993, Editora Malheiros, p. 95.

157 LAZZARINI, Álvaro, Temas de Direito Administrativo, $2^{a}$ ed., Editora Revista dos Tribunais, São Paulo, 2003, p. 267.

${ }^{158}$ FREITAS, Juarez, Poder de Polícia Administrativa - Novas Reflexões, BDA/Boletim de Direito Administrativo 6/657-668, Ed. Nova Dimensão, São Paulo, Junho de 2006, p. 660.

${ }^{159}$ MEIRELLES, Hely Lopes, Direito Municipal Brasileiro, $12^{\mathrm{a}}$ ed., Malheiros Editores, São Paulo, 2001, p. 446.

${ }^{160}$ PESTANA, Márcio, Direito Administrativo Brasileiro, Campus Jurídico, Rio de Janeiro, 2008, p. 494.

161 AMARAL, Antônio Carlos Cintra, Teoria do Ato Administrativo, Editora Fórum, Belo Horizonte, 2008, p. 107.

${ }^{162}$ JUSTEN FILHO, Marçal, Curso de Direito Administrativo, $3^{\mathrm{a}}$ edição, Saraiva, São Paulo, 2008, p. 470.
} 
Vale insistir que, por maior que seja a abrangência do poder de policia, não pode ser exercido pelo Estado de modo totalmente arbitrário. Certa margem de discricionariedade, que é traço característico deste poder, não pode ser tomada como uma faculdade para interferir na atividade individual sem qualquer limite. ${ }^{163}$

Em verdade, não há para a Administração uma liberdade de atuar ou não no exercício deste poder. A atuação é sempre vinculada, ou seja, havendo necessidade de proteger o interesse coletivo, deverá agir o Estado. ${ }^{164}$

Somente quando a lei não limita rigorosamente a forma de intervenção através do poder de polícia é que a Administração atua com certa margem na identificação dos limites dos direitos, a fim de compatibilizá-los com o interesse coletivo. $^{165}$

Subordina-se, pois, à lei a discricionariedade inerente ao poder de polícia e nela deve encontrar o grau e os limites de seu exercício, de forma a tornar mais adequado o tratamento circunstancial dos eventos submetidos à sua incidência. ${ }^{166}$

Segundo Caio Tácito, a liberdade de atuação nos atos de polícia devem se ater a legalidade do fim objetivado na ação. Tal controle de legalidade da discricionariedade, para ele é de fundamental importância, pois:

... corresponde à eliminação dos processos maliciosos e sub-reptícios (e, por isso mesmo, socialmente mais nocivos) de arbítrio administrativo acobertado pelo aparente respeito à lei. ${ }^{167}$

Cumpre ponderar que quando a lei, levando em conta a natureza de determinada atividade e a potencialidade danosa da mesma, já fixa todos os parâmetros para o seu exercício, caberá tão somente à Administração a fiscalização do cumprimento destas balizas legais. No entanto, existem situações que só podem ser avaliadas em concreto. Nestes casos é que caberá a Administração, diante das circunstâncias, avaliar a necessidade e a melhor forma de intervenção. ${ }^{168}$

\footnotetext{
${ }^{163}$ VASQUEZ, Ramon, Poder de Polícia, 2a ed., Buenos Aires, 1957, p. 37.

${ }^{164}$ PIRES, Luis Manuel Fonseca, Limitações Administrativas à Liberdade e à Propriedade, Quartier Latin, São Paulo, 2006, p. 201.

165 BANDEIRA DE MELlo, Celso Antônio, Curso de Direito Administrativo, Malheiros, $21^{a}$ Ed., São Paulo, 2006, p. 777.

166 JUSTEN FILHO, Marçal, Curso de Direito Administrativo, $3^{\text {a }}$ edição, Saraiva, São Paulo, 2008, p. 460.

167 TÁCITO, Caio, Temas de Direito Público (Estudos e Pareceres), Renovar, Rio de Janeiro, 1997, p. 531.

${ }^{168}$ São exemplos, conf. BANDEIRA DE MELLO, Celso Antônio: "quando dissolve passeata, por comportamento violento, destruidor de bens e agressivo à incolumidade física dos transeuntes, quando
} 
De fato, há situações em que a limitação de determinada atividade se impõe de modo preventivo e transitório, até que a Administração possa verificar se o exercício da mesma não causará dano à coletividade e que será exercida na forma estabelecida em lei. Em outros casos, a Administração tem até mesmo a discricionariedade de decidir se o exercício de determinada atividade ou a prática de determinado ato é conveniente à sociedade, sendo absolutamente vedada sua prática sem a prévia autorização.

No primeiro caso, estamos diante de atos totalmente vinculados em que, preenchidos os requisitos legais, tem o particular o direito ao seu exercício, como no caso do direito de edificar. No segundo caso, não há que se falar em direito, pois, o exercício da atividade é considerado vedado, salvo admitido de forma especial pela Administração. É exemplo deste, a autorização para o porte de arma, sem a qual, é considerada conduta ilícita. ${ }^{169}$

Repise-se, isto ocorre porque que a discricionariedade, que permeia o ato de polícia é exercida nos limites da liberdade que a lei confere ao ato. Assim, há casos em que o legislador confere uma margem maior de discricionariedade para o administrador, uma vez que não pode descer às nuances de todos os casos concretos que regula. Porém, há casos em que a lei já estabelece todos os requisitos do ato, não dando margem para qualquer discricionariedade do agente público, tornando-os vinculados. ${ }^{170}$

A licença é a expressão dos atos vinculados, em que preenchidos os requisitos legais, a administração não pode recusar-se a expedi-la.

Já no caso da autorização, a lei confere a Administração a possibilidade de análise da conveniência e da oportunidade da expedição do ato, geralmente em situações em que cada caso deve ser avaliado de per si.

Vale reforçar que é inevitável certo grau de discricionariedade em face da constatação de que a lei não é capaz de prever todas as situações da vida cotidiana e suas peculiaridades, restando ao agente público, diante do caso concreto, aplicar a lei do modo mais conveniente e oportuno.

interrompe espetáculo público, pela prática de atos obscenos de natureza criminosa, ou pela inexistência do perigo que justifique a persistência de uma vedação genérica, por ela mesma absolvível, casuisticamente. É, verbi gratia, o caso da autorização de porte de arma." In: Curso de Direito Administrativo, Malheiros, $21^{\mathrm{a}}$ Ed., São Paulo, 2006, p.778.

169 BANDEIRA DE MELlo, Celso Antônio, Curso de Direito Administrativo, Malheiros, 21 a Ed., São Paulo, 2006, p 791.

${ }^{170}$ DI PIETRO, Maria Sylvia Zanella, Direito Administrativo, Atlas, 20ª Ed., São Paulo, 2007, p. 106. 
Há que ser levado em conta o fato de que o dinamismo da vida moderna gera situações a respeito das quais sequer houve tempo de se legislar. Nestes casos, poderá ser necessária uma atuação administrativa que, muito embora discricionária, deverá observar a lógica do sistema jurídico, os princípios gerais do direito, ou seja, o âmbito das competências jurídicas implícitas. ${ }^{171}$

\section{II.2.6 - Outras Características}

Além das características especialmente apontadas acima, a doutrina clássica tem apontado ainda outros traços característicos do poder de polícia. Procuramos destacar aqui aqueles de maior relevo para o estudo que fazemos.

Comecemos por destacar que o poder de polícia impõe uma dicotomia entre o direito abstrato e o exercício concreto deste direito, uma vez que o limita, sendo exercido com autoridade, mediante a qual lhe é lícito impor sanções no caso de descumprimento de suas ordens ${ }^{172}$.

A irretroatividade é outro traço característico, uma vez que os atos de polícia do Estado não podem atingir o ato jurídico perfeito, o direito adquirido ou a coisa julgada. Nota-se claramente este fenômeno na questão do uso e ocupação do solo em que as mudanças nas regras de ocupação urbana não podem afetar aqueles que construíram regularmente, nos moldes da legislação vigente à época da expedição da licença para construção. ${ }^{173}$

Enterría e Fernández ${ }^{174}$ destacam que os atos de polícia administrativa não dão direito a indenização. Por força de prescrições constitucionais e legais, limitam-se a conformar o exercício dos direitos e liberdades, tornando-os compatíveis com os padrões legais, não havendo que se falar em dano ou prejuízo e, por isto, não sendo indenizáveis. ${ }^{175}$

\footnotetext{
${ }^{171}$ JUSTEN FILHO, Marçal, Curso de Direito Administrativo, $3^{\text {a }}$ edição, Saraiva, São Paulo, 2008, p. 470. ${ }^{172}$ MEDUAR, Odete, Direito Administrativo Moderno, $3^{a}$ ed., São Paulo, 1999, p. 367.

${ }^{173}$ JUSTEN FILHO, Marçal, Curso de Direito Administrativo, $3^{\text {a }}$ edição, Saraiva, São Paulo, 2008, p. 475.

174 ENTERRÍA, Eduardo Garcia de, e FERNANDÉZ, Thomás-Ramón. Curso de Derecho Administrativo, $4^{\text {a }}$ Ed., Vol II, Civitas, Madri, 1997, p. 115.

${ }^{175}$ PESTANA, Márcio, Direito Administrativo Brasileiro, Campus Jurídico, Rio de Janeiro, 2008, p. 492.
} 
Não há que se falar em indenização nestes casos, uma vez que os atos de polícia se limitam a regular a liberdade e a propriedade dos indivíduos, sem que o Estado exerça um domínio eminente sobre estes direitos. ${ }^{176}$

Outro ponto relevante é o de que o exercício do poder de polícia não se confunde com a imposição de sanção. Isto porque, não tem um caráter punitivo. Na verdade as limitações impostas pelo poder de polícia têm natureza finalística diversa da sanção, visando tão somente regular o exercício de um direito e não o de penalizar o indivíduo por algum ilícito cometido. Ademais, ao contrário das sanções, o exercício do poder de polícia pode ter um caráter exclusivamente preventivo, acautelatório ou instigador ao cumprimento da lei. ${ }^{177}$

O exercício efetivo e regular do poder de polícia, por outro lado, por força do que prescreve o artigo 77 do Código Tributário Nacional ${ }^{178}$ pode dar ensejo a cobrança de taxa por parte do Poder Público. ${ }^{179}$

${ }^{176}$ GARCIA VITTA, Heraldo, Poder de Polícia, Malheiros Editores, São Paulo, 2010, p. 67.

${ }^{177}$ OSÓRIO, Fábio Medina, Direito Administrativo Sancionador, $3^{\text {a }}$ ed., Editora Revista dos Tribunais, São Paulo, 2009, pp. 96/97.

${ }_{178}$ Art. 77. "As taxas cobradas pela União, pelos Estados, pelo Distrito Federal ou pelos Municípios, no âmbito de suas respectivas atribuições, têm como fato gerador o exercício regular do poder de polícia, ou a utilização, efetiva ou potencial, de serviço público específico e divisível, prestado ao contribuinte ou posto à sua disposição". (g.n.)

179 Sobre o tema vale a menção ao Agravo 808.006/MS do STJ, de relatoria do Min. HUMBERTO MARTINS:

EMENTA

TRIBUTÁRIO - TAXA DE LOCALIZAÇÃO E FUNCIONAMENTO - PODER DE POLÍCIA LEGITIMIDADE DA REFERIDA TAXA - PRECEDENTES DO STF E STJ - INCIDÊNCIA DO COMANDO DO ARTIGO 557, $\S 1^{\circ}$, DO CPC - AGRAVO DE INSTRUMENTO CONHECIDO PARA DAR PROVIMENTO AO RECURSO ESPECIAL. DECISÃO

Vistos.

Cuida-se de agravo de instrumento interposto pelo Município de Campo Grande em face de decisão que negou trânsito ao recurso especial, com fundamento de que a matéria encontra-se pacificada nesta Corte de Justiça.

No parecer à fl. 64, o Ministério Público Federal afirma que o aresto recorrido, quanto à matéria de fundo, encontra-se em conformidade com a jurisprudência desta corte.

É, no essencial, o relatório.

Esta Corte Superior de Justiça consolidou o entendimento, consubstanciado no verbete sumular 157/STJ, no sentido da ilegalidade da cobrança, pelo Município, de taxa na renovação de licença para localização de estabelecimento comercial ou industrial. Ocorre, contudo, que o Supremo Tribunal Federal se posicionou em sentido diametralmente oposto ao acima esposado, ou seja, concluiu pela constitucionalidade da cobrança da referida taxa, como se pode observar pela leitura da seguinte ementa, verbis:

"TRIBUTÁRIO. MUNICÍPIO DE PORTO ALEGRE. TAXA DE FISCALIZAÇÃO DE LOCALIZAÇÃO E FUNCIONAMENTO. ESCRITÓRIO DE ADVOGADO. CONSTITUCIONALIDADE.

O Supremo Tribunal Federal tem sistematicamente reconhecido a legitimidade da exigência, anualmente renovável, pelas Municipalidades, da taxa em referência, pelo exercício do poder de polícia, não podendo o contribuinte furtar-se à sua incidência sob alegação de que o ente público não exerce a fiscalização devida, não dispondo sequer de órgão incumbido desse mister.

Recurso extraordinário conhecido e provido." (RE 198.904/RS, Rel. Min. Ilmar Galvão, DJ 27.9.1996)

Na linha de raciocínio do Pretório Excelso, a Primeira Seção deste Tribunal, na assentada de 24.4.2002, houve por bem determinar o cancelamento da sobredita Súmula (REsp 261.571/SP, Rel. Min. Eliana Calmon). 
Outro interessante aspecto que é levado em conta pela doutrina clássica é o da aplicação da regra do "favor libertatis" ou "pro libertate”, segundo a qual, todas as medidas administrativas de polícia a serem aplicadas ao caso concreto devem, na dúvida, serem tomadas em favor da liberdade, ou seja, primando para que haja o mínimo de restrição possível. ${ }^{180}$

Em razão do princípio do "favor libertatis", resta vedado a Administração o uso indiscriminado de medidas que afetem a liberdade individual, especialmente quando haja meios menos onerosos para se atingir o interesse público perseguido. $^{181}$

A lógica do Estado de Direito é a de que seja garantido ao indivíduo o exercício de seus direitos com o máximo de liberdade possível. Em outras

Dessarte, na espécie, é legítima a cobrança, pelo Município, da taxa de fiscalização, localização e funcionamento, em razão do exercício do poder de polícia do Município, cumpridas as exigências dos artigos 77 e 78 do Código Tributário Nacional.

Com efeito, conforme ressaltado no Recurso Extraordinário 113.441/SP, da relatoria do insigne Ministro Ilmar Galvão, "é evidente que a fiscalização permanente do cumprimento das exigências legais depende do funcionamento da máquina administrativa e fiscal, acarretando despesas custeadas através da própria taxa. Por outro lado, a cobrança não é apenas relativa à localização, compreendendo também o funcionamento, que exigem um policiamento contínuo, permanente, que não se esgota com a concessão do alvará de funcionamento. Daí ser cabível a renovação anual da taxa".

A título de ilustração, cumpre apontar julgados desta Corte:

"TRIBUTÁRIO. RECURSO ESPECIAL. TAXA DE FUNCIONAMENTO E FISCALIZAÇÃO. LEGALIDADE. CANCELAMENTO DA SÚMULA N. 157/STJ. VIOLAÇÃO DO ART. 333 DO CPC. AUSÊNCIA DE PREQUESTIONAMENTO. SÚMULAS N. 282 E 356 DO STF.

1. O prequestionamento dos dispositivos legais tidos como violados é requisito indispensável à admissibilidade do recurso especial.

2. Afigura-se legítima a cobrança pelo município de taxa de localização, funcionamento e instalação ou fiscalização.

3. Modificação de entendimento do Superior Tribunal de Justiça efetivada com o cancelamento da Súmula n. 157/STJ.

4. Recurso especial parcialmente conhecido e, nessa parte, provido. Acórdão Vistos, relatados e discutidos os autos em que são partes as acima indicadas, acordam os Ministros da Segunda Turma do Superior Tribunal de Justiça, por unanimidade, nos termos do voto do Sr. Ministro Relator, conhecer parcialmente do recurso e, nessa parte, dar-lhe provimento. Os Srs. Ministros Castro Meira, Humberto Martins e Herman Benjamin votaram com o Sr. Ministro Relator.

Ausente, justificadamente, a Sra. Ministra Eliana Calmon Presidiu o julgamento o Sr. Ministro João Otávio de Noronha." (REsp 539100/SP, Rel. Min. João Otávio de Noronha, Data da Publicação/Fonte DJ 9.10.2006)

"PROCESSUAL CIVIL E TRIBUTÁRIO - TAXA DE FISCALIZAÇÃO DE LOCALIZAÇÃO E FUNCIONAMENTO - LEGITIMIDADE DA COBRANÇA - ART. 77 DO CTN.

1. Consoante orientação traçada pelo STF, a cobrança da taxa de localização e funcionamento, pelo Município, prescinde da comprovação da efetividade da atividade fiscalizadora, bastando seu exercício em potencial.

2. Recurso especial improvido."

(REsp 698559/MG, Rel. Min. ELIANA CALMON, Segunda Turma, 20.9.2005,

Data da Publicação10.10.2005, p. 327)

${ }^{180}$ MEDUAR, Odete, Direito Administrativo Moderno, $3^{\text {a }}$ ed., São Paulo, 1999, p. 370.

${ }^{181}$ CASSAGNE, Juan Carlos, Derecho Administrativo, 6ª Ed., Abeledo-Perrot, Buenos Aires, 2000, p. 473. 
palavras, a atuação da polícia administrativa deve se desenvolver do modo que menos cause transtornos às liberdades exposta à sua influência. ${ }^{182}$

Isto remete para outra característica, que os franceses e espanhóis chamam de proporcionalidade, e os norte-americanos chamam de razoabilidade, ou seja, os meios aplicados pela administração devem guardar coerência com o fim a que se destinam. $^{183}$

Lembrando que o princípio da proporcionalidade é uma noção muito antiga, forjada como o estudo do "justo meio" mesotes compilado por Aristóteles, Juarez Freitas ${ }^{184}$ ensina que foi no campo da polícia administrativa que tal elemento foi introduzido no Direito moderno.

O entendimento de que o poder de polícia deve ser exercido de forma razoável ou proporcional é de grande relevância, pois é um dos traços que diferenciam o uso deste importante instrumento no Estado de Direito em relação ao modo como era utilizado nos tempos do "Estado de Polícia", conforme vimos.

Em obediência a tal princípio, a atuação administrativa restringe-se a observância da finalidade estampada na norma, resguardando o particular dos eventuais abusos. $^{185}$

Com vistas a observância da razoabilidade, o Estado deve se resguardar do uso de medidas mais enérgicas, evitando a todo custo que o particular seja constrangido por sua atuação, não sendo lícito que seja utilizado meio que imprima uma restrição que exorbite do que seja extremamente necessário ao atingimento do interesse público. Para tanto, o Estado não pode perder de vista o trinômio: "lei/finalidade/proporcionalidade". 186

Por fim vale citar a oportuna a observação de Ruy Cirne Lima ${ }^{187}$ para quem é característica do poder de polícia: "assegurar o concorrente exercício de todas as atividades e a conservação perfeita de todas as propriedades privadas.”

\footnotetext{
${ }^{182}$ FREITAS, Juarez, Poder de Polícia Administrativa - Novas reflexões, BDA/Boletim de Direito Administrativo 6/657-668, Ed. Nova Dimensão, São Paulo, Junho de 2006, p. 662.

${ }^{183}$ MEDUAR, Odete, Direito Administrativo Moderno, $3^{\text {a }}$ ed., São Paulo, 1999, p. 370.

184 FREITAS, Juarez, Poder de Polícia Administrativa - Novas Reflexões, BDA/Boletim de Direito Administrativo 6/657-668, Ed. Nova Dimensão, São Paulo, Junho de 2006, p. 661.

${ }^{185}$ GARCIA VITTA, Heraldo, Poder de Polícia, Malheiros Editores, São Paulo, 2010, p. 176.

186 FREITAS, Juarez, Poder de Polícia Administrativa - Novas reflexões, BDA/Boletim de Direito Administrativo 6/657-668, Ed. Nova Dimensão, São Paulo, Junho de 2006, p. 661.

${ }^{187}$ CIRNE LIMA, Ruy, Princípios de Direito Administrativo, Malheiros Editores, $5^{\text {a }}$ Ed., São Paulo, 1982, p. 108
} 


\section{III - CRÍTICAS CLÁSSICAS E MODERNAS AO PODER DE POLÍCIA}

Apresentada a evolução histórica do instituto e exposta a visão que a doutrina clássica sedimentou, cumpre-nos, antes de avançarmos rumo ao retrato atual do poder de polícia, analisar as críticas que a matéria vem sofrendo da parte de alguns autores.

Entendemos apropriado reunirmos e examinarmos aqui, tanto as críticas mais tradicionais, como as mais recentes observações da doutrina, na intenção de tornarmos mais lógica a abordagem.

\section{III.1 - Críticas à Noção de Poder de Polícia}

Como temos visto no decorrer deste trabalho, o poder de polícia é, seguramente, um dos mais polêmicos entre os temas de Direito Administrativo. Não é novidade entre os autores que se dedicaram a questão a controvérsia, inclusive quanto a sua existência como atividade independente das demais atividades estatais, a ponto de merecer um estudo em separado.

Autores como Clóvis Beznos ${ }^{188}$ questionam até mesmo se na vigência do Estado de Direito é possível falar-se em atividade de polícia em contraposição às demais atividades do Estado ao ponto de merecer uma classificação própria com respaldo cientifico. Em outras palavras, indaga-se se o poder de polícia apresenta peculiaridades suficientes para ser considerada diferenciada das demais atividades estatais.

Conforme anota a doutrina mais crítica, o poder de polícia consistia em uma das principais funções do Estado absoluto, junto com a militar, a financeira e a justiça. Porém, no Estado moderno, restaram mantidos seus mecanismos e sua linguagem, contradizendo a vigência plena do direito. Segundo esta corrente de pensamento, o instituto está impregnado por uma terminologia antiga, com traços absolutistas, com forte significado político. ${ }^{189}$

\footnotetext{
${ }^{188}$ BEZNOS, Clóvis, Poder de Polícia, Revista dos Tribunais, São Paulo, 1979, p. 46.

${ }^{189}$ FIORINI, Bartolome, Poder de Polícia, Editora Alfa, Buenos Aires, 1962, p. 10.
} 
Para Clóvis Beznos ${ }^{190}$, o poder de polícia apresentava peculiaridades especiais no surgimento do estado liberal na medida em que tinha seu âmbito de atuação voltado para a segurança, a salubridade e a moralidade, possuindo uma característica negativa. No entanto, tais características foram incorporadas pelo processo legislativo, de forma que o que antes era considerado como sendo direito natural, a ser resguardado pelo poder público, passou a ser abrangido pelo direito positivo.

Segundo Gordillo ${ }^{191}$, não se poderia mais sustentar que o Estado só se utilizasse do poder de polícia para proteger a salubridade, a segurança e a moralidade. $\mathrm{Na}$ verdade, todo o bem estar, de modo geral, estaria adstrito aos fins a que o Estado persegue e, portanto, diluído estaria o poder de polícia entre as suas múltiplas funções.

Para os adeptos desta teoria, justamente esta ampliação do alcance do poder de polícia é que fez com que ele perdesse suas características originais, não sendo mais possível falar-se de uma noção própria de poder de polícia. Para eles a função de poder de policia foi pulverizada na Administração, diluindo-se conceitualmente.

Sob influência confessa das lições de Gordillo, Lucia Valle Figueiredo $^{192}$, mais recentemente, sustenta que a alusão ao poder de polícia é extemporânea e que, na verdade, o exercício do que se denomina poder de polícia se confunde com as demais atividades administrativas. Para ela, como as limitações aos direitos e à liberdade só podem ser estabelecidas por lei, não há razão para se referir a um poder da Administração. A função da administração, no caso, seria como nos demais, o de cumprir a lei.

Segundo esta visão, já não mais vige a noção liberal de poder de polícia, na qual o Estado só interviria naquelas situações clássicas (segurança, saúde e moralidade) e, portanto, a promoção do bem comum e o resguardo dos perigos a que são expostos os cidadãos, são noções muito genéricas, impondo ao poder de polícia um esvaziamento de seu sentido. ${ }^{193}$

Estes argumentos, com o devido respeito, não nos convencem.

Em primeiro lugar, a que se ponderar que, levando em conta que todas as atividades administrativas são exercidas em obediência a determinação legal

\footnotetext{
${ }^{190}$ BEZNOS, Clóvis, Poder de Polícia, Revista dos Tribunais, São Paulo, 1979, p. 47.

${ }^{191}$ GORDILLO, Augustin A., Tratado de Derecho Administrativo, Parte Geral - Tomo II, Editores MacchiLopez, Buenos Aires, 1975, p. 12.

192 FIGUEIREDO, Lúcia Valle, Curso de Direito Administrativo, 9a edição, Malheiros, São Paulo, 2008, p. 290.

${ }^{193}$ GORDILLO, Augustin A., Tratado de Derecho Administrativo, Parte Geral - Tomo II, Editores MacchiLopez, Buenos Aires, 1975, pp. 8/11.
} 
(princípio da legalidade no direito administrativo), nenhuma atividade mereceria outra designação que não fosse a de ato administrativo.

Assim, a discussão sobre a noção de poder de polícia e sua inclusão dentre os demais atos da Administração não guarda qualquer valor verdadeiramente relevante. Conforme já defendia Cassagne ${ }^{194}$ o estudo das situações envolvendo os atos de polícia extrapola o âmbito da teoria geral do ato administrativo. Fato é que, lato sensu, toda a atividade praticada por agente público é ato da Administração, porém, strito sensu e por razões metodológicas e científicas, os atos administrativos são nomeados e estudados de acordo com a nomenclatura consagrada pela doutrina, a fim de que reste um mínimo de sistematização ao estudo deste ramo do direito.

O que nos chama a atenção é o fato de que, mesmo em tempos em que o Estado Democrático de Direito tornou-se uma realidade irreversível, críticas como estas ainda surtam efeito, como se o instituto ou seu exercício pudessem em algum momento extrapolar os limites que a legalidade impõe.

Ouso aqui utilizar em defesa do instituto as palavras de Otto Mayer $^{195}$, que já em 1950, após relembrar que o poder de polícia, assim como as demais atividades do Estado estão seguramente submetidas à Constituição e aos princípios que regem o direito questionou de modo contundente:

" Por que, entonces, se esfuerzan los juristas, aun después de iniciada la época constitucional, em limitar em todo posible esta nocíon?

¿Cuál es el motivo de sus aprensiones especieales com respecto a esta mafestación de la voluntad del Estado, apesar de ser tan necesária?

¿El Estado de regímen constitucional y el de regimén de derecho no tienen a su disposición todas las formas necesarias para conciliar las exigência del bienestar público y de la liberdad individual* "

De fato, ou temos segurança de que são solidas nossas instituições ou por certo, precisamos fortalecê-las. Na verdade, as críticas apresentadas, a despeito do brilho inquestionável de seus patronos, acabam pecando pela excessiva carga ideológica de que vêm impregnadas.

${ }^{194}$ CASSAGNE, Juan Carlos, Derecho Administrativo, 6 ${ }^{\text {a }}$ Ed., Abeledo-Perrot, Buenos Aires, 2000, p. 451. ${ }^{195}$ MAYER, Otto, Derecho Administrativo Alemán, Ed. Depalma, Buenos Aires, 1950, p. 09.

* O autor se utilizava deste questionamento justamente para posicionar-se contrário a noção de poder de polícia, daí nossa ousadia em usar suas palavras para defender o instituto. 
Faz-se necessário desvincular a visão do poder de polícia das noções eivadas de preconceitos, uma vez que a questão, ao contrário do que fazem crer as críticas mais enfáticas, é de relevante interesse a preservação da liberdade e ao sadio exercício dos direitos individuais. ${ }^{196}$

$\mathrm{Na}$ verdade, ao contrário do que defendem os autores mencionados, o que se nota é a expansão das atividades de polícia do Estado em função do aumento da complexidade da vida moderna, aumentando exponencialmente a importância do instituto e a necessidade de um estudo balizado do mesmo.

Ao invés de diluído, o poder de polícia, com a evolução da vida em sociedade e de suas exigências, experimentou forte aumento de sua importância e de sua área de abrangência, porém, sem prejuízo de sua consistência. ${ }^{197}$

Não vale o argumento de que este avanço do poder de polícia ocasionou seu uso de modo aleatório e desmedido como alguns acreditavam que ocorreria. Contatou-se que com o fortalecimento do Estado de Direito, tal poder deixou de se sustentar num suposto "dever geral" dos indivíduos de respeitar a ordem ou num "domínio eminente do Estado", para emanar diretamente do princípio a legalidade, sem perder de vista o incremento dos direitos e garantias individuais.

O próprio Gordillo ${ }^{198}$ ponderou que não se deveria estabelecer como princípio a coação e o poder estatal para em seguida limitar estes poderes em função dos direitos individuais. Para ele o processo deveria ser inverso, ou seja, o sistema constitucional deveria estruturar-se positivamente "Estado de Direito", estabelecendo como princípio geral os direitos individuais e, nas hipóteses concretas, aplicar as restrições à estes direitos com base em legislação vigente, produzindo a coação estatal necessária (o exercício do poder de policia).

Esta é justamente a situação que vivenciamos hoje, sem que se imagine que restou sepultada a função de poder de polícia.

Por outro lado, a crítica no sentido de que o poder de polícia não corresponde a uma função exclusiva da Administração, formulada por Gordillo, também não se sustenta. É cediço que a divisão de Poderes proposta por Montesquieu não pode ser tomada de forma estanque, sendo fato que os "Poderes instituídos" desempenham funções

\footnotetext{
${ }^{196}$ FERREIRA, Daniel, Poder de Polícia, in Curso de Direito Administrativo, Marcelo Harger (org.) Ed. Forense, Rio de Janeiro, 2007, p. 353.

${ }^{197}$ MEDUAR, Odete, Direito Administrativo Moderno, $3^{\text {a }}$ ed., São Paulo, 1999, p. 366.

${ }^{198}$ GORDILLO, Augustin A., Tratado de Derecho Administrativo, Parte Geral - Tomo II, Editores MacchiLopez, Buenos Aires, 1975, p. 25.
} 
próprias e funções que lhes são excepcionais, não servindo para esvaziar a noção de poder de polícia o fato de que outros poderes eventualmente possam praticar atos desta natureza. $^{199}$

Enfim, se há alguma uma crise conceitual, não há que se falar em crise institucional. Conforme ensina Fiorini, a ciência jurídica precisa buscar mais profundamente qual o verdadeiro conteúdo do ato normativo de polícia do ponto de vista dogmático, concluindo que:.

"La atividad limitadora sobre los decrechos reconocidos que la policía realiza es el dato específico que la revela y la distingue de cualquier outra clase de actividad." ${ }^{200}$

Com efeito, o poder de polícia expressa de forma inconfundível e própria a necessidade de conformação da liberdade e do exercício dos direitos individuais, nos limites previstos em lei, com vistas a viabilizar a vida em sociedade. Em outras palavras, o poder de polícia é expressão de um dos mecanismos mais importantes de que dispõe a Administração Pública para manutenção do convívio social baseado no bem comum. $^{201}$

Resta superada a visão de um poder de polícia vinculado ao exercício arbitrário e marcadamente negativo do Estado, evoluindo-se para a idéia de um conjunto de ações ora restritivas, ora implementadoras de atividades, com vista a realização do bem-estar individual e/ou coletivo. ${ }^{202}$

Iara Leal Gasos enfrenta os argumentos que tentam vincular ao poder de polícia a ideia de despotismo com as seguintes considerações:

Se o objetivo principal é evitar a tirania do executivo, que a estrutura determine a interdependência e a especialização dos poderes. Porém, diante da emergência, diante da crise, a estrutura precisa ter a flexibilidade necessária para permitir o surgimento da providência urgente..$^{203}$

\footnotetext{
${ }^{199}$ BEZNOS, Clóvis, Poder de Polícia, Revista dos Tribunais, São Paulo, 1979, pp. 48.

${ }^{200}$ FIORINI, Bartolome, Poder de Polícia, Editora Alfa, Buenos Aires, 1962, pp. 12.

${ }^{201}$ MEDUAR, Odete, Direito Administrativo Moderno, $3^{a}$ ed., São Paulo, 1999, p. 366.

${ }^{202}$ JUSTEN FILHO, Marçal, Curso de Direito Administrativo, $3^{\text {a }}$ edição, Saraiva, São Paulo, 2008, p. 468.

203 GASOS, Iara Leal, A Omissão Abusiva do Poder de Polícia, Lumen Juris, Rio de Janeiro, 1994, p. 51.
} 
Ora, tal mecanismo não é outro senão o poder de polícia.

Em última análise, o poder de polícia modernamente deve ser enxergado como um modo especial de prestação de serviço em que o Estado se prepõe a conformar os direitos individuais ou coletivos, com vista a implementar o bem comum e assim, perpetrar um Estado de Direito isonômico.

Por este motivo, ficamos com a lição de Odete Medauar para quem:

A noção de "poder de policia" é a expressão teórica de um dos modos mais importantes de atuação administrativa, devendo ser mantida. ${ }^{204}$

\section{III.2 - Críticas à denominação: Poder de Polícia}

Não são poucos os autores que se dedicaram a apresentar ressalvas à denominação "poder de polícia" para designar a função administrativa que ora estudamos.

Para Bartolomé A. Fiorini ${ }^{205}$, tanto a expressão poder de polícia é equívoca quanto sua utilização é confusa.

Ele sustenta que é difícil para o direito moderno explicar o uso da expressão "poder de polícia" de modo autônomo, levando em conta a clássica divisão dos poderes. Ou a classificação tripartite não se sustenta quando se refere as atividades do Estado ou o poder de polícia não passa de força de expressão gramatical sem qualquer conteúdo jurídico.

Para o autor argentino, se essencialmente são três os poderes que compõem o Estado, o poder de polícia deve estar incluído em uma dessas atividades, expressando-se através de leis, atos administrativos ou sentenças. Sendo assim, para ele, juridicamente, o poder de polícia não passa de mais uma simples espécie de ato de direito público, não se diferenciando por seu objeto. Na essência, segundo ele, não é nem poder, nem polícia, pois expressa sempre relações jurídicas iguais as dos demais poderes estatais.

${ }^{204}$ MEDUAR, Odete, Poder de Polícia, in Boletim de Direito Administrativo, São Paulo, v. 12, $\mathrm{n}^{\circ}$ 12, p. 814-9, dezembro de 1996, p. 818.

${ }^{205}$ FIORINI, Bartolome, Poder de Polícia, Editora Alfa, Buenos Aires, 1962, pp. 09/11. 
Para Augustin A. Gordillo ${ }^{206}$, muito embora as expressões “polícia" e "poder de polícia" estejam entre as mais utilizadas em Direito Administrativo, não se tem um claro entendimento de seu significado e fundamentos.

Gordillo chega mesmo a afirmar que a noção de poder de polícia é tão nociva que pode se transformar na "sepultura de la liberdad", motivo pelo qual devese evitá-la, desfazendo-se do apego ortodoxo. Em sua visão, o abandono da ideia de poder de polícia diminui a possibilidade de que a Administração atue sem fundamentação legal. $^{207}$

Enterría e Fernándes fazem opção clara pelo abandono da expressão poder de polícia, preferindo denominar esta função de "actividad administrativa de limitación de derechos”, assim como já havia procedido Santi Romano na doutrina Italiana. $^{208}$

Celso Antônio Bandeira de Mello ${ }^{209}$ caminha no mesmo sentido. Segundo ele, a expressão "poder de polícia" além de equivoca é "manifestamente infeliz". Em sua visão, seria equivoca porque engloba em si atividades absolutamente distintas, a saber, as leis e os atos administrativos. Por outro lado seria infeliz por levar a crer muitas vezes, que o Estado possui poderes que de fato são absolutamente incompatíveis com o Estado de Direito. ${ }^{210}$

Na mesma linha dos mestres apontados acima, Dinorá Adelaide Grotti $^{211}$ afirma que o poder de polícia não pode ser considerado um verdadeiro poder, não passando de um "dever-poder" com o qual a Administração se vê impelida a atingir as finalidades impostas pelas normas do direito.

Também para Lucia Valle Figueiredo ${ }^{212}$ a expressão "poder de polícia" está totalmente superada. Para ela, o exercício do que se denomina "poder de

\footnotetext{
${ }^{206}$ GORDILLO, Augustin A., Tratado de Derecho Administrativo, Parte Geral - Tomo II, Editores MacchiLopez, Buenos Aires, 1975, p. 01.

${ }^{207}$ GORDILLO, Augustin A., Tratado de Derecho Administrativo, Parte Geral - Tomo II, Editores MacchiLopez, Buenos Aires, 1975, p. 25.

${ }_{208}$ ENTERría, Eduardo Garcia de, e FERNANDÉz, Thomás-Ramón. Curso de Derecho Administrativo, $4^{\text {a }}$ Ed., Vol II, Civitas, Madri, 1997, p. 108.

${ }^{209}$ BANDEIRA DE MELlO, Celso Antônio, Curso de Direito Administrativo, Malheiros, $21^{\text {a }}$ Ed., São Paulo, 2006, p. 779.

${ }^{210}$ No mesmo sentido: GRAU, Eros Roberto, Poder de Polícia: Função Administrativa e Princípio da Legalidade: O Chamado "Direito Alternativo", Revista Trimestral de Direito Público, n 01/1993, Editora Malheiros, p. 94.

${ }^{211}$ GROTTI, Dinorá Adelaide Musetti, Poder de Polícia - Palestra proferida no Seminário Nacional de Direito Administrativo - Edição Comemorativa dos 20 anos da NDI, BDS/Boletim de Direito Administrativo, 7/753-758, Ed. Nova Dimensão Jurídica, Junho 2006, p. 754.

${ }^{212}$ FIGUEIREDO, Lúcia Valle, Curso de Direito Administrativo, $9^{\mathrm{a}}$ edição, Malheiros, São Paulo, 2008, p. 290.
} 
polícia” se confunde com as demais atividades administrativas, que só podem ser estabelecidas pode lei, não havendo razão para se referir a estes atos como se fossem manifestações de um poder.

Mais recentemente Luis Manoel Fonseca Pires ${ }^{213}$, sustentou que a história do poder de polícia, ligada a arbitrariedade e a uma discricionariedade apartada da lei são motivos mais do que suficientes para o abandono da expressão "pode de polícia". Para ele a confusão entre poder de polícia e poder punitivo milita em desfavor da utilização da expressão. Seu caráter equívoco, que muitas vezes passa a ideia de um poder ilimitado, de liberdade para utilização da força, também não animam o autor a usar da terminologia clássica.

Segundo esta visão, mesmo tendo prevalecido a expressão antiga em tempos modernos, tal prevalência é efêmera, pois o poder é sempre expressão de uma competência fixada por lei, e a polícia, um conteúdo definido pelo direito.

Do mesmo modo, um dos mais ardorosos críticos atuais da expressão "poder de polícia”, Carlos Ari Sundfeld ${ }^{214}$ entende que a expressão traz em si, uma idéia de autoritarismo, que vem se tentando evitar, por exemplo, com a exclusão da expressão "poder", designando a atividade simplesmente como polícia administrativa.

Para ele o uso da expressão "poder" de polícia parece levar a crer que o Estado possui a prerrogativa implícita de fazer valer seu poder de "ordenação" mesmo em casos não estabelecidos por lei, podendo se utilizar dos instrumentos que reputar necessários para tanto, noção que afronta a ideia de Estado democrático de Direito.

Ainda segundo Sundfeld ${ }^{215}$, a expressão "poder de polícia" foi cunhada para o ambiente de um Estado mínimo, não abrangendo a interferência na economia, por exemplo, tendo como fim a proteção à propriedade. Ainda segundo o autor, modernamente, a atividade em questão não se restringe a limitações impostas ao Estado, alcançando também, no Estado Social, a imposição de condutas sociais e coletivas em busca do desenvolvimento nacional e de objetivos coletivos como a extinção da pobreza, redução das desigualdades, proteção ao patrimônio histórico, entre outras.

O autor entende que seria necessário eliminar a expressão poder de polícia por ser incompatível com Estado de Direito, pois, a ordenação das atividades da sociedade é mera expressão da vontade da lei, não podendo ser confundida com poder.

${ }^{213}$ PIRES, Luis Manuel Fonseca, Limitações Administrativas à Liberdade e à Propriedade, Quartier Latin, São Paulo, 2006, pp. 152/155.

${ }^{214}$ SUNDFELD, Carlos Ari, Direito Administrativo Ordenador, Malheiros Editores, São Paulo, 2003, p. 11.

${ }^{215}$ SUNDFELD, Carlos Ari, Direito Administrativo Ordenador, Malheiros Editores, São Paulo, 2003, p. 14. 
Eros $\mathrm{Grau}^{216}$ vai ainda mais longe ao sustentar que o poder de polícia sequer é uma prerrogativa, consubstanciando-se em mera função da Administração.

Com o devido respeito, os argumentos apresentados, muito embora enfáticos, mais uma vez não nos convencem.

Já há muito se consagrou a noção, agora prevista constitucionalmente (art. $1^{\circ}, \S$ único) de que todo poder emana do povo e em seu nome é exercido. neste sentido que a expressão "poder" deve ser interpretado e aplicado.

Por óbvio, no Estado de Direito a noção de poder só pode ser tomada como a potestade (investidura/competência/potencial) atribuída e exercida nos limites em que é conferido (função). A aversão ao termo "poder” parece limitar-se apenas ao repúdio aos períodos em que o poder tinha origem despótica e não raro, era a mais execrável expressão da tirania.

No entanto, do ponto de vista científico, o que deve ser analisado (e se for o caso rechaçado) é a origem (legítima ou despótica) e o exercício do poder (legal ou com abuso ou desvio de poder) e não o poder em si que, tendo coerência com os princípios do Estado de Direito é o fundamento do próprio Estado.

O exercício da vontade legal pelo Estado, dentro dos limites ali estabelecidos, não é outra coisa senão o exercício de poder emanado do povo e, com o devido respeito, a tentativa de alterar a nomenclatura para "direito administrativo ordenador", ou "restrição à propriedade e à liberdade", não passa de eufemismo ou metonímia, pois, somente com o exercício de supremacia, portanto de poder, é que é possível ao Estado ordenar a vida em sociedade, restringindo o exercício da propriedade, da liberdade e dos demais direitos consagrados.

Substituir o nome do instrumento (poder de polícia) por sua conceituação ou pela descrição de seu modo de desempenho ou objetivo não lhe altera a essência, podendo inclusive, dar causa a uma indevida limitação de seu verdadeiro alcance, promovendo ainda dificuldades quanto ao seu reconhecimento da parte dos leitores e profissionais não especializados no assunto.

Por óbvio, não se pode confundir o poder de polícia com o poder político. O poder político remete aos Poderes do Estado e é conferido pela Constituição de forma privativa a determinados Órgãos. Já o poder de polícia, está inserido entre os

${ }^{216}$ GRAU, Eros Roberto, Poder de Polícia: Função Administrativa e Princípio da Legalidade: O Chamado “Direito Alternativo", Revista Trimestral de Direito Público, nº 01/1993, Editora Malheiros, p. 95. 
poderes administrativos e, por natureza, é distribuído por toda a Administração, traduzindo-se numa função vital ao bom funcionamento da sociedade. ${ }^{217}$

O que é preciso ter claro é que a designação "poder” de polícia não pode ser concebido de outro modo, a não ser como uma expressão de uma função do Estado. Esta é a sua acepção científica.

Podemos constatar tal afirmativa nas lições de Santi Romano que explica de modo cristalino:

“ m gruppo importantisimo di poteri pubblici, che me costituisce anzi la categoria più importante, sono quelli che si designamo col di funzioni. Le funzioni (<<officia $>>$, <<munera $>>)$ sono i poteri che si esercitano non per um interesse próprio, o almeno esclusivamente próprio, ma per um interesse altrui o per um interesse oggetivo."218 (grifei)

Se o particular não reconhecer no Estado o poder (função) de exigir condutas que limitam as liberdades aos ditames legais, fatalmente toda a atividade ordenadora ou restritiva estatal será inócua.

Robert Dahl também não faz rodeios:

Chamamos em geral a influência desse tipo, em que há sanções severas para o não-cumprimento, de poder. ${ }^{219}$

$\mathrm{Na}$ verdade, o próprio Carlos Ari Sundfeld não destoa deste raciocínio. Ao explicar que as regras são imprescindíveis a quaisquer grupos o renomado mestre assim se posiciona em relação ao sentido da expressão "poder”:

Para existirem tais regras, alguma força há de produzi-las; para permanecerem, alguma força deve aplicá-las, com a aceitação dos

${ }^{217}$ MEIRELLES, Hely Lopes, Direito Administrativo Brasileiro, $17^{\text {a }}$ ed., Malheiros Editores, São Paulo, 1992.

${ }^{218}$ ROMANO, Santi, Principi di Diritto Constitucionale Generale, Ed. Giufrè, Milano, 1947, p. 111.

${ }^{219}$ DAHL, Robert Alan, Análise Política Moderna, Ed. Universidade de Brasília, Brasília, 1981, p. 39. 
membros do grupo. A essa, que faz as regras e exige o seu respeito, chama-se poder. ${ }^{220}$

Em outra ocasião, coerente ao posicionamento mencionado, Sundfeld ${ }^{221}$, ao apresentar a sua visão de administração ordenadora, não escapa de fazer alusão ao "emprego do poder de autoridade , não conseguindo, portanto, fugir do fato de que a atividade ordenadora nada mais é do que o exercício do "poder" atribuído pela lei.

Sempre com o devido respeito à opinião dos autores citados, carece de embasamento científico a proposta de mudança de denominação "poder polícia" do Estado, pairando as críticas na esfera do comprometimento histórico do uso da expressão consagrada.

De notar-se que apesar de todas as críticas que apresenta, o próprio Luis Manoel Fonseca Pires confessa que a expressão é alvo de evidente carga de preconceitos. $^{222}$

É preciso, pois, libertar a concepção do poder de polícia e a idéia que ela projeta dos preconceitos que a cercam, pois a simples mudança de nomenclatura poderá não isentar a nova designação das críticas.

Cabe aqui perfeitamente a lição de Carlos Maximiliano no sentido de que não se poder impor uma exegese (no caso a interpretação de que o poder de polícia remete sempre a uma conduta arbitrária) com base em teses pelas quais o hermeneuta se apaixonou:

...de sorte que vislumbra no texto ideias apenas existentes no próprio cérebro, ou no sentir individual, desvairados por ojerizas e pendores, entusiasmos e preconceitos. 223

É a opção que fez, por exemplo, Heraldo Garcia Vitta ${ }^{224}$, que em obra recente dedicada exclusivamente ao tema, após apresentar as principais críticas doutrinárias à expressão decidiu mantê-la em seu trabalho declarando que:

${ }^{220}$ SUNDFELD, Carlos Ari, Fundamentos de Direito Público, $4^{\mathrm{a}}$ ed., Malheiros Editores, São Paulo, 2009, p. 20.

${ }^{221}$ SUNDFELD, Carlos Ari, Direito Administrativo Ordenador, Malheiros Editores, São Paulo, 2003, pp. $16 / 17,20$ e 25 .

${ }_{222}$ PIRES, Luis Manuel Fonseca, Limitações Administrativas à Liberdade e à Propriedade, Quartier Latin, São Paulo, 2006, p. 156.

${ }^{223}$ MAXIMILIANO, Carlos, Hermenêutica e Aplicação do Direito, 19a Ed., Ed. Forense, Rio de Janeiro, 2010, p. 84. 
Realmente, a expressão, ao menos no Brasil, ajusta-se à análise formaldogmática.

$\mathrm{Na}$ literatura estrangeira podemos colher o entendimento de Juan Carlos Cassagne ${ }^{225}$, que, após apontar certa margem de dúvida a respeito do emprego da expressão "poder de polícia" acabou por confessar que não vislumbrava qualquer problema na continuidade de sua utilização.

Com efeito, a análise jurídica precisa ter a virtude de separar os valores antigos e os interesses políticos que impregnam a expressão "poder de polícia" e fazer com que aflore a "substância nobre" ali existente. ${ }^{226}$

A manutenção da expressão "poder de polícia" se justifica na medida em que, com ela, se pretende qualificar de modo específico uma classe de atividade, com um conteúdo permanente e exclusivo, ou seja, uma forma de classificação científica e consagrada.

Ora, a atuação do Estado nas mais variadas áreas não modifica a natureza desta atividade, que continua sendo "poder de polícia", no sentido de impor contornos ao exercício das liberdades inerentes a estas atividades e ao uso da propriedade num contexto em que sua função social ganha relevância.

Entre os autores brasileiros consagrados, a grande defesa da manutenção da expressão "poder de polícia" é realizada por Odete Medauar para quem:

Não parece adequado alterar o título de noções jurídicas consolidadas, mesmo que seu conteúdo sofra evolução. A mudança dificulta a pesquisa nas obras e dificulta pesquisa jurisprudencial. E também impede a percepção clara da linha evolutiva da figura. ${ }^{227}$

Para a professora, a preocupação dos autores que sustentam a tese de que a noção de poder de polícia se diluiu, perdendo seu sentido, parece estar baseada no temor da implementação de um poder de polícia de conteúdo e limites indeterminados,

${ }^{224}$ GARCIA VITTA, Heraldo, Poder de Polícia, Malheiros Editores, São Paulo, 2010, p. 20/21.

225 CASSAGNE, Juan Carlos, Derecho Administrativo, 6 ${ }^{\mathrm{a}}$ Ed., Abeledo-Perrot, Buenos Aires, 2000, pp. $449 / 450$.

${ }^{226}$ FIORINI, Bartolome, Poder de Polícia, Editora Alfa, Buenos Aires, 1962, p. 11.

${ }^{227}$ MEDUAR, Odete, Direito Administrativo Moderno, $3^{\mathrm{a}}$ ed., São Paulo, 1999, p. 
fundamentados num certo dever geral de respeito à ordem que acaba por permitir arbitrariedades e o totalitarismo.

No entanto, no estágio em que se encontra o Estado de Direito, solidamente fixado e fundamentado na lei como norteadora dos atos administrativos, com ênfase aos direitos individuais, não parece justificável tal preocupação. ${ }^{228}$

${ }^{228}$ MEDUAR, Odete, Poder de Polícia, in Boletim de Direito Administrativo, São Paulo, v. 12, nº 12 , p. 814-9, dezembro de 1996, p. 817. 


\section{IV - DAS TRANSFORMAÇÕES NO ESTADO E OS REFLEXOS NO PODER DE POLÍCIA.}

\section{IV.1 - Do Estado absoluto ao Estado de Direito.}

Antes de qualquer abordagem a respeito da evolução experimentada pelo Estado ao longo do tempo, é oportuno aclararmos que a noção de "Estado" é relativamente nova, se aplicando ao passado remoto apenas por projeção. Assim, quando nos referimos a Estado grego ou romano, estamos projetando uma ideia atual a uma conjuntura em que tal noção era absolutamente desconhecida.

Segundo o professor Sérgio Resende de Barros ${ }^{229}$ o termo "Estado" só passou a ser utilizado na transição da Idade Média para a Idade Moderna. Somente no Século XVI, com a dicotomia entre a política e a economia, é que a noção de Estado retroage sobre as formações políticas anteriores, definindo-os.

Para Norberto Bobbio ${ }^{230}$, foi a grande influência do "Príncipe" de Maquiavel, que consagrou e difundiu a expressão "Estado".

A designação: "Estado" foi engendrada na Idade Média para definir a forma de organização política que no mais das vezes inexistia no "passado clássico",231

Já a expressão "Estado de Direito", surgiu na Alemanha. Rechtsstaat, de Recht (direito) e Staat (Estado). Foi cunhada por John Wilhelm Placidus em 1798 (muito embora Friedrich Auguste Hayek afirme que o termo surgiu com K. T. Welcker na obra Die letzeten Gründe no Recht. Staat um Strafe - Guiessenm 1.813) ${ }^{232}$

Jean Rivero $^{233}$ aponta com precisão que a expressão Rechtstaat, na terminologia alemã, foi empregada justamente em contraposição à ideia de Polizeistaat,

\footnotetext{
${ }^{229}$ BARROS, Sérgio Resende de, Contribuição Dialética para o Constitucionalismo. Millenium, Campinas, SP, 2007, p. 36.

${ }^{230}$ BOBBIO, Norberto, Estado, Governo, Sociedade - Para uma teoria geral da política, $4^{\mathrm{a}}$ ed., Editora Paz e Terra, Rio de Janeiro, 2007, p. 65.

${ }^{231}$ FERREIRA FILHO, Manoel Gonçalves, Aspectos do Direito Constitucional Contemporâneo, $2^{\mathrm{a}}$ ed., Saraiva, São Paulo, 2009, p. 04.

${ }^{232}$ Neste sentido: BARROS, Sérgio Resende de, in: "Estado de Direito" - Texto integrante do curso "A negação do Estado de direito pelo Estado de legalidade - Curso de Pós Graduação da Faculdade de Direito da USP-SP, $2^{\circ}$ semestre de 2010, p. 3.

${ }^{233}$ RIVERO, Jean, Curso de Direito Administrativo Comparado, Apostila, Tradução José Cretella Jr., Editora Revista dos Tribunais, São Paulo, 2004, pp. 158/159.
} 
numa flagrante apologia à máxima: "Tu patere legem quem fecisti" em detrimento da idéia de que: "Princeps solvitur lege".

Realizado este breve esclarecimento, interessa-nos no momento, verificar como se processou a mudança do Estado absoluto para o Estado de Direito, em que a Lei passou a ser considerada a expressão da vontade geral e soberana.

Com a queda do império romano, provocado pelas invasões bárbaras, por volta do século $\mathrm{V}$ da Era Cristã, surgiu o que se denominou de Estado Medieval, marcado pela substituição das tradições romanas pela nova forma de vida imposta pelos germânicos.

Neste período a percepção de Estado (no caso absoluto) praticamente desapareceu num primeiro momento, tendo em vista a devastação causada pelos invasores, ressurgindo num modelo que mais tarde, paulatinamente, iria se voltar ao resguardo dos direitos do homem e a liberdade individual.

Para poderem perpetuar suas conquistas, os "reis bárbaros" promoveram uma grande distribuição de terras entre os chefes guerreiros, produzindo uma forçosa divisão de poder e criando uma nobreza submissa ao rei, que veio a ser conhecida como senhores feudais.

Dentro de suas terras os senhores feudais agiam como soberanos absolutos, produzindo suas próprias leis e justiça, em detrimento dos vassalos que praticamente viviam sem quaisquer direitos, submissos aos senhores que se sucediam hereditariamente.

Reagindo contra tal opressão, os indivíduos procuraram se abrigar no refúgio no Estado que, com isto, novamente se fortaleceu em face dos senhores feudais, voltando a centralizar o poder.

Este movimento do povo em direção ao poder central e o concomitante enfraquecimento do poder papal fez com que as monarquias medievais fossem gradativamente substituídas, desta vez pelas chamadas monarquias absolutas.

Procurando se distanciar da Igreja e fortemente influenciados pelo humanismo renascentista, os monarcas absolutos envidaram forças para concentrar o poder como forma de preservar a unidade do Estado nacional. A despeito do distanciamento relativo em relação ao clero, o poder dos monarcas era fundamentado no direito divino dos reis, que provinha diretamente de Deus e, portanto, não poderia ser contrastado. ${ }^{234}$

${ }^{234}$ MALUF, Sahid, Teoria Geral do Estado, $28^{\circ}$ ed., Saraiva, São Paulo, 2008, pp. 115 e seguintes. 
Conforme registra Sahid Maluf:

As monarquias absolutas, desconhecendo qualquer limitação do poder, chegaram a reduzir a idéia de soberania a um conceito simplista de senhoria real, próprio do mundo feudal (o Rei, individualmente, é o proprietário do Estado). Assim como a propriedade é direito exclusivo do dono sobre a coisa, o poder de imperium é direito absoluto do Rei sobre o Estado. A partir da segunda metade do século XVI, o poder real assume, desta forma, o duplo conceito: de senhoriagem, próprio do feudalismo, e de imperium na sua significação extremada que lhe davam os antigos imperadores romanos. ${ }^{235}$

Mais uma vez reagindo contra a opressão desmedida e influenciados pelas ideias de liberdade disseminadas por expoentes como Hobbes, John Locke e Montesquieu, os indivíduos passaram a aspirar a conquistas de direitos e garantias individuais contra o arbítrio do soberano, pugnando pelo reconhecimento de direitos que passaram a ser entendidos como naturais, especialmente em relação à propriedade.

Tal reação culminaria com a implantação do liberalismo e com o surgimento do Estado de Direito de natureza anti-absolutista.

O Estado de Direito surge, portanto, fundamentado no chamado direito natural, ou seja, nos direitos considerados inerentes a pessoa humana, que precedem a formação do Estado. A razão de ser do direito, segundo o pensamento dominante à época, deveria ser a valorização do indivíduo e o respeito à sua individualidade. ${ }^{236}$

Com efeito, na segunda metade do século XVII, com a ocorrência da chamada Revolução Gloriosa (1689), teve início um movimento intelectual e político que visava impor limites ao absolutismo na Inglaterra. Começa a vicejar o constitucionalismo que, acreditava-se, viria em socorro contra os desmandos despóticos, equilibrando a sociedade que veria o direito dos mais fracos inscritos num Canon a ser observado, inclusive pelo próprio Estado, o que se constituía em excelente novidade. ${ }^{237}$

O final do século XVIII é marcado tanto pela da Revolução Americana (1776) quanto pela Francesa (1789), e o constitucionalismo ganha novo ânimo

\footnotetext{
${ }^{235}$ MALUF, Sahid, Teoria Geral do Estado, $28^{\circ}$ ed., Saraiva, São Paulo, 2008, p. 128.

${ }^{236}$ PIRES, Luis Manuel Fonseca, Limitações Administrativas à Liberdade e à Propriedade, Quartier Latin, São Paulo, 2006, p 141.

${ }^{237}$ FERREIRA FILHO, Manoel Gonçalves. Princípios Fundamentais do Direito Constitucional, Saraiva, São Paulo, 2009, pp. 3 e 4 ..
} 
com o surgimento do poder constituinte, que trouxe legitimidade ao processo. Com ênfase no estabelecimento de um "Estado das leis e não dos homens" ganha força o liberalismo que, para garantir as liberdades, alça a separação dos poderes e a previsão dos direitos fundamentais do homem ao nível constitucional ${ }^{238}$.

A lei passa ser a portadora da vontade geral, sendo consideradas legítimas tão somente as emanações legais e não mais a mera vontade do príncipe, como no "Estado de Polícia".

Surge neste contexto o princípio da legalidade, tornando lícito tão somente aquilo que a vontade popular, manifestada através da lei, por meio de seus representantes assim instituía. ${ }^{239}$

Foi justamente neste período que as formações sociais tradicionais deram lugar a organizações mais complexas, em que o poder é transferido a uma autoridade central incorporado pelo Estado. Justamente no ponto de intersecção entre estes sistemas é que se situa a ordem legal, regulando, além dos meios de produção, o "exercício estratégico do poder", que exige legitimação. ${ }^{240}$

Não há mais que se falar em arbitrariedade do poder central ou da soberania do príncipe que agora só atua na forma estabelecida em lei, ao mesmo tempo em que se reconhecem como invioláveis determinados direitos que se põem a salvo da intervenção estatal.

\section{Segundo Fiorini:}

"Este es el llamado Estado gendarme, que se le define como aquel que reduce totalmente la actividad policial, puesto, que el individuo es el poder más amplio y seguro para conquistar todas y cualquiera de sus satisfactiones. ${ }^{241}$

Vale a nota de que neste período, o que se busca proteger acima de tudo é o direito de aquisição de propriedade. Qualquer ingerência nesta seara é considerada arbitrariedade. A atividade policial assim é reduzida aos governos e atividades locais, concentrando-se na ordem e na tranquilidade pública.

\footnotetext{
${ }^{238}$ MENDES, Conrado Hübner, Controle de Constitucionalidade e Democracia, Elsevier, Rio de Janeiro, 2009, p.6.

${ }^{239}$ PIRES, Luis Manuel Fonseca, Limitações Administrativas à Liberdade e à Propriedade, Quartier Latin, São Paulo, 2006, p. 142.

${ }^{240}$ HABERMAS, Jürgen, A Crise de Legitimidade no Capitalismo Tardio, Edições Tempo Brasileiro, Rio de Janeiro, 1999, p. 26.

${ }^{241}$ FIORINI, Bartolome, Poder de Polícia, Editora Alfa, Buenos Aires, 1962, p.45.
} 
Caio Tácito retrata bem este período destacando a restrição do campo de atuação do Poder Público, de forma que:

A ação do Estado visa facilitar e garantir o livre jogo dos negócios, tendo como base jurídica a autonomia da vontade, em que se apóia a liberdade de contrato e associação. ${ }^{242}$

Mas todo este progresso teve seu preço. Se a propriedade e a liberdade ganharam relevância inaudita, estes mesmos direitos deram causa a constantes contendas entre os indivíduos, ao ponto de conduzi-los a ceder a plenitude natural destes direitos (Locke) na busca de outro relevante valor - a segurança social.

Nas palavras de Manoel Gonçalves Ferreira Filho:

Exatamente por causa desses conflitos é que os homens concordam em deixar a plena liberdade do estado de natureza, a fim de, sacrificando parcialmente os seus direitos naturais, obterem três coisas: leis que definam a aquisição e gozo da propriedade; um poder maior do que a força de cada indivíduo isolado que faça cumprir as leis - uma "força pública” enfim, juízes que dirimam os litígios, aplicando as leis. Essas três coisas são o objetivo a concretizar no estado social, o que claramente leva à concepção de um Estado com as funções de legislar, executar as leis e julgar segundo as leis. ${ }^{243}$

Os regulamentos surgiam, portanto, pela necessidade de convívio entre os direitos reconhecidos, sendo a polícia uma atividade necessária, manifestada pelo direito com vistas a evitar desequilíbrio. ${ }^{244}$

Ressurge então a idéia de poder de policia, agora sob nova ótica, não mais a serviço do soberano, mas como instrumento de ordenação da coletividade.

Tais características marcaram o denominado Estado liberal, em que os poderes do Estado foram limitados para que ganhasse força a proteção às liberdades individuais. O papel do Estado, no uso do poder de policia passa a ter característica

${ }^{242}$ TÁCITO, Caio, Temas de Direito Público (Estudos e Pareceres), Renovar, Rio de Janeiro, 1997, p. 377.

${ }^{243}$ FERREIRA FILHO, Manoel Gonçalves, Aspectos do Direito Constitucional Contemporâneo, $2^{\mathrm{a}}$ ed., Saraiva, São Paulo, 2009, p. 31.

${ }^{244}$ FIORINI, Bartolome, Poder de Polícia, Editora Alfa, Buenos Aires, 1962, p.46. 
marcadamente "negativa", no sentido de agir impedindo aç es tendentes a violar os restringir o exercício dos direitos individuais.

A noção liberal de poder de polícia era restrita, portanto, a de ação de impor limitação aos direitos, com a finalidade de proteger a segurança, a saúde e a moralidade públicas contra qualquer perigo. Era manifesto, como vimos, o caráter negativo de atividade de polícia do Estado. ${ }^{245}$ Tal realidade, que persistiu até o início do Século $\mathrm{XX}^{246}$

Mas havia aspectos negativos neste novo contexto. Paulo Bonavides, por exemplo, traduz este período da seguinte maneira:

Decorrente dessa posição filosófica, temos o Estado gendarme de Kant, o Estado guarda-noturno, que Lasalle tanto ridiculariza, demissionário de qualquer responsabilidade na promoção do bem comum. Este só se alcança quando os indivíduos se entregam à livre e plena expansão de suas energias criadoras, fora de qualquer estorvo de natureza estatal. ${ }^{247}$

Fato é que com o final do absolutismo, houve inegáveis avanços no que diz respeito à garantia aos direitos individuais. No entanto, tais avanços não foram capazes de assegurar de forma plena a erradicação das injustiças perpetradas muitas vezes pelos próprios agentes incumbidos de zelar justiça e pela correta aplicação o Direito.

Muito em razão disto, entre o final do século XIX e começo do século XX percebe-se uma nova transição, em que o Estado Liberal, voltado a atender as necessidades das classes dominantes, começa a ceder espaço para um novo modelo de Estado, em que o foco passa ser a atenção às necessidades das massas. ${ }^{248}$,

Tais transformações foram tomando forma na medida em que o Estado teve que reassumir papel de relevância na economia, para proteger o interesse coletivo da exploração desenfreada. O Estado também precisou atuar na implementação de serviços de utilidade pública, pois a iniciativa privada não produzia meios adequados para que todos se beneficiassem de tais serviços. A implacável exploração dos meios de

${ }^{245}$ GORDILLO, Augustin A., Tratado de Derecho Administrativo, Parte Geral - Tomo II, Editores MacchiLopez, Buenos Aires, 1975, p. 06.

${ }^{246}$ PIRES, Luis Manuel Fonseca, Limitações Administrativas à Liberdade e à Propriedade, Quartier Latin, São Paulo, 2006, pp. 142 e 143

${ }^{247}$ BONAVIDES, Paulo, Do Estado Liberal ao Estado Social, Malheiros Editores, $9^{\mathrm{a}}$ Ed., São Paulo, 2009, p. 40.

${ }_{248}$ MOREIRA NETO, Diogo de Figueiredo, Mutações do Direito Administrativo, $2^{a}$ ed., Renovar, Rio de Janeiro, 2001, pp. 38/40. 
produção também produziu uma forte reação dos proletários, fazendo surgir paulatinamente uma legislação tendente a equilibrar a relação de trabalho. ${ }^{249}$

Começavam a ruir as estruturas da "escola do direito natural da burguesia racionalista", que sucumbia frente às aspiraç es das demais classes. Nas precisas palavras de Paulo Bonavides:

O curso das idéias pede um novo leito. Da liberdade do Homem perante o Estado, a saber, da idade do liberalismo, avança-se para a idéia mais democrática da participação total e indiscriminada desse mesmo Homem na formação da vontade estatal. ${ }^{250}$

A par das questões político-sociais, o final do século XIX e início do século XX é marcado ainda pelos grandes confrontos bélicos de proporções globais, que acabaram por forçar a estatização da economia, produzindo uma mais acentuada desigualdade social. ${ }^{251}$

Como opções a este quadro fortemente conflituoso, surgem num primeiro momento os modelos do Estado do Bem-Estar Social e o Estado Socialista, focados nos meios de produção.

No entanto - conforme veremos de forma mais acurada mais a frente - mesmo estes novos modelos (do bem-estar social e o socialismo) se desgastaram rapidamente $^{252}$ e no período pós Segunda Guerra Mundial, embalada pelas novas tecnologias e com a mudança dos métodos de produção, ganhou força uma nova estrutura social "pluriclasse", ou seja, um modelo em que o Estado deixava de ser protagonista, cedendo este papel não apenas para o cidadão, já acolhido pelas garantias individuais, mas para a coletividade organizada e qualificada pela reunião de seus interesses.

Este pluralismo social e os conflitos entre os grupos, deles inerentes, produziram embates de interesses e não mais apenas conflitos de direitos, como no Estado Liberal. ${ }^{253}$

\footnotetext{
${ }^{249}$ TÁCITO, Caio, Temas de Direito Público (Estudos e Pareceres), Renovar, Rio de Janeiro, 1997, p. 378. ${ }^{250}$ BONAVIDES, Paulo, Do Estado Liberal ao Estado Social, Malheiros Editores, 9a Ed., São Paulo, 2009, p. 43.

${ }^{251}$ TÁCITO, Caio, Temas de Direito Público (Estudos e Pareceres), Renovar, Rio de Janeiro, 1997, p. 378.

${ }^{252}$ CRUZ, Paulo Márcio, Política, Poder, Ideologia e Estado Contemporâneo, $2^{\text {a }}$ ed., Juruá, Curitiba, 2002, p. 73.

${ }^{253}$ FERREIRA FILHO, Manoel Gonçalves, Aspectos do Direito Constitucional Contemporâneo, $2^{\mathrm{a}}$ ed., Saraiva, São Paulo, 2009, pp. 32/34.
} 
Essa verdadeira nova revolução é fortemente marcada pela explosão dos meios de comunicação e informática que contribuíram sobremaneira para que as culturas trocassem informações numa velocidade nunca antes vista, globalizando-se os mercados e as economias, produzindo irreversíveis e drásticas mudanças nas estruturas sociais por todo o planeta. ${ }^{254}$

Diante de tão profundas mudanças, obviamente foi necessário que a forma do exercício do Poder Público mais uma vez se modificasse. Conforme explica Eros Grau, neste novo Estado Democrático de Direito, o direito posto não legitima mais por si só o interesse e as aspirações sociais:

São as aspirações sociais e o interesse social que legitimam o direito. ${ }^{255}$

A democracia liberal começava a ser substituída pela democracia participativa na qual, aos padrões da lei, é somada a vontade popular através da participação política, em que os cidadãos deliberam sobre a forma como querem ser governados.

\section{Nas palavras de Moreira Neto:}

A participação e a consensualidade tornaram-se decisivas para as democracias contemporâneas, pois contribuem para aprimorar a governabilidade (eficiência); propiciam mais freios contra o abuso (legalidade). Garantem a atenção a todos os interesses (justiça); proporcionam decisão mais sábia e prudente (legitimidade); desenvolvem a responsabilidade das pessoas (civismo); e tornam os comandos estatais mais aceitáveis e facilmente obedecidos (ordem). ${ }^{256}$

Este pequeno resumo demonstra a preocupação histórica em perpetrar através de mecanismos legais um ambiente estatal em que houvesse o estabelecimento de um verdadeiro Estado de Direito, sendo eleito o regime constitucional como garantidor deste Estado.

${ }^{254}$ CRUZ, Paulo Márcio, Política, Poder, Ideologia e Estado Contemporâneo, 2ª ed., Juruá, Curitiba, 2002, pp. $74 / 75$.

${ }^{255}$ GRAU, Eros Roberto, O Direito Posto e o Direito Pressuposto, $7^{\mathrm{a}}$ ed., Malheiros, São Paulo, 2008, p. 88. ${ }^{256}$ MOREIRA NETO, Diogo de Figueiredo, Mutações do Direito Administrativo, $2^{\mathrm{a}}$ ed., Renovar, Rio de Janeiro, 2001, p. 41. 
Como vimos, o Estado evoluiu de um modelo em que os seus limites eram estabelecidos pelo soberano, tão somente fundamentado na força ou pela religiosidade que inspirava a moral vigente, passando por um modelo onde a legalidade é que fixava os parâmetros de atuação do Estado (Estado de Direito Liberal), até chegar ao Estado Democrático de Direito em que o limite da atuação estatal começa a ser indicado pela legitimidade que é obtida através do "consenso sócio-político"257 (participação e deliberação popular)

Acompanhando tal evolução, conforme veremos, aprimoraram-se a noção e a percepção a respeito do poder de polícia e os seus mecanismos de exercício. Nas palavras de Caio Tácito:

O poder de polícia, que é o principal instrumento do Estado no processo de disciplina e continência dos interesses individuais, reproduz, na evolução de seu conceito, essa linha ascensional de intervenção dos poderes públicos. ${ }^{258}$

\section{IV.2 - O Poder de Polícia no Estado de Direito.}

Como pudemos verificar, foi com o surgimento do Estado de Direito que o "Estado de Polícia" realmente cedeu espaço para um novo conceito de sociedade, onde o particular, por força de normas constitucionais, pode fazer valer seus direitos, inclusive contra o próprio Poder Público.

O Direito Público deste período, lastreado pelas novas ideias liberais-democratizantes, promoveu uma profunda limitação da noção de polícia, na exata medida em que ainda vicejava o sistema constitucional. ${ }^{259}$

Conforme registrou Cassagne ${ }^{260}$, a forte evolução verificada no próprio conceito original de Estado foi provocada pelas restrições aos poderes estatais e a limitação de sua abrangência.

José Afonso da Silva retrata com muita riqueza os pontos centrais da filosofia política implantada na época ao explicar que:

\footnotetext{
${ }^{257}$ MOREIRA NETO, Diogo de Figueiredo, Mutações do Direito Administrativo, $2^{\mathrm{a}}$ ed., Renovar, Rio de Janeiro, 2001, p. 40.

${ }^{258}$ TÁCITO, Caio, Temas de Direito Público (Estudos e Pareceres), Renovar, Rio de Janeiro, 1997, p. 522.

${ }^{259}$ MAYER, Otto, Derecho Administrativo Alemán, Ed. Depalma, Buenos Aires, 1950, p. 06.

${ }^{260}$ CASSAGNE, Juan Carlos, Derecho Administrativo, 6 ${ }^{\mathrm{a}}$ Ed., Abeledo-Perrot, Buenos Aires, 2000, p. 449.
} 
O Estado de Direito era um conceito tipicamente liberal; daí falar-se em Estado Liberal de Direito, cujas características básicas foram: (a) submissão ao império da lei, que era a nota primária de seu conceito, sendo a lei considerada como ato emanado formalmente do Poder Legislativo, composto de representantes do povo, mas do povo-cidadão; (b) divisão de poderes...; (c) enunciado e garantia dos direitos individuais... Estas exigências continuam a ser postulados básicos do Estado de Direito, que configura uma grande conquista da civilização liberal ${ }^{261}$

Esvaziando os poderes do príncipe e limitando ao máximo a intervenção estatal na atividade privada, neste período, a sociedade passou a entender como bem comum a proteção e a garantia da manutenção dos direitos agora conquistados.

Cassagne leciona que:

"Em esse cuadro, aparece el Estado de Derecho como representación de um modelo ideal de régimen característico de los derechos individuales que instituye um principio fundamental, a partir de cual se edifica el andamiaje jurídico de la protección de los particulares."262

Assim, sob a influência do liberalismo e, portanto, com grande ênfase na não intervenção estatal na esfera individual, qualquer interferência do Estado com vistas à limitação da liberdade ou propriedade era fortemente resistida, motivo pelo qual o poder de polícia neste primeiro momento do Estado de Direito era exercido de forma excepcional, restrito a garantia da segurança pública, toma em sentido muito específico. $^{263}$

Restava ao Estado tão somente a intervenção em momentos extremos em que a ordem pública estivesse em grave perigo. Cabia ao Estado, através da polícia, como já informado, a manutenção do trinômio: salubridade, da moralidade e da segurança; ficando adstrito a estes campos seu poder de coerção.

\footnotetext{
${ }^{261}$ SILVA, José Afonso da, Curso de Direito Constitucional Positivo, 22ª ed., Malheiros Editores, São Paulo, 2003, pp. 112/113.

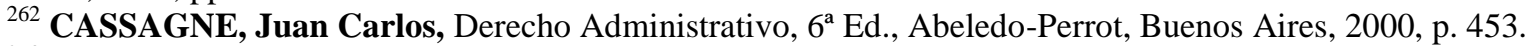

${ }^{263}$ DI PIETRO, Maria Sylvia Zanella, Direito Administrativo, Atlas, 20ª Ed., São Paulo , 2007, pp. 102 e 103.
} 
Diante deste quadro, o bem estar era considerado um valor a ser perseguido por cada indivíduo que, no uso da liberdade que lhe era atribuída por Deus, deveria buscar o atingimento de seus interesses particulares. ${ }^{264}$

Tendo neste período um caráter predominantemente preventivo, a atuação da polícia administrativa era manifesta através de limitações e proibições expressas por meio de atos de alcance geral - como as leis e normas abstratas; ou por meio de medidas concretas ou específicas - como a apreensão de material utilizado sem licença, fechamento de estabelecimentos, etc.

A grande diferença é que as limitações administrativas no Estado de Direito são levadas a efeito por força de lei e não mais por mera conveniência do Estado ou do governante. Resta a Administração, para aplicação destas normas, tão somente a fixação de parâmetros que são expressos através de Decretos, Portarias, etc, que têm a função de tornar viável a execução material, tanto da atividade preventiva (fiscalização, proibições, instruções), como repressiva (interdições, apreensões, etc,). ${ }^{265}$

\section{Conforme registraram Enterría e Fernándes:}

Deste modo, resulta excluida, sin vacilación, la possibilidade de que la Administración pueda imponer medidas limitativas de los derechos remitiéndose a su solo juicio ocasional, sin norma legal que ampare la medida. ${ }^{266}$

Com efeito, nosso sistema jurídico reflete fortemente este cenário, ou seja, o pensamento do Estado de Direito de influência liberal. Em razão disto, constatamos que só a lei pode impor uma ação ou restringir o exercício de uma atividade. O Poder Público, portanto, só pode exigir uma ação ou uma abstenção com base em uma lei que autorize tal conduta administrativa.

$\mathrm{O}$ art. $153, \S 2^{\circ}$ de nossa Constituição Federal é expressão inequívoca deste pensamento quando declara que:

\footnotetext{
${ }^{264}$ BEZNOS, Clóvis, Poder de Polícia, Revista dos Tribunais, São Paulo, 1979, p 16.

265 ARAÚJO, Edmir Netto de, Curso de Direito Administrativo, Saraiva, 5a Ed., São Paulo, 2010, pp. 1052 e 1053.

266 ENTERRÍA, Eduardo Garcia de, e FERNÁNDEZ, Thomás-Ramón. Curso de Derecho Administrativo, 4ª Ed., Vol. II, Civitas, Madri, 1997, p. 112.
} 
Ninguém será obrigado a fazer ou deixar de fazer alguma coisa senão em virtude de lei.

Dito em outras palavras, a ideia original propagada pelo Estado de Direito Liberal e albergada pelo direito pátrio é a de que ao particular é facultado fazer o que bem entender, salvo se houver lei que regule este direito, caso em que terá ensejo a oportuna ação da policia administrativa.

Outra característica clara da influência deste pensamento sobre o Direito Administrativo brasileiro está refletida no artigo 37 da Constituição de 1.988. Sendo um dos maiores artigos da Constituição, verificamos ali o esforço do legislador constituinte em estabelecer os princípios e o regime jurídico da atuação da Administração Pública, expondo limites claros para a atuação de seus agentes, estabelecendo a necessária proteção dos indivíduos frente ao Poder Público.

Tal concepção de Estado, a despeito do grande avanço, não trouxe a satisfação social desejada. Bem por isto, começaram a surgir mudanças na própria concepção de Estado de Direito, em que o poder de polícia passou a ser utilizado como instrumento de alcance maior do que a mera manutenção preventiva da ordem pública o do sossego coletivo. ${ }^{267}$

Com o fortalecimento e desenvolvimento das ideias liberais, as aspirações pelo exercício dos direitos individuais em detrimento dos poderes do Estado foram alçadas ao nível de princípios e sedimentadas nos textos constitucionais como vimos. Porém, se o Estado de Direito (liberal) é marcado pela valorização do indivíduo e de seus direitos, fato é que tais direitos e liberdades individuais também precisaram conhecer limites na lei, de modo a tornar possível a convivência com os demais indivíduos, impedindo a degeneração da organização para o caos, reclamando uma nova postura do Estado e do exercício do poder de polícia, com o que nos ocuparemos a frente. ${ }^{268}$

\footnotetext{
${ }^{267}$ MEDUAR, Odete, Direito Administrativo Moderno, $3^{\text {a }}$ ed., São Paulo, 1999, p. 365.

${ }^{268}$ SUNDFELD, Carlos Ari, Direito Administrativo Ordenador, Malheiros Editores, São Paulo, 2003, p. 09.
} 


\section{IV.3. - Do Estado Le al ou le alismo.}

Antes de abordarmos a questão do equilíbrio do exercício dos direitos individuais, cabe ainda uma palavra sobre um dos grandes problemas enfrentados pelo Estado de Direito Liberal - o "Legalismo".

A história demonstra como rapidamente os ideais insculpidos pelo liberalismo nas primeiras constituições se degeneraram pela ausência de mecanismos que perpetrassem as condições para que as classes oprimidas gozassem dos mesmos direitos que acudiam as classes dominantes.

Este fato histórico pode ser comprovado pelo surgimento, na França, do que se denominou de "L-Etat legal", numa demonstração clara do fortalecimento da ideia de supervalorização da Lei em detrimento do Direito.

Sérgio Resende de Barros $^{269}$ chama a atenção para o fato de que:

...justamente para evitar o Estado legalista, é que se deve promover o estudo crítico do Estado de legalidade em cotejo com o Estado de direito.

Isto porque, continua:

...no legalismo, a legalidade se torna realmente uma simples referência ritual. Dessa maneira o legalismo se propaga como ideologia mistificadora do próprio direito"

Em outras palavras, o legalismo irrefletido trouxe consigo o efeito indesejado da imposição da obediência cega à lei, promovendo a injustiça justamente pela negação ao direito. Sem levar em conta as consequências da aplicação mecânica da lei, o Estado legalista muitas vezes gerava uma a opressão disfarçada de proteção.

Diferente do "Estado Absoluto" ou "Estado de Polícia" que vimos anteriormente, o "Estado Legalista" utiliza de meios muito mais sutis para impor-se. Sob o manto da legalidade, o Estado legalista dissimuladamente desrespeita os direitos individuais, tornando-se arbitrário pela utilização e interpretação da lei de um modo que lhe é conveniente.

${ }^{269}$ BARROS, Sérgio Resende, in: Segundo Texto - Estado de Direito" - integrante do curso "A negação do Estado de direito pelo Estado de legalidade - Curso de Pós Graduação da Faculdade de Direito da USP-SP, $2^{\circ}$ semestre de 2010, pp. 2/12. 
O legalismo é, pois:

...a ideologia que aninha e esconde na forma da lei um conteúdo autocrático, tendente à indiferença social ou mesmo à injustiça social, não raro acompanhada de um elitismo jurídico antidemocrático. ${ }^{270}$

É preciso compreender corretamente a crítica que se faz aqui. Não se nega, obviamente, que a lei deva ser aplicada. Apenas se sustenta que a elaboração ou aplicação da lei não pode prescindir aos valores maiores da dignidade humana e de que são os interesses legítimos dos indivíduos que devem nortear a elaboração e aplicação das normas.

Dispensada a observância destes valores maiores, observa-se de forma não rara, o uso da própria lei para legitimação de condutas atrozes e de ditaduras desumanas ao longo da história, fazendo com que, mesmo sob a égide do Estado de Direito, o exercício do poder de polícia fosse marcado pelo abuso.

Foi Raymond Carré de Malberg ${ }^{271}$ em sua obra "Contribution à la Theorie Génerale de L'État" o primeiro a identificar o fenômeno do legalismo estatal. Na época, a crítica do mencionado autor limitava-se França pós Primeira Guerra e justamente ao âmbito do Direito Administrativo praticado pelo Estado Francês.

Malberg identificou que apesar de apresentar-se como um Estado de Direito, a França não passava de um "Estado legalista", pois a atividade administrativa, por força da Constituição de 1785, era meramente uma atividade executora cega da lei, sem levar em conta o direito do cidadão.

Segundo Malberg:

...o Estado de direito é estabelecido simplesmente e unicamente no interesse e para salvaguarda dos cidadãos; ele não tende senão a assegurar a proteção do seu direito ou do seu estatuto individual.

\footnotetext{
${ }^{270}$ BARROS, Sérgio Resende de, in: "Estado de Direito" - Texto integrante do curso "A negação do Estado de direito pelo Estado de legalidade - Curso de Pós Graduação da Faculdade de Direito da USP-SP, $2^{\circ}$ semestre de 2010, p. 11

${ }^{271}$ MALBERG, Raymond Carré de. Contribution à la Theorie Générale de 1'État. Tomo I, Libreairie de la Socièté du Recueil Sirey, Paris, 1920, p.488.
} 
Já o Estado legal, continua o autor, ao contrário:

...é orientado numa outra direção: ele se prende a uma concepção política que tem relação com a organização fundamental dos poderes, concepção segundo a qual a autoridade administrativa deve, em todos os casos e em todas as matérias, ser subordinada ao órgão legislativo, no sentido de que ela não poderá agir senão em execução ou por permissão de uma lei.

Com relação ao tema, Eros Grau em sua obra "O Direito Posto e o Direito Pressuposto" ensina que:

O Estado autoritário, no entanto, inúmeras vezes se manifesta travestido de Estado de Direito. Sob a aparência de sujeição ao domínio da lei atua um Estado que lança mão da legalidade como instrumento de opressão e opróbrio. ${ }^{272}$

No Estado legalista, portanto, a lei se justifica por si mesmo, sendo legitimada tão somente pelo processo legislativo que a precede ${ }^{273}$. A ideologia do legalismo $^{274}$ é, portanto, negadora do direito, pois não leva em conta o cidadão ou os reais valores do direito, não havendo espaço para este tipo de pensamento no direito contemporâneo.

Um bom exemplo do modo de atuação legalista do Estado foi detectado por Luis Manoel Fonseca Pires ${ }^{275}$ naquilo que denominou de "vinculação negativa". Mesmo com os avanços do Estado liberal, persistia ainda um campo de atuação livre ao Estado, camuflada numa concepção distorcida da discricionariedade.

Entendia-se que, caso não houvesse lei regulando determinada matéria, haveria liberdade plena de atuação do Estado, ou seja, o Estado poderia fazer tudo o que a lei permitia e ainda o que ela não vedava. Tal noção de discricionariedade

${ }^{272}$ GRAU, Eros Roberto. O Direito Posto e o Direito Pressuposto. $7^{\circ}$.ed. São Paulo: Malheiros, 2008, p. 169.

${ }^{273}$ BARROS, Sérgio Resende de. Contribuição Dialética ao Constitucionalismo. Campinas; Millenniun Editora, 2008, p 140

${ }^{274}$ Nas palavras do professor Sérgio, na ob. cit.: "O legalismo é a exacerbação e a deturpação de uma valor liberal: a sujeição do Estado ao Direito"

${ }^{275}$ PIRES, Luis Manuel Fonseca, Limitações Administrativas à Liberdade e à Propriedade, Quartier Latin, São Paulo, 2006, pp. 144/146. 
sustentou-se por muito tempo, inclusive no Brasil, e justificou o abuso e o arbítrio no exercício do poder de polícia, contribuindo para a construção de uma visão enviesada sobre esta função pública.

Fato é que o "Estado de Direito Liberal", especialmente quando desvirtuado pelo legalismo, acabou tornando-se instrumento de dominação social, evidenciando a necessidade de novas e mais profundas transformações, dando ensejo ao surgimento de um novo fenômeno, o denominado Estado Social. ${ }^{276}$

\section{IV.4 - O Estado Social de Direito e o Poder de Polícia.}

Como vimos, o Estado liberal clássico perdurou até o início do século XX, sendo a Constituição alemã de Weimar de 1.919 apontada como o marco de um novo modelo, o da Social-Democracia. ${ }^{277}$

O forte individualismo, a inércia e a neutralidade do Estado liberal produziram grandes injustiças, o que provocou uma grande mobilização capitaneada por movimentos sociais que tinham como objetivo principal combater as desigualdades provocadas pela sociedade burguesa. Nasce o que se convencionou chamar de "consciência social". ${ }^{278}$

Na verdade, desde o final do século XIX, após muitas oscilações na forma de exercício do Poder, se percebia um movimento contra a soberania popular ilimitada, questão que marca e influência a elaboração das constituições desta época, como a da França de 1814. O grande marco destas novas mudanças, porém, é o surgimento nos Estados Unidos dos alicerces do controle de constitucionalidade, com o julgamento do famoso caso Marbury x Madison. ${ }^{279}$

Aponta-se ainda como um dos fatores que contribuíram para a ruína do modelo liberal de democracia o pouco interesse e empenho em estabelecer a ordem nas questões socioeconômicas, potencializando o individualismo materialista. Sahid

\footnotetext{
${ }^{276}$ PIRES, Luis Manuel Fonseca, Limitações Administrativas à Liberdade e à Propriedade, Quartier Latin, São Paulo, 2006, p. 148.

${ }^{277}$ MALUF, Sahid, Teoria Geral do Estado, $28^{\circ}$ ed., Saraiva, São Paulo, 2008, p. 315.

${ }^{278}$ SILVA, José Afonso da, Curso de Direito Constitucional Positivo, $22^{\mathrm{a}}$ ed., Malheiros Editores, São Paulo, 2003, p. 115.

${ }^{279}$ MENDES, Conrado Hübner, Controle de Constitucionalidade e Democracia, Campus Jurídico, Rio de Janeiro, 2008, p. 7
} 
Maluf retrata com aguda precisão o pensamento liberal e aponta com perfeição a forma como era exercido o poder de polícia nesta época:

Profundamente libertário e igualitário, declarou que todos os indivíduos possuem os mesmo direitos e as mesmas possibilidades, de sorte que ao Estado competia apenas policiar a ordem jurídica. A vida social e econômica deveria desenvolver-se naturalmente, à mercê das iniciativas individuais, de conformidade com as leis do liberalismo econômico, a lei da oferta e procura, a da livre concorrência, etc., as quais conduziriam a sociedade, fatalmente, a uma ordem ideal desejada por todos. Tinha o Estado por lema o postulado clássico do liberalismo econômico: Laissezfaire, laissez-passer, Et Le monde va la lui-même...

Essa atitude típica do Estado-polícia - L’État Gendarme -, atento somente à ordem jurídica e indiferente aos problemas sócio-ético-econômicos, acarretou o desequilíbrio social, a luta entre o capital e o trabalho e o desencadeamento dos atos de violência das massas proletárias, máxime, quando infladas pelo manifesto comunista. ${ }^{280}$

Neste ambiente de ebulições sociais e transformações rumo à socialdemocracia, o período pós II Guerra Mundial tem especial destaque, por marcar um expressivo avanço da justiça constitucional ${ }^{281}$. Tem especial protagonismo a Constituição de Bonn, de 1949 que inova ao dificultar o procedimento para edição de emendas à constituição e ao estabelecer um rol aberto de princípios, que não poderiam ser objeto de emendas $^{282}$.

Neste novo ambiente, o Estado é chamado a assumir uma nova condição: "a de agente do desenvolvimento e da justiça social. "283

Estava formado o cenário do que podemos denominar de "constitucionalismo clássico", pois ainda fortemente escorado na doutrina da separação de Poderes de Montesquieu. ${ }^{284}$

${ }^{280}$ MALUF, Sahid, Teoria Geral do Estado, $28^{\circ}$ ed., Saraiva, São Paulo, 2008, pp. 315 e 316.

${ }^{281}$ BARROSO, Luis Roberto - in www.oab.org.br/oabeditora, cit. pg. 2

${ }^{282}$ MENDES, Conrado Hübner, Controle de Constitucionalidade e Democracia, Campus Jurídico, Rio de Janeiro, 2008, p. 10.

${ }^{283}$ SUNDFELD, Carlos Ari, Fundamentos de Direito Público, $4^{a}$ ed., Malheiros Editores, São Paulo, 2009, p. 55.

${ }_{284}$ BARROS, Sérgio Resende de, Contribuição Dialética para o Constitucionalismo. Millenium, Campinas, SP , 2007, p. 36. 
Duas características marcam este "Estado Social": o maior zelo com o bem comum e o fortalecimento do Poder Executivo, que passa a agir em diversos flancos, visando implementar, agora de modo ativo, o interesse público.

Com base na teoria pura do direito de Hans Kelsen, o Estado Social caminhou no sentido de modificar o entendimento sobre o princípio da legalidade que passa a ser entendido em relação ao Estado como autorização para que este só faça o que a lei permite. É a denominada vinculação positiva. A discricionariedade passa ser exercida dentro dos parâmetros previsto em lei.

No entanto, mesmo estes avanços, garantidos constitucionalmente não foram capazes de gerar a confiança necessária. A própria expressão "social” causava grandes controvérsias, uma vez que cada corrente ideológica tinha uma visão particular do que julgava ser o direito social. ${ }^{285}$

Surge então a concepção de "Estado Social e Democrático de Direito" dando ênfase à participação dos indivíduos nos assuntos do Estado e na justiça social, como expressão dos princípios fundamentais. ${ }^{286}$

Mais uma vez o princípio da legalidade revigora-se, porém, conformado agora pela Constituição, com especial destaque para as garantias e aos direitos fundamentais dos indivíduos. $^{287}$

Conforme registrou Eros Grau em elucidativo parecer sobre o poder de polícia, induzido por tais mudanças, o Estado já não podia ser tomado como um sistema hermético, transformando-se de um "Estado de Direito-Formal" em um "Estado de Direito-Material":

...sustentado sobe a concreção do princípio democrático e de uma ordem jurídica legítima. ${ }^{288}$

\footnotetext{
${ }^{285}$ SILVA, José Afonso da, Curso de Direito Constitucional Positivo, $22^{\mathrm{a}}$ ed., Malheiros Editores, São Paulo, 2003, pp. 115/116.

${ }^{286}$ Muito embora o próprio professor José Afonso da Silva também critique esta designação por julgá-la de "tendência neocapitalista" e "delimitadora de qualquer passo a frente no sentido socialista". SILVA, José Afonso da, Curso de Direito Constitucional Positivo, 22 a ed., Malheiros Editores, São Paulo, 2003, p. 116.

${ }^{287}$ PIRES, Luis Manuel Fonseca, Limitações Administrativas à Liberdade e à Propriedade, Quartier Latin, São Paulo, 2006, pp. 149/152.

${ }^{288}$ GRAU, Eros Roberto, Poder de Polícia: Função Administrativa e Princípio da Legalidade: O Chamado "Direito Alternativo", Revista Trimestral de Direito Público, n 01/1993, Editora Malheiros, p. 92.
} 
Deste modo, o Estado Social Democrático ao mesmo tempo em que preserva os direitos da personalidade, impõe uma feição limitadora jurídicoconstitucional ao exercício destes direitos, bem como ao exercício do Poder Público. ${ }^{289}$

Neste movimento, ao transmudar-se o Estado estritamente liberal para um Estado intervencionista ${ }^{290}$, o exercício do poder de polícia acabou por extrapolar o campo da segurança e da ordem pública, para passar a regular também outros interesses coletivos tais como tais como os ligados as áreas sociais e econômica, característica deste novo modelo.

Nas palavras de Caio Tácito:

O poder de polícia do Estado, classicamente reservado à manutenção da ordem, da higiene e da tranquilidade públicas, se amplia de forma a abranger a regulação da atividade econômica; controle de preços; controle de produção e do comércio interno e exterior; controle do crédito e da moeda; controle do regime de bancos e de seguros; do mercado de capitais, etc. ${ }^{291}$

O poder de polícia, portanto, também se desenvolveu (avançou), deixando de estar limitado à segurança de aspirações liberais, para alcançar outros valores caros à sociedade moderna sociedade "pluriclasse", alargando o conceito de ordem pública que passou a abranger as relações de emprego, de produção de bens, de consumo, meio ambiente, patrimônio histórico, entre outros. Passou ainda a impor condutas positivas, tais como o uso produtivo das terras e o correto aproveitamento do solo urbano.

Deixou a atuação restrita de impor condutas negativas ou limitações à liberdade e propriedade, para alcançar uma dimensão muito mais abrangente. $^{292}$

No Estado Social e de Direito, o poder de polícia torna-se um verdadeiro "instrumento de defesa social em sentido amplo" ${ }^{293}$, expandindo não somente o seu alcance mas, principalmente a sua importância para a conquista e manutenção de uma sociedade mais equilibrada e justa.

${ }^{289}$ BONAVIDES, Paulo, Do Estado Liberal ao Estado Social, Malheiros Editores, 9a Ed., São Paulo, 2009, p. 204.

${ }^{290}$ MALUF, Sahid, Teoria Geral do Estado, $28^{\circ}$ ed., Saraiva, São Paulo, 2008, p. 316.

${ }^{291}$ TÁCITO, Caio, Temas de Direito Público (Estudos e Pareceres), Renovar, Rio de Janeiro, 1997, p. 379.

292 DI PIETRO, Maria Sylvia Zanella, Direito Administrativo, Atlas, 20ª ed., São Paulo , 2007, pp. $102 / 103$.

${ }^{293}$ TÁCITO, Caio, Temas de Direito Público (Estudos e Pareceres), Renovar, Rio de Janeiro, 1997, p. 523. 


\section{V - O PODER DE POLÍCIA NO ESTADO CONTEMPORÂNEO}

\section{V.1 - Estado Contemporâneo e Poder de Polícia}

O tema "poder de policia" está intrinsecamente relacionado com a constante tensão entre as liberdades e seus limites; entre o interesse individual e o interesse publico, razão pela qual, conforme demonstrado, as características do Estado e o momento histórico pelo qual atravessa influencia fortemente a manifestação deste poder. ${ }^{294}$

Como vimos, o exercício do poder de polícia variou na história de acordo com a característica do Estado, sendo certo que na medida em que a democracia foi se fortalecendo e os direitos individuais foram se consolidando, a polícia administrativa foi tomando os ares de uma função cogente, porém, controlada pela legalidade e mais modernamente pela legitimidade, conforme teremos oportunidade de expor a seguir.

Se, como afirma José Afonso da Silva: "a democracia que o Estado Democrático de Direito realiza há de ser um processo de convivência social numa sociedade livre, justa e solidária (art. $3^{\circ}$, I), em que o poder emana do povo, e deve ser exercido em proveito do povo... ${ }^{, 295}$, é certo que o poder de polícia apresenta-se como um dos mais importantes mecanismos para o atingimento deste desejado ambiente social, ao lado das demais políticas públicas e iniciativas de desenvolvimento humano, pois coloca-se justamente como instrumento moderador das condutas, visando impedir os abusos que o próprio exercício das liberdades muitas vezes acarreta.

Ao trabalhar a questão do poder de polícia, Ruy Cirne Lima, atento especificamente a tensão provocada pelo exercício das liberdades individuais e ao reflexo deste fenômeno na qualidade de vida da coletividade, demonstra de modo preciso que:

...na idéia de garantia de um direito, vai implícita a possibilidade de limitação desse direito ou do respectivo exercício. ${ }^{296}$

\footnotetext{
${ }^{294}$ MEDUAR, Odete, Direito Administrativo Moderno, $3^{\text {a }}$ ed., São Paulo, 1999, p. 364.

295 SILVA, José Afonso da, Curso de Direito Constitucional Positivo, 22a ed., Malheiros Editores, São Paulo, 2003, p. 119.

${ }^{296}$ CIRNE LIMA, Ruy, Princípios de Direito Administrativo, Malheiros Editores, 5a Ed., São Paulo, 1982, p. 105 .
} 
Coerente a esta premissa, Paulo Bonavides ${ }^{297}$, ao analisar o modelo de Estado Social, declara que é preciso buscar a "liberdade no Estado", uma vez que a liberdade contra o Estado "é ideia morta".

É neste cenário de busca pelo equilíbrio entre o exercício das liberdades e direitos individuais consagrados e a implementação de um necessário controle legitimado de tais manifestações por parte do Estado, é que passaremos a demonstrar como o poder de polícia se insere no contexto atual como instrumento de frenagem para contenção de abusos. ${ }^{298}$

A escolha inata feita pelo homem de viver em sociedade e de buscar neste convívio a sua realização, pressupõe uma luta permanente para que este ambiente social lhe seja favorável e satisfatório, de modo que possa nele se realizar plenamente como indivíduo. ${ }^{299}$

Neste ambiente, onde todos estão em busca de realizarem-se como indivíduos, sobressai a necessidade da implementação do equilíbrio entre seus interesses quando contrapostos, e entre os interesses destes e os do Estado - a chamada Justiça.

Kelsen desvenda de forma magistral esta intrincada teia ao afirmar que:

\begin{abstract}
A aspiração da justiça é - encarada psicologicamente - a eterna aspiração da felicidade, que o homem não pode encontrar sozinho e, para tanto, procura-a na sociedade. A felicidade social é denominada "justiça". ${ }^{300}$
\end{abstract}

Sem sombras de dúvidas, o homem contemporâneo fez opção pela vida nos grandes centros urbanos. Tal opção, cuja motivação não nos cabe aqui analisar, trouxe consigo a evidente potencialização da necessidade de ordenação das condutas, do exercício das liberdades e do uso da propriedade para que a almejada justiça fosse encontrada.

${ }^{297}$ BONAVIDES, Paulo, Do Estado Liberal ao Estado Social, Malheiros Editores, 9a Ed., São Paulo, 2009, p. 86.

${ }^{298}$ OSÓRIO, Fábio Medina, Direito Administrativo Sancionador, $3^{\mathrm{a}}$ ed., Editora Revista dos Tribunais, São Paulo, 2009, p. 95.

${ }^{299}$ MOREIRA NETO, Diogo de Figueiredo, Curso de Direito Administrativo, 15ª ed., Ed. Forense, 2009,

${ }_{300}^{\text {pp. }}$ KELSEN, Hans, Teoria Pura do Direito. $6^{a}$ ed., Tradução de José Cretella Jr. e Agnes Cretella, Editora Revista dos Tribunais, São Paulo, 2009, p. 78. 
A grande preocupação com a forma de ocupação urbana (urbanismo), por exemplo, demonstra quão premente é o desenvolvimento de novos instrumentos para implementação da segurança urbana. ${ }^{301}$

Conforme registrado por Paulo Márcio Cruz:

Na medida em que a Sociedade muda, se torna sedentária e se estratifica de um modo mais complexo, começa a aparecer um Poder político diferenciado, tanto cultural como estruturalmente, permanente $\mathrm{e}$ relativamente estável. Esta transição da Sociedade acéfala, ou tribal, ao Estado, passando pela cidade Estado, o império burocrático ou a sociedade feudal, faz, emergir um novo centro político que assume características funcionais e estruturais específicas. ${ }^{302}$

Com efeito, este ambiente social "pós-moderno", contemporâneo, traz a tona de modo enfático a questão do papel do Estado e, de modo especial, a função estatal de polícia, objeto de nosso estudo.

Fora do convívio social não há que se falar em poder de polícia. Ao contrário, como no âmbito do convívio social há sempre a probabilidade de conflitos, a função policial colocou-se como mecanismo de prevenção ou de resolução dos mesmos. É a iminência constante de conflitos, num ambiente de convívio necessário, que faz pressupor a necessidade de um mecanismo que possibilite o equilíbrio e a ordem. ${ }^{303}$

E aqui está uma das principais características do poder de polícia no Estado contemporâneo: na medida em que este convívio social se tornou mais intenso, a atividade de polícia do Estado foi se tornando mais necessária e, por consequência, cada vez mais invasiva e onipresente.

Ora, o interesse comum é gerado pela necessidade de vida em comum e esta intensa convivência pressupõe a imposição de um necessário equilíbrio, sob pena da instalação do caos. A polícia administrativa surge justamente para a implementação e defesa deste equilíbrio, tornando-se tão presente quanto necessária.

\footnotetext{
${ }^{301}$ QUEIROZ, Raphael Augusto Sofiati de, Direito Público \& Segurança Pública - Ensaios e Pareceres, Editora Lumen Juris, Rio de Janeiro, 2001, p. 41.

${ }^{302}$ CRUZ, Paulo Márcio, Política, Poder, Ideologia e Estado Contemporâneo, $2^{\text {a }}$ ed., Juruá, Curitiba, 2002, pp. $55 / 56$.

${ }^{03}$ FIORINI, Bartolome, Poder de Polícia, Editora Alfa, Buenos Aires, 1962, p. 14.
} 
O entendimento precário a cerca dos elementos componentes da função de polícia na vida hodierna (convivência social, perturbação e relação de equilíbrio) e a fluidez dos valores políticos são causas da confusão que existe sobre o tema.

Vale ponderar que esta mudança de entendimento sobre a incidência do poder de polícia já vêm ocorrendo há algum tempo. Hely Lopes Meirelles já afirmava que:

Os Estados Democráticos como o nosso inspiram-se nos princípios da liberdade e nos ideais de solidariedade humana. Daí o equilíbrio a ser procurado entre a fruição dos direitos de cada um e os interesses da coletividade, em favor do bem comum. ${ }^{304}$

Este almejado equilíbrio do sistema jurídico, num primeiro momento, é resguardado por um complexo sistema de leis que, ao mesmo tempo permitem a limitação do exercício dos direitos dos particulares em favor da Administração e ainda prevêem o arcabouço de garantias em favor dos particulares contra eventual abuso do Poder Público ${ }^{305}$.

Em razão desta mudança de paradigmas, o conceito de poder de polícia foi experimentando paulatinas mudanças em seu conceito.

Para Carlos Ari Sundfeld, que defende a idéia de um "Direito Administrativo Ordenador", a idéia de restringir direitos está inserida na idéia de poder de polícia que, porém, não se limita a este prisma. Segundo o autor:

...a atuação administrativa para limitar o direito à liberdade e à propriedade (ou, com mais precisão científica: de definir concretamente seus contornos é estudada dentro da noção de poder de polícia." ${ }^{306}$

Alexandre de Moraes ao abordar o tema, fala não só em restringir, mas também em condicionar direitos. Para ele:

\footnotetext{
${ }^{304}$ MEIRELLES, Hely Lopes, Direito Municipal Brasileiro, 12 a ed., Malheiros Editores, São Paulo, 2001, p. 444.

${ }^{305}$ MARQUES NETO, Floriano Peixoto de Azevedo, Regulação Estatal e Interesses Públicos, Malheiros, São Paulo, 2002, p. 98.

${ }^{306}$ SUNDFELD, Carlos Ari, Direito Administrativo Ordenador, Malheiros Editores, São Paulo, 2003, p. 10.
} 
Poder de policia é a faculdade concedida a Administração pública para restringir e condicionar o uso e gozo de bens, atividades e direitos individuais, em benefício da coletividade ou do próprio Estado, em busca da preservação da ordem pública e do estabelecimento de regras de conduta necessárias e suficientes para evitar conflitos e compatibilizar direitos. ${ }^{307}$

Juarez Freitas retrata a polícia administrativa como:

...qualquer restrição ou intervenção administrativa reguladora do exercício dos direitos fundamentais, colimando viabilizar, ordenadamente, o convívio de iniciativas, não raro antagônicas entre si, no resguardo das camadas-limites da sociedade. ${ }^{308}$

Sobressai na visão do autor a preocupação com a regulação e o ordenamento dos conflitos de interesses, o que corresponde a uma visão atualizada do exercício do poder de polícia.

\section{Para Marçal Justen Filho:}

O poder de polícia administrativa é a competência para disciplinar o exercício da autonomia privada para a realização de direitos fundamentais e da democracia, segundo os princípios da legalidade e da proporcionalidade. ${ }^{309}$

É justamente no bojo desta mudança de paradigma que o poder de polícia acabou por extrapolar uma de suas principais características clássicas, a saber, seu viés de contornos negativos.

A nova concepção de poder de polícia ultrapassa suas características de função negativa, apenas de limitação de direitos, apresentando-se contemporaneamente com fortes características positivas, no sentido de impor condutas,

${ }^{307}$ MORAES, Alexandre de, Direito Constitucional Administrativo, $4^{\mathrm{a}}$ ed., Atlas, São Paulo, 2007, p. 78. 308 FREITAS, Juarez, Poder de Polícia Administrativa - Novas reflexões, BDA/Boletim de Direito Administrativo 6/657-668, Ed. Nova Dimensão, São Paulo, Junho de 2006, p. 659.

${ }^{309}$ JUSTEN FILHO, Marçal, Curso de Direito Administrativo, $3^{\text {a }}$ edição, Saraiva, São Paulo, 2008, p. 459. 
disciplinando determinadas atividades, de modo que sejam resguardados interesses da coletividade e implementadas práticas socialmente desejáveis. ${ }^{310}$

Portanto, do conceito clássico de poder de polícia - limitado, repressor e focado em assegurar a ordem pública em sentido estrito - migrou-se agora para uma noção em que foi ampliado o âmbito da incidência da intervenção estatal, refletindo a aludida complexidade da sociedade moderna.

Caio Tácito registrou com grande perspicácia esta transformação:

A crise moderna do Estado se coloca na dimensão da passagem de um sistema de liberdade econômica, sujeita apenas às leis do mercado, para um regime de dirigismo sob o controle do poder regulamentar (rule making power) e do poder de planejar e socializar a economia (directing power). ${ }^{311}$

Vê-se que o poder de polícia extrapolou seus contornos de inspiração liberal (de simples atuação repressiva) para passar a exigir condutas positivas que fossem necessárias ao atingimento dos resultados sociais satisfatórios, passando a abranger áreas tais como o cultivo da terra e o aproveitamento do solo, o comércio de produtos e com especial destaque a proteção do meio ambiente. ${ }^{312}$

Juarez Freitas ${ }^{313}$, destacando as mudanças experimentadas pelo Estado contemporâneo conduz a constatar que os atuais valores sociais, muito mais complexos que outrora, impõem "um Estado mais dialógico do que monológico nas relações de administração”, exigindo um poder de polícia mais voltado a promoção do bem estar que a simples repressão. ${ }^{314}$

Tal característica é chamada por $\operatorname{Marçal}^{315}$ de "função promocional”, de onde decorreram as "sanções positivas ou premiais", através das quais,

\footnotetext{
${ }^{310}$ ARAÚJO, Edmir Netto de , Curso de Direito Administrativo, Saraiva, 5 a Ed., São Paulo, 2010, p. 1045.

311 TÁCITO, Caio, Poder de Polícia e Polícia do Poder, in: Direito Administrativo da Ordem Pública, (obr. Coletiva), $2^{a}$ ed., Editora Forense, Rio de Janeiro, 1987, p. 103.

312 DI PIETRO, Maria Sylvia Zanella, Poder de Polícia em Matéria Urbanística, in Temas de Direito Administrativo, Publicação conjunta, Ministério Público de São Paulo/Imprensa Oficial, São Paulo, 1999, p. 24.

${ }^{313}$ FREITAS, Juarez, Poder de Polícia Administrativa - Novas reflexões, BDA/Boletim de Direito Administrativo 6/657-668, Ed. Nova Dimensão, São Paulo, Junho de 2006, p. 667.

${ }^{314}$ No mesmo sentido: OLIVEIRA, Gustavo Henrique Justino de, Participação Administrativa, in Revista Eletrônica sobre a Reforma do Estado, n 03, setembro/novembro de 2005, Salvador, p. 26.

315 JUSTEN FILHO, Marçal, Curso de Direito Administrativo, $3^{\mathrm{a}}$ edição, Saraiva, São Paulo, 2008, p. 538.
} 
a norma prevê um benefício para o agente que cumprir determinado objetivo ou agir de acordo com determinado modelo de conduta.

Sob este prisma, cabe ênfase aos modernos mecanismos de implementação de práticas ecologicamente sustentáveis, através dos quais o Estado vem exigindo condutas que visem a assegurar um meio ambiente mais sadio e equilibrado, disciplinando a produção de bens, explicitando as condutas aceitáveis em ambientes coletivos (como a proibição de fumar em ambientes coletivos fechados) e interferindo nos modos de fruição da propriedade.

Um exemplo claro desta ampliação do campo de atuação do poder de polícia surge com a introdução constitucional da noção de função social da propriedade (artigos: 5º, inciso XXIII; 182; 184 e $185 \S$ único). De fato, a propriedade já não pode ser tida como o poder de dispor do bem de forma ilimitada. Muito pelo contrário, considera-se abusivo o uso quando é inadequado, excessivo, inútil ou provocador de lesão a direito juridicamente relevante e protegido, restando ao Estado, através do poder de polícia, o controle de sua adequada utilização. ${ }^{316}$

O poder de polícia evoluiu ainda no sentido de ultrapassar o âmbito da segurança política para passar a abranger a ordem social. Neste movimento, deixou de caracterizar-se por uma atuação meramente repressivo/preventivo passando a uma atuação também de cunho proativo, impondo condutas a fim de maximizar a boa convivência social. $^{317}$

Não se concebe mais a ideia restritiva de que a ordem pública se limita a segurança, tranquilidade e saúde. A ordem publica passou a ser encarada como o valor democrático da dignidade humana, que encontra no poder de polícia o instrumento de sua manutenção. ${ }^{318}$

Por certo, quando se examinam as limitações às liberdades contrapondo-se o Poder Público ao cidadão ou ao interesse de uma atividade econômica, por exemplo, constata-se a ocorrência de permanentes conflitos de princípios que necessitam ser enfrentados através de dispositivos há um tempo modernos e hábeis. É preciso ter em conta qual o conteúdo mínimo de liberdade subjetiva protegida pelo ordenamento, qual o limite máximo para o exercício das liberdades e quais são as posturas adequadas ao Estado e a seus órgãos e agentes para garantia do real interesse público.

\footnotetext{
${ }^{316}$ JUSTEN FILHO, Marçal, Curso de Direito Administrativo, $3^{\mathrm{a}}$ edição, Saraiva, São Paulo, 2008, p. 482. 317 ARAÚJO, Edmir Netto de, Curso de Direito Administrativo, Saraiva, 5a Ed., São Paulo, 2010, p. 1046.

${ }^{318}$ JUSTEN FILHO, Marçal, Curso de Direito Administrativo, $3^{\mathrm{a}}$ edição, Saraiva, São Paulo, 2008, p. 463.
} 
O mecanismo tradicional de enfrentamento destes conflitos de interesses foi retratado por Ruy Cirne Lime com a seguinte proposição:

A lei garante, nessa medida, os direitos individuais contra o próprio indivíduo; a Constituição garante-os contra o poder público. ${ }^{319}$

A resposta legal-positivista, porém, já não conseguia fazer frente ao dinamismo com que a sociedade evoluía, forçando o surgimento de novos meios de atuação do Poder Público com vistas a regular o convívio social.

Podemos apontar um bom exemplo do que ora expomos no percuciente no parecer de Floriano Azevedo Marques Neto sobre a aplicação de sanções por órgão regulador no setor elétrico, no qual ele chama a atenção para o fato de que, no caso, os meios de atuação para o exercício da autoridade não se coadunam com os mecanismos tradicionais de manifestação de poder. Segundo o autor, no caso examinado:

A unilateralidade e a exorbitância tradicionais no exercício da autoridade pública (poder extroverso) têm de dar lugar à interlocução, à mediação e à ponderação entre interesses divergentes, sem descurar do óbvio, da proteção da coletividade contra abusos dos agentes econômicos. ${ }^{320}$

Nota-se claramente no exemplo, a introdução dos elementos: "interlocução, mediação e ponderação" como exemplos de novas ferramentas aptas a proteção do indivíduo.

É para ocupar este espaço e aplicar o poder de polícia sob este novo enfoque que foram criadas as agências reguladoras, tais como a: ANVISA (vigilância sanitária), ANCINE (cinema), ANAC (aviação civil), ANATEL (telecomunicações), ANEEL (energia elétrica), ANP (comercialização de produtos derivados do petróleo) e até o Banco Central que atua como regulador do mercado financeiro, entre outros.

De outro lado, o Estado contemporâneo também evoluiu a sua visão em relação às garantias constitucionais de forma que, mesmo sendo reconhecidos como direitos fundamentais, de importância inquestionável, os direitos individuais não são tomados como absolutos e nem um fim em si mesmo. $\mathrm{O}$ exercício dos direitos individuais

${ }^{319}$ CIRNE LIMA, Ruy, Princípios de Direito Administrativo, Malheiros Editores, 5ª Ed., São Paulo, 1982, p. 105.

${ }^{320}$ MARQUeS NETO, Floriano de Azevedo, Aspectos Jurídicos do Exercício do Poder de Sanção por Órgão do Setor de Energia Elétrica, in Revista de Direito Administrativo, volume 221, Rio de Janeiro, renovar, 2000, p. 947. 
de modo desproporcional caracteriza-se como abuso de direito, militando contra a harmonia social. $^{321}$

Denota-se que neste novo contexto, a ordem pública e os interesses públicos estão sob a proteção do poder de polícia na medida em que são considerados juridicamente relevantes para a coletividade, em face do exercício do direito do particular.

A polícia administrativa no Estado contemporâneo deve buscar o estabelecimento da "convivência social mais harmoniosa possível", através de procedimentos que previnam ou diminuam os conflitos de interesses. ${ }^{322}$

No modelo clássico de Estado, as normas, para terem eficácia como instrumentos de polícia necessariamente vinham complementadas pela sanção ao seu descumprimento. No Estado contemporâneo, no modelo que denomina de "regulatório", o Estado, sem abrir mão desta prerrogativa (sanção), se utiliza de mecanismos positivos "promocionais" ou de técnicas de negociação a fim de incentivar a prática de condutas desejadas.

Tais peculiaridades deste novo modelo de atuação ganharam da doutrina a denominação de "soft-law", por não perderem o caráter normativo, mas, muitas vezes, se apresentarem sem a clássica "força jurídica vinculante". 323

É notória, portanto, a mudança de paradigma na utilização do poder de polícia no Estado contemporâneo, resgatando, sem prejuízo, as características positivas do instituto em sua concepção clássica. São oportunas nesse sentido as ainda atuais palavras de Cirne Lima quando afirma que:

À policia, ao revés, incumbe criar as condições gerais indispensáveis, para que os indivíduos, em ordem e harmonia, logrem conduzir, através do convívio quotidiano o desenvolvimento de suas relações sociais, independente de coação em cada caso concreto. ${ }^{324}$

Fato é que o desenvolvimento social nos últimos tempos acabaram por deslocar o centro do poder rumo à sociedade civil, obrigando o Estado a levar em conta de modo mais efetivo os interesses sociais realmente importantes. O processo de

\footnotetext{
${ }^{321}$ JUSTEN FILHO, Marçal, Curso de Direito Administrativo, $3^{\mathrm{a}}$ edição, Saraiva, São Paulo, 2008, p. 462.

${ }^{322}$ MEDUAR, Odete, Direito Administrativo Moderno, $3^{a}$ ed., São Paulo, 1999, p. 369/370.

323 JUSTEN FILHO, Marçal, Curso de Direito Administrativo, 3a edição, Saraiva, São Paulo, 2008, p. 539.

${ }^{324}$ CIRNE LIMA, Ruy, Princípios de Direito Administrativo, Malheiros Editores, 5a Ed., São Paulo, 1982, p. 106.
} 
institucionalização da sociedade obrigou o Estado a cada vez mais levar em conta a legitimação como condição para a prática de atos de autoridade ${ }^{325}$.

Nas palavras de Caio Tácito:

Em cada uma dessas fases, em que se aperfeiçoa a busca da fidelidade ao princípio democrático, o poder de polícia é um meio indispensável de ação dos governantes na prática do dever de boa administração. ${ }^{326}$

\section{V.2 - O Princípio da Soberania Popular e o Poder de Polícia.}

Não se pode conceber hodiernamente a ideia de uma verdadeira democracia desvinculada da noção de que é o povo quem efetivamente governa.

Conforme ensina Friedrich Müller:

O termo "democracia" não deriva apenas etimologicamente de "povo". Estados democráticos chamam-se governos "do povo" "Volks" herrschaften]; eles se justificam afirmando que em última instância o povo estaria "governando" herrsascht.$^{327}$

Com efeito, num verdadeiro Estado Democrático e de Direito, não há que se colocar em dúvida qual é a origem do poder e como ele deve ser exercido.

Na indelével lição de Paulo Bonavides:

O princípio da soberania popular compreendia as regras básicas de governo e de organização estrutural do ordenamento jurídico, sendo, ao mesmo passo, fonte de todo o poder que legitima a autoridade e se exerce nos limites consensuais do contrato social. Encarna o princípio do governo democrático e soberano, cujo sujeito e destinatário na concretude do sistema é o cidadão.

${ }^{325}$ MARQUES NETO, Floriano Peixoto de Azevedo, Regulação Estatal e Interesses Públicos, Malheiros, São Paulo, 2002, pp. 31/32.

${ }^{326}$ TÁCITO, Caio, Poder de Polícia e Polícia do Poder, in: Direito Administrativo da Ordem Pública, (obr. Coletiva), $2^{a}$ ed., Editora Forense, Rio de Janeiro, 1987, p. 103.

327 MÜLLER, Friedrich, Quem é o Povo? A Questão Fundamental da Democracia, Ed. Revista dos Tribunais, $4^{\text {a }}$ ed., São Paulo, 2009, p. 39. 
Em suma, o princípio da soberania popular é a carta de navegação da cidadania rumo às conquistas democráticas, tanto para esta como para as futuras gerações. $" 328$

Habermas $^{329}$ afirma com a contundência que lhe é peculiar que os direitos humanos e o princípio da soberania do povo "formam as ideias em cuja luz ainda é possivel justificar o direito moderno."

É com este norte que aprofundaremos o nosso estudo.

Como vimos, ao impor limitações, ou seja, ao exercer o poder de polícia, a Administração deve levar em conta não só a esfera privativa da vida pessoal, mas principalmente o fato de que o cidadão é sujeito e não objeto da coisa pública, pois contribui com a formação da vontade política. Em outras palavras, a atuação estatal contemporânea deve voltar-se a garantia da existência e desenvolvimento do próprio cidadão, razão última do Estado.

Não se pode olvidar que, em última instância, "todo o poder emana do povo" e o poder exercido pela Administração nada mais deve ser do que o exercício reflexivo deste poder. ${ }^{330}$

É necessário trazer claro na mente que o Estado democrático encontra o fundamento para o exercício do poder - e até mesmo para o uso da força (coerção) - justamente na vontade soberana do povo. ${ }^{331}$

Desde o estabelecimento da propriedade privada dos meios de produção, surgiu a necessidade do exercício de um poder que evite o conflito de classes. Tal poder, para se manter hígido num ambiente democrático precisa ser exercido por autoridade legitimada sob pena de não conseguir manter íntegro o sistema. ${ }^{332}$

É justamente por esta razão que o Estado contemporâneo não tolera o exercício de um poder limitador que não seja reflexo e resposta às necessidades dos cidadãos, num ambiente de convívio harmônico e salutar. Neste ambiente só é poder

\footnotetext{
${ }^{328}$ BONAVIDES, Paulo, Teoria Constitucional da Democracia Participativa, Malheiros Editores, $3^{\text {a }}$ ed., São Paulo, 2008, pp. 10/11.

${ }^{329}$ HABERMAS, Jürgen, Direito e Democracia - entre a facticidade e validade - vol. I, Biblioteca Tempo Brasileiro, Rio de Janeiro, 2.010, p. 133.

${ }^{330}$ FIGUEIREDO, Lúcia Valle, Curso de Direito Administrativo, $9^{\mathrm{a}}$ edição, Malheiros, São Paulo, 2008, p. 283.

${ }^{331}$ MÜLLER, Friedrich, Quem é o Povo? A Questão Fundamental da Democracia, Ed. Revista dos Tribunais, $4^{\text {a }}$ ed., São Paulo, 2009, p. 39.

${ }^{332}$ HABERMAS, Jürgen, A Crise de Legitimidade no Capitalismo Tardio, Edições Tempo Brasileiro, Rio de Janeiro, 1999, p. 26.
} 
de polícia aquele que emana e se manifesta de forma legal e legítima. Fora disto não se trata de poder de polícia e sim de uso arbitrário da força.

Com efeito, o "Estado Democrático de Direito" pressupõe tanto um estado de legalidade quanto um estado de legitimidade, que vem estampado no adjetivo “democrático" da expressão grafada no artigo $1^{\circ}$ da Constituição Federal de 1.988.

Vigora, pois, a noção de um "Estado de serviço" em que o poder político deve é exercido com a finalidade de servir de instrumento para a realização e proteção dos direitos fundamentais. O poder de polícia está justamente inserido nas funções deste "Estado de serviço prestador" que é colocado primariamente em relação ao "Estado propulsor”, que desenvolve além das atividades clássicas de polícia, as funções de fomento das mais variadas áreas da atividade social e econômica. ${ }^{333}$

O Estado evoluiu, portanto, de uma situação em que o poder era expresso de modo impositivo, para outra, em que o poder se manifesta de modo propositivo, na forma de uma função a serviço do interesse público. A atividade de polícia do Estado passa a ser exercida de modo a promover a ordenação das atividades privadas ou, como expressaram Enterría e Fernándes:

"Administración prestacional, que realiza servícios o prestaciones en favor de los administrados.". 334

As ações administrativas de polícia passaram, portanto, a ser exercidas tendo como limite óbvio os direitos fundamentais consagrados constitucionalmente e, como fundamento, a vontade popular soberana. Fora disso - é preciso frisar - não há que se falar modernamente em poder de polícia.

Isto porque se passou a respeitar o fato de que os valores nascem na sociedade e, portanto, é a sociedade que deve impor os limites ao exercício da polícia administrativa. Por isto, torna-se imprescindível a criação das condições para que a expressão da vontade que emana do povo se apresente legitimando o poder, especialmente o poder de polícia, na medida em que se volta justamente a limitar a liberdade e os direitos dos verdadeiros detentores do poder.

${ }^{333}$ MOREIRA NETO, Diogo de Figueiredo, Quatro Paradigmas do Direito Administrativo Pós-Moderno, Ed. Forense, Rio de Janeiro, 2008, p. 43.

334 ENTERRÍA, Eduardo Garcia de, e FERNANDÉz, Thomás-Ramón. Curso de Derecho Administrativo, $4^{\text {a }}$ Ed., Vol. II, Civitas, Madri, 1997, p. 107. 
Diante deste panorama, resta evidente que com os novos rumos da democratização, o Estado-Governo perde sua condição de personagem principal no campo das definições de políticas de convivência, ganhando força a atuação da sociedade no que se refere ao exercício de poder. Este cenário força uma postura diferente do Poder Público que passa a ter que argumentar com a sociedade de forma racional e objetiva. ${ }^{335}$

Nas palavras de Bonavides:

Nisto consiste a essência e o espírito da nova legitimidade: o ábaco com a Constituição aberta, onde, sem a cidadania não se governa e sem o povo não se alcança a soberania legítima. ${ }^{336}$

\section{V.3 - A Participação Popular como Fator de Legitimação ao Exercício do Poder de Polícia.}

Ao contrário do que se possa imaginar, a ideia da participação popular legitimadora das deliberações a respeito do exercício do poder de polícia na comunidade local remete ao período em que o Estado de Direito ainda vicejava. ${ }^{337}$

Há notícia de que surgiram em muitos burgos ou municípios de meados do século XVIII, conselhos diretivos que, através dos representantes de cada grupo (agremiações) e da nascente burguesia, dispunham sobre as necessidades comuns e atuava, inclusive em assuntos ligados à moral, a segurança e as atividades desenvolvidas pelas agremiações.

Muito embora de modo rudimentar, já na época desenvolvia-se uma espécie de polícia de vizinhos que fazia as vezes de uma atividade policial desenvolvida pelo Estado. Tal atividade policial, exercida nas cidades pelos locais, era um desdobramento da atividade policial do príncipe e se preocupava em especial com assuntos

\footnotetext{
${ }^{335}$ MOREIRA NETO, Diogo de Figueiredo, Quatro Paradigmas do Direito Administrativo Pós-Moderno, Ed. Forense, Rio de Janeiro, 2008, p. 76.

${ }^{336}$ BONAVIDES, Paulo, Teoria Constitucional da Democracia Participativa, Malheiros Editores, $3^{\mathrm{a}}$ ed., São Paulo, 2008, p. 36.

${ }^{337}$ Segundo BONAVIDES, Paulo, Teoria Constitucional da Democracia Participativa, Malheiros Editores, 3 ed., São Paulo, 2008: “ o que ocorre, alias, em âmbito comunitário e se comprova, por igual, na tradição secular dos primitivos municípios hispânicos: e se retrogradarmos até os primórdios da civilização política do ocidente, também a mesma verdade se nos depara nos modelos tradicionais e clássicos da civitas e da polis grega."
} 
do cotidiano, como a manutenção das ruas, com a ação dos delinquentes locais, a segurança e a tranquilidade entre os vizinhos, ou seja, tinha a ver com o dia a dia local. ${ }^{338}$

Hodiernamente a participação popular, característica inerente à cidadania representa (neste aspecto, assim como na polis grega ou na república romana) o compromisso do indivíduo com a coletividade; representa o seu envolvimento com o todo e seus deveres para com o outro. Remete a uma ideia de deveres e não somente a de direitos.

Isto porque, é a participação democrática, que Paulo Bonavides 339 denomina de "repolitização da legitimidade", que marca a transição entre as democracias meramente representativas e a democracia participativa, que exige do Estado uma maior atenção aos movimentos sociais e uma atuação gerencial e jurídica mais acurada.

Floriano de Azevedo Marques ${ }^{340}$ chama de "republicização" o processo pelo qual o Estado vai adotando um perfil mais funcional, orientado pelo interesse público, e submetido tanto a um controle político como a procedimentos de deliberação e avaliação levados a efeito pela sociedade.

Esta visão de um Estado funcional, ou seja, que trabalha no sentido de desempenhar funções específicas coaduna-se perfeitamente com as lições deixadas por Jorge Miranda para quem são exatamente as funções do Estado que expõem o envolvimento entre o Poder Público e a sociedade, produzindo os primeiros passos rumos ao exercício legitimado do poder. Para ele:

A crescente complexidade das funções assumidas pelo Estado - da garantia da segurança perante o exterior e da paz civil à promoção do bem-estar e da justiça social - decorre do alargamento das necessidades humanas, das pretensões de intervenção dos governantes e dos meios de que se podem dotar; mas é também uma maneira de o Estado ou os governantes em concreto justificarem sua permanência no poder. ${ }^{341}$

Cumpre neste momento ponderar que a democracia participativa pressupõe um Estado que gradualmente dê preferência às ações fundadas no debate e nas

\footnotetext{
${ }^{338}$ FIORINI, Bartolome, Poder de Polícia, Editora Alfa, Buenos Aires, 1962, pp. 41/43.

${ }^{339}$ BONAVIDES, Paulo, Teoria Constitucional da Democracia Participativa, Malheiros Editores, $3^{\text {a }}$ ed., São Paulo, 2008, p. 10.

${ }^{340}$ MARQUES NETO, Floriano Peixoto de Azevedo, Regulação Estatal e Interesses Públicos, Malheiros, São Paulo, 2002, p. 148.

${ }^{341}$ MIRANDA, Jorge, Funções, Órgãos e Atos do Estado, Universidade de Lisboa, 1990, pp. $3 / 5$.
} 
negociações dos assuntos ligados à sociedade, incorporando à noção de interesse público, um conteúdo cada vez mais próximo da realidade e cada vez mais afastado de seu (Estado) próprio interesse.

A democracia tradicional, exclusivamente representativa, cede espaço por se mostrar incapaz de atender aos anseios de legitimação das políticas públicas, fundamentadas na ampliação da participação popular. ${ }^{342}$

Nesta perspectiva ganham importância os "espaços públicos" como verdadeiros "pólos políticos de conscientização participativa da cidadania", em detrimento do radical formalismo tradicional. ${ }^{343}$

Tal dinâmica torna-se muito mais relevante na medida em que as normas a serem trabalhadas são as denominadas "normas de ação", que segundo Habermas, devem ser oriundas de um procedimento em que todos os atingidos por elas devem ter o poder de dar o seu assentimento através de uma dialógica racional.

Vale transcrever o entendimento do autor:

Eu entendo por "normas de ação" expectativas de comportamento generalizadas temporal, social e objetivamente. Para mim, "atingido" é todo aquele cujos interesses serão afetados pelas prováveis consequiências provocadas pela regulamentação de uma prática geral através de normas. E "discurso racional" é toda a tentativa de entendimento sobre pretensões de validade problemática, na medida em que ele se realiza sob condições de informação que permitem o movimento livre de temas e contribuições, informações e argumentos no interior de um espaço público constituído através de obrigações ilocucionárias. $^{344}$

Tudo enfim, deve apontar para uma modificação substancial na maneira de legislar, de administrar e de resolver conflitos e, em especial, uma mudança significativa na forma de desempenhar a função de polícia, tipicamente oriunda de uma

\footnotetext{
${ }^{342}$ MOREIRA NETO, Diogo de Figueiredo, Curso de Direito Administrativo, $15^{\mathrm{a}}$ ed., Ed. Forense, 2009, p. 86.

343 BONAVIDES, Paulo, Teoria Constitucional da Democracia Participativa, Malheiros Editores, $3^{\text {a }}$ ed., São Paulo, 2008, p. 279.

${ }^{344}$ HABERMAS, Jürgen, Direito e Democracia - entre a facticidade e validade - vol I, Biblioteca Tempo Brasileiro, Rio de Janeiro, 2.010, p. 142.
} 
"norma de ação", que deve passar a ser exercida na forma que realmente atenda aos anseios de segurança da coletividade atingida pela medida concreta. ${ }^{345}$

Conforme já indicava Montoro:

Esses diferentes processos exigem e promovem a tomada de consciência dos verdadeiros problemas da comunidade e de seus membros, o exame das conseqüências e implicações das medidas propostas ou adotadas, a discussão da viabilidade dos diversos meios, etc. ${ }^{346}$

O ambiente participativo, portanto, ao envolver o indivíduo no processo decisório, alça o cidadão ao nível de protagonista das decisões mais relevantes ao seu ambiente, sobrelevando o valor desta dinâmica nos casos em que as decisões digam respeito à sua liberdade, ao seu patrimônio ou a utilização dos recursos naturais, etc.

Nas palavras de Gustavo Henrique Justino de Oliveira:

De uma perspectiva unidimensional Estado-súdito (o indivíduo não era possuidor de direitos frente ao Estado, mas unicamente de deveres para com o Estado), passou-se a uma perspectiva bidimensional Estadocidadão (direitos e deveres originados do vínculo da cidadania destinamse tanto ao Estado quanto aos indivíduos). ${ }^{347}$

É diante deste contexto que o poder de polícia nos dias atuais deve ser desempenhado preferencialmente através de métodos que premiem o diálogo e a persuasão, que são justamente os mecanismos de formação da vontade popular, restando num segundo plano, caso inevitável, a sanção de caráter negativo. ${ }^{348}$

No Estado contemporâneo, a cidadania se realiza através das características do denominado "conteúdo social” que visa atingir, uma vez que mesmo questões ligadas a individualidade podem ser alcançadas através da manifestação concreta do Estado, como o que ocorre na questão da segurança ou do bem estar dos cidadãos.

\footnotetext{
${ }^{345}$ MOREIRA NETO, Diogo de Figueiredo, Quatro Paradigmas do Direito Administrativo Pós-Moderno, Ed. Forense, Rio de Janeiro, 2008, pp. 114/116.

${ }^{346}$ MONTORO, Franco, Da Democracia que Temos para a Democracia que Queremos, Ed. Paz e Terra, Rio de Janeiro, 1974, p. 45.

347 OLIVEIRA, Gustavo Henrique Justino de, Participação Administrativa, in Revista Eletrônica sobre a Reforma do Estado, nº 03, Salvador, setembro/novembro de 2005, p. 08.

348 FREITAS, Juarez, Poder de Polícia Administrativa - Novas Reflexões, BDA/Boletim de Direito Administrativo 6/657-668, Ed. Nova Dimensão, São Paulo, Junho de 2006, p. 659.
} 
Só há democracia de fato quando a vontade manifesta do Estado foi formada por meio da vontade do cidadão ${ }^{349}$. É por isto que só há exercício legítimo do poder de polícia quando este represente uma resposta às deliberações coletivas, tomadas em um ambiente em que os interesses que sofrerão sua interferência estiverem devidamente representados. A representação dos indivíduos afetados na tomada de decisões é que as qualifica uma ação como democrática ${ }^{350}$, inclusive as de polícia.

É a transparência e a previsibilidade no procedimento de tomada de decisões que garante que o direito dos indivíduos será preservado ${ }^{351}$, especialmente no que diz respeito ao exercício do poder de polícia, por natureza invasivo.

Esta "legitimidade racional moderna" tende a resolver a questão da justificação das normas e princípios que devem regular o convívio social contemporâneo, na medida em que é tida como legítima a norma ou ação em que os cidadãos reconhecem o uso público da razão. Deste modo é que se deve procurar estabelecer as normas, em especial as que digam respeito ao poder de polícia e seu exercício pela Administração.

Eros Grau ensina que:

...podemos afirmar que a norma jurídica é legítima - dotada de legitimidade - quando existir correspondência entre o comando nela consubstanciado e o sentido admitido e consentido pelo todo social, a partir da realidade coletada como justificadora do preceito normatizado. A legitimidade é um conceito material ao passo que a legalidade é um conceito formal. ${ }^{352}$

A legitimidade, que reside na razão publica traduzida pelo reconhecimento pelo cidadão autônomo, de que determinadas leis ou atos de polícia possuem um conteúdo aceitável pela maioria, por estar em consonância com o senso comum, é que faz com que tais medidas sejam tidas como justas.

\footnotetext{
${ }^{349}$ BONA VIDES, Paulo, Teoria Constitucional da Democracia Participativa, Malheiros Editores, $3^{\mathrm{a}}$ ed., São Paulo, 2008, p. 57.

350 REIS, Fábio Wanderley, in: Deliberação, Interesses e Sociedade Civil, texto integrante da obra: Participação e Deliberação - Teoria Democrática e Experiências Institucionais no Brasil Contemporâneo, COELHO, Vera Schattan P., e NOBRE, Marcos (org.), Editora 34, São Paulo, 2004, pp. 66/75.

351 MOREIRA NETO, Diogo de Figueiredo, Novas Tendências da Democracia: Consenso e Direito Público na Virada do Século - O Caso Brasileiro, in Revista Eletrônica sobre a Reforma do Estado, $\mathrm{n}^{\circ}$ 13, março/abril/maio de 2008, Salvador, p. 02.

${ }^{352}$ GRAU, Eros Roberto, O Direito Posto e o Direito Pressuposto, $7^{\mathrm{a}}$ ed., Malheiros, São Paulo, 2008, p. 86.
} 
Nas palavras de Bonavides:

Legitimidade que mana, enfim, do cidadão erguido faticamente às últimas instâncias do poder, tendo de sua mão, por expressão de soberania, os freios à conduta e à política dos governos, que dele, o cidadão mesmo, como povo, há de traçar, sancionar e executar. ${ }^{353}$

O poder de polícia, exercido nestes moldes é, na verdade, a expressão de um poder de coerção autorizado e legitimado em toda sua existência e extensão, indo, portanto, além do entendimento contido no modelo do contrato social de Hobbes, em que o consentimento restringia-se ao momento do reconhecimento da autoridade. $^{354}$

A norma ou a ação emanada da cooperação dos integrantes do convívio social tem a virtude de ir além, dirigindo a expressão das diversas formas de poder rumo aos fins almejados, promovendo o desenvolvimento e a segurança sem abrir mão da confiabilidade indispensável à subsistência do Estado. ${ }^{355}$

É, pois, o uso público da razão que confere validade ao conteúdo normativo e ao exercício do poder de polícia, produzindo sua aceitação. Num ambiente democrático-participativo as normas e atos de polícia se tornam legítimos na medida em que os cidadãos atingidos por ela podem, através do uso da razão na esfera pública, compreender o propósito destas em suas vidas.

Vale aqui a advertência de que não se sustenta a tentativa de se substituir a legitimidade pela legalidade. ${ }^{356} \mathrm{Na}$ verdade, neste sentido são diametralmente opostos os dois conceitos, não se sustentando nem mesmo a ideia de uma legitimidade derivada exclusivamente da legalidade (legalismo/formalismo). ${ }^{357}$

Para alcançar tal nível de efetividade, a democracia contemporânea deve apoiar-se por um lado nos mecanismos públicos de deliberação, tais como os processos eleitorais, assembléias legislativas, partidos políticos, audiências públicas,

\footnotetext{
${ }^{353}$ BONA VIDES, Paulo, Teoria Constitucional da Democracia Participativa, Malheiros Editores, $3^{\mathrm{a}}$ ed., São Paulo, 2008, p. 19.

${ }^{354}$ WERLE, Denílson L, e SOARES, Mauro V., in: Direito e Democracia - Um Guia de Leitura de Habermas, NOBRE, Marcos e TERRA, Ricardo (organizadores), Ed. Malheiros, São Paulo, 2008, pp. $123 / 125$.

${ }^{355}$ MOREIRA NETO, Diogo de Figueiredo, Novas Tendências da Democracia: Consenso e Direito Público na Virada do Século - O Caso Brasileiro, in Revista Eletrônica sobre a Reforma do Estado, $n^{\circ} 13$, março/abril/maio de 2008, Salvador, p. 03.

${ }_{356}$ GRAU, Eros Roberto, O Direito Posto e o Direito Pressuposto, $7^{\mathrm{a}}$ ed., Malheiros, São Paulo, 2008, p. 84.

${ }^{357}$ SCHIMITT, Carl, Legalidade e Legitimidade, Ed. Del Rey, Belo Horizonte, 2007, pp. 08/09.
} 
conselhos municipais e estaduais com participação paritária de órgãos representativos dos cidadãos, etc., e de outro lado, na sociedade organizada e mobilizada culturalmente.

O Estado contemporâneo impõe uma visão funcionalista do Direito Administrativo no qual os resultados de suas ações devem ser qualificados por sua legitimidade e eficiência, num contexto onde sejam levadas em consideração tanto a atuação das "micro-organizações político-administrativas" tais como: o município, os conselhos, etc., e também as "macro-organizações político-administrativas", abrangendo desde os interesses nacionais até os metanacionais, tais como os dos blocos econômicos. ${ }^{358}$

Este exercício do direito de participação, que é expressão da soberania do povo, remete "à institucionalização jurídica de uma formação pública de opinião e da vontade, a qual culmina em resoluções sobre leis e política. "359. Em outras palavras, no Estado contemporâneo, a própria participação, expressão da soberania popular, promove e força a criação de um ambiente jurídico em que as decisões relevantes são formadas de modo a traduzir as aspirações dos indivíduos.

Não se concebe mais o uso arbitrário e impositivo da autoridade, pois o Poder Público não tem mais a hegemonia do interesse público, que passou a ser determinado de fato pela coletividade ${ }^{360}$.

Nas palavras de Moreira Neto:

...a face imperativa do poder só deve aparecer quando absolutamente necessário e no que for absolutamente indispensável. ${ }^{361}$

É através destas espécies de mecanismos que o princípio de que "todo poder emana do povo" se torna real, ou seja, através de sistemas que tornem efetivas e respeitadas a opinião e a vontade dos cidadãos. ${ }^{362}$

\footnotetext{
${ }^{358}$ MOREIRA NETO, Diogo de Figueiredo, Quatro Paradigmas do Direito Administrativo Pós-Moderno, Ed. Forense, Rio de Janeiro, 2008, p. 105.

${ }^{359}$ HABERMAS, Jürgen, Direito e Democracia - entre a facticidade e validade - vol. I, Biblioteca Tempo Brasileiro, Rio de Janeiro, 2.010, p. 190.

${ }^{360}$ MARQUES NETO, Floriano Peixoto de Azevedo, Regulação Estatal e Interesses Públicos, Malheiros, São Paulo, 2002, p. 157.

361 MOREIRA NETO, Diogo de Figueiredo, Novas Tendências da Democracia: Consenso e Direito Público na Virada do Século - O Caso Brasileiro, in Revista Eletrônica sobre a Reforma do Estado, $\mathrm{n}^{\circ}$ 13, março/abril/maio de 2008, Salvador, p. 18.

362 WERLE, Denílson Luiz, in: Democracia Deliberativa e os Limites da Razão Pública. texto integrante da obra: Participação e Deliberação - Teoria Democrática e Experiências Institucionais no Brasil Contemporâneo, COELHO, Vera Schattan P., e NOBRE, Marcos (org.), Editora 34, São Paulo, 2004, pp. $140 / 150$.
} 
O modelo ideal, portanto, é aquele em que as pessoas afetadas pelo exercício do poder de polícia testem a sua validade e que, através deste teste de pretensão e extensão, possam chegar à convicção de que as normas nas quais estão fundamentados os atos de polícia estão de acordo com a vontade legitimante. Neste modelo há um convencimento racional da validade da norma e do exercício de poder dela decorrente. ${ }^{363}$

Isto porque, de todos os avanços alcançados pelo Estado contemporâneo, é a legitimidade da ação administrativa certamente um de seus maiores estandartes, uma vez que por meio desta ótica, ele (Estado) se vê impelido a agir com vistas ao cumprimento da finalidade verdadeiramente pública e de modo eficiente, num ambiente em que o resultado da prestação do serviço público (entre os quais o exercício do poder de polícia, como vimos), é reflexo da aspiração social que o legitimou, tendendo a ser altamente satisfatório. ${ }^{364}$

Com efeito, não sendo legítimo, todo ato do Estado (em especial o de polícia, por sua natureza invasiva) tende a ser injusto e violador dos direitos garantidos constitucionalmente. ${ }^{365}$

Vale frisar, é neste sentido que a participação popular, exercida do modo mais participativo possível, dá nova conformação ao exercício do poder de polícia. Através da participação, especialmente da comunidade diretamente atingida pelo ato de polícia, é que se experimenta a atuação de um Estado funcional, que atua imbuído de um poder legítimo e, portanto, aceitável pelos cidadãos.

Neste ambiente, a legitimidade do exercício do poder (legitimidade do direito) advém de uma autoridade que é produzida pela somatória dos comandos que emanam dos detentores do poder e da deliberação do grupo social. Deste modo, insistimos, o direito não basta para fundamentar a autoridade, não sendo capaz por si só de produzir normas jurídicas legítimas. ${ }^{366}$

A participação popular na conformação do poder de polícia possibilita ainda que as realidades locais e regionais sejam levadas em conta, tanto no momento da elaboração das leis restritivas da liberdade e/ou da propriedade, quanto no momento do efetivo exercício dos atos de polícia delas decorrentes.

\footnotetext{
${ }^{363}$ HABERMAS, Jürgen, A Crise de Legitimidade no Capitalismo Tardio, Edições Tempo Brasileiro, Rio de Janeiro, 1999, p. 133.

${ }^{364}$ MOREIRA NETO, Diogo de Figueiredo, Quatro Paradigmas do Direito Administrativo Pós-Moderno, Ed. Forense, Rio de Janeiro, 2008, p. 29.

${ }^{365}$ BONAVIDES, Paulo, Teoria Constitucional da Democracia Participativa, Malheiros Editores, $3^{a}$ ed., São Paulo, 2008, p. 39.

${ }^{366}$ GRAU, Eros Roberto, O Direito Posto e o Direito Pressuposto, $7^{\mathrm{a}}$ ed., Malheiros, São Paulo, 2008 , p. 87.
} 
Esta nova forma de exercício do poder de polícia é que assegura a "calibragem entre direitos e sujeições" e permite a Autoridade pública agir de modo legitimado. ${ }^{367}$

Tal cenário é extremamente desejável, especialmente na medida em que se constata que o que é tolerável ou aceitável em determinada localidade ou mesmo em determinado bairro, pode não ser suportável em outro, em razão de suas características urbanísticas, históricas, culturais, etc.

Neste sentido, a presença de ambulantes em determinadas áreas pode ser extremamente benéfica a economia de determinada região de uma grande cidade e absolutamente nociva em outra. A possibilidade da participação popular na conformação da regulamentação destas questões trará legitimidade para a atuação Estatal na medida em que a própria comunidade identificará seus anseios e propostas na atuação Administrativa, apoiando-as.

Mas para que este nível de participação possa se tornar realizável é preciso, reafirme-se, garantir que o cidadão tenha condições materiais mínimas para o exercício de uma atividade política democrática ${ }^{368}$. É preciso estabelecer um ambiente em que o cidadão possa exercitar a autonomia política ao mesmo tempo em que cumpre seu dever cívico de participar das decisões de sua comunidade.

É necessário o desenvolvimento de ações de combate as desigualdades materiais para que se tornem efetivos os direitos de cidadania. Tais mecanismos são expressos através dos denominados direitos sociais. Vale lembrar, os direitos políticos vieram em complemento ao direito civil e os direitos sociais em complemento àqueles, compensando as desigualdades materiais que impediam o exercício efetivo da igualdade formal que o direito já apregoava. ${ }^{369}$

É certo que o exercício da democracia não se sustenta tão somente através da garantia formal de direitos. É preciso que tais garantias tenham respaldo em uma cultura política democrática pragmática.

\footnotetext{
${ }^{367}$ MARQUES NETO, Floriano Peixoto de Azevedo, Regulação Estatal e Interesses Públicos, Malheiros, São Paulo, 2002, p. 98.

${ }^{368}$ Neste sentido, Pedro Salazar Ugarte consigna que: "Uma verdadeira teoria da democracia deve sublinhar a importância da participação cidadã no maior número de espaços de decisão possíveis. UGARTE, Pedro Salazer, in: Que participação, para qual democracia?; texto integrante da obra: Participação e Deliberação Teoria Democrática e Experiências Institucionais no Brasil Contemporâneo, COELHO, Vera Schattan P., e NOBRE, Marcos (org.), Editora 34, São Paulo, 2004, p.102.

369 NOBRE, Marcos, in Participação e Deliberação na Teoria Democrática - Uma introdução; texto integrante da obra: Participação e Deliberação - Teoria Democrática e Experiências Institucionais no Brasil Contemporâneo, COELHO, Vera Schattan P., e NOBRE, Marcos (org.), Editora 34, São Paulo, 2004, p. 26.
} 
Não é despropositado lembrar que no modelo de democracia do Welfare State, ao promover igualdade e liberdade ao cidadão o Estado implantava políticas que faziam com que o cidadão se tornasse elemento passivo nesta relação, no sentido de que se tornou "cliente" do Estado. Esta atitude paternalística acabou afastando o cidadão das decisões relevantes da vida pública, todas delegadas ao Estado, sendo certo que a intervenção do cidadão neste sistema limitou-se ao momento do voto. ${ }^{370}$

O Direito Público no Estado contemporâneo precisa extrapolar os limites da simples formalidade para atender as reais necessidades das pessoas. O Poder Público precisa ser exercido para atingir resultados legítimos, ou seja, os resultados esperados pela comunidade. $\mathrm{O}$ enfoque deve ser a finalidade a que se destina o ato e não o poder de que esteja investido o agente ou o órgão atuante. ${ }^{371}$

Este novo modelo impõe uma mudança na sistemática de tomadas de decisões, com a ampliação dos métodos de participação nas instâncias deliberativas do Estado. Nesta nova fórmula, o cidadão não se limita a reivindicar ou sofrer inerte a ação do Estado, mas coloca-se como ator integrante das tomadas de decisões, num movimento que favorece o reconhecimento de suas reivindicações como legítimas por seus pares e pela sociedade. $^{372}$

Certo é que, sem a efetiva participação popular como fator de legitimação na atuação do Estado no exercício do poder de polícia, não há que se falar realmente de um ambiente de democracia social ${ }^{373}$.

\section{V.4 - A Prática do Poder de Polícia no Estado Contemporâneo}

Exposto o tema sob o ponto de vista acadêmico, com ênfase nos fenômenos que provocaram sua transformação desde os tempos remotos, passando pelo

\footnotetext{
${ }^{370}$ NOBRE, Marcos, in Participação e Deliberação na Teoria Democrática - Uma introdução; texto integrante da obra: Participação e Deliberação - Teoria Democrática e Experiências Institucionais no Brasil Contemporâneo, COELHO, Vera Schattan P., e NOBRE, Marcos (org.), Editora 34, São Paulo, 2004, pp. $27 / 29$.

${ }^{371}$ MOREIRA NETO, Diogo de Figueiredo, Quatro Paradigmas do Direito Administrativo Pós-Moderno, Ed. Forense, Rio de Janeiro, 2008, p. 105.

372 NOBRE, Marcos, in Participação e Deliberação na Teoria Democrática - Uma introdução; texto integrante da obra: Participação e Deliberação - Teoria Democrática e Experiências Institucionais no Brasil Contemporâneo, COELHO, Vera Schattan P., e NOBRE, Marcos (org.), Editora 34, São Paulo, 2004, p. 30.

${ }^{373}$ HABERMAS, Jürgen, Direito e Democracia - entre a facticidade e validade - vol. II, Biblioteca Tempo Brasileiro, Rio de Janeiro, 2.010, p. 147.
} 
"Estado de Polícia" e pela construção da visão clássica do instituto, cumpre-nos agora destacar alguns dos aspectos práticos do exercício do poder de polícia contemporâneo que, segundo nossa ótica, merecem destaque.

\section{V.4.1 - O Poder/Dever de Agir.}

A evolução da consciência política do cidadão fez com que houvesse também uma evolução na visão a cerca dos poderes do Estado. Na verdade, não se concebe mais a atuação segundo a vontade do Estado ou do agente público, mas tão somente um "poder-dever" conferido por lei visando o atingimento do interesse público. ${ }^{374}$

Assim, ao nos referirmos a poder de polícia da Administração estamos, na verdade, aludindo a um verdadeiro poder-dever de agir da Administração que através de seus agentes deve cumprir a finalidade de estabelecer o bem-estar da coletividade, através dos meios de atuação e dos atributos desta função. ${ }^{375}$

Esta verdadeira "obrigação estatal" de exercer o poder de polícia mostra-se indispensável sempre que estiver em risco a coexistência ordenada dos atores sociais, suplantando a ideia de mera faculdade de ação, como era entendida anteriormente. $^{376}$

Tal modo de agir está inserido no que Gido Falzone ${ }^{377}$ denominava de "Il dovere di buona amministrazine", ou seja, traduz a obrigação da Administração de estabelecer de modo mais intenso e melhor possível o interesse público, o bem estar comum.

Afastando-se das concepções estritamente liberais do final do Século XVIII, a atuação do Estado, por meio do poder de polícia, regulando as mais diversas atividades sociais é fenômeno que avança, como vimos, podendo ser percebido onde quer que haja interesse social relevante.

\footnotetext{
${ }^{374}$ SIRAQUE, Vanderlei, Controle Social da Função Administrativa do Estado, Ed. Saraiva, $2^{\mathrm{a}}$ ed., São Paulo, 2009, pp. 07/08.

${ }^{375}$ ARAÚJO, Edmir Netto de, Curso de Direito Administrativo, Saraiva, 5a ed., São Paulo, 2010, p. 1052.

376 FREITAS, Juarez, Poder de Polícia Administrativa - Novas reflexões, BDA/Boletim de Direito Administrativo 6/657-668, Ed. Nova Dimensão, São Paulo, Junho de 2006, p. 660.

${ }^{377}$ FALZONE, Guido, Il dovere di buona ammnistrazione, Giufrè Editore, Milão, 1953, pp. 140/141.
} 
Eros Grau ensina que:

...tais poderes são instrumentais ao alcance das sobreditas finalidades. Sem eles, o sujeito investido na função não teria como desincumbir-se do dever posto ao seu cargo. Donde quem os titulariza maneja, na verdade "deveres-poderes" no interesse público. ${ }^{378}$

O poder de polícia é exercido hodiernamente pelo Estado em áreas como a proteção ambiental, à saúde, higiene, na limitação aos direitos de reunião e aglomerações públicas, trânsito, etc.

Em contrapartida ao alargamento de sua abrangência, o poder de polícia vai encontrar limites justamente no balizamento efetuado pela Constituição entre os direitos sociais e coletivos e os direitos individuais, consagrados especialmente no artigo $5^{\circ}$ da CF, observando-se, como visto, a predominância do interesse coletivo. ${ }^{379}$

Estabelecer o equilíbrio entre estes interesses parece ser o grande desafio da sociedade moderna, especialmente nos grandes centros urbanos.

O poder de policia expressa a necessidade de se limitar o exercício dos direitos individuais, mas com vistas a viabilizar a realização dos direitos fundamentais por toda a coletividade. Em outras palavras, tem como finalidade evitar que a expressão máxima da liberdade individual impeça ou ponha em risco a possibilidade da convivência coletiva. $^{380}$

Resta claro, pois, que o exercício do poder de polícia é dever primaz do Estado, voltado à satisfação de uma das necessidades básicas da sociedade, qual seja, o estabelecimento do equilíbrio das liberdades para tornar possível a plena convivência social.

Tão vital é o exercício deste poder/dever de agir que a Constituição Federal prevê casos em que o poder de polícia deverá ser acionado, de forma excepcional, com prejuízo momentâneo de alguns direitos. São os casos de Estado de Defesa (art. 136, I da CF) e o Estado de Sítio (art. 139, III, IV e VI da CF).

${ }^{378}$ GRAU, Eros Roberto, Poder de Polícia: Função Administrativa e Princípio da Legalidade: O Chamado “Direito Alternativo", Revista Trimestral de Direito Público, n 01/1993, Editora Malheiros, p. 93.

${ }^{379}$ ARAÚJO, Edmir Netto de, Curso de Direito Administrativo, Saraiva, 5a Ed., São Paulo, 2010, p. 1053.

${ }^{380}$ JUSTEN FILHO, Marçal, Curso de Direito Administrativo, $3^{\text {a }}$ edição, Saraiva, São Paulo, 2008, p. 460. 
Nestas hipóteses podem ser restringidos de modo mais agudo direitos como os de reunião, o sigilo de correspondência, sigilo de comunicações, à liberdade de imprensa, de radiodifusão, e a inviolabilidade de domicílio.

Cumpre consignar que mesmo nestas situações excepcionais não há que se falar abolição de direitos, mas somente de restrições, sendo certo que em qualquer hipótese os diretos fundamentais devem ser preservados. ${ }^{381}$

De notar-se que as garantias constitucionais realmente podem ser suspensas nestes casos, porém, com a devida autorização do Congresso Nacional. Vale frisar também que mesmo nestes casos, não se cogita a exclusão do controle judicial sobre os atos praticados. ${ }^{382}$

\section{V.4.2 - Atividade Privativamente Pública - Possibilidades de Delegação}

Já há muito se consolidou a noção de que os atos que expressam o poder de polícia, por serem dotados dos atributos da supremacia geral, via de regra, não poderiam ser delegados a particulares. ${ }^{383}$ Justamente por esta razão (por ter como fundamento a supremacia geral da Administração), a princípio, não poderia ser transferida a terceiros, sob pena de restar ferida a isonomia entre os particulares. ${ }^{384}$

E é justamente este ponto que merece ser analisado com todo cuidado. Conforme alertou Juarez Freitas, de fato, o poder de polícia é indelegável, porém, somente naquilo que intrinsecamente manifesta a "estatalidade que o justifica". 385

Há que se ter em mente que muito embora o poder de polícia seja de fato uma atividade privativa da Administração ${ }^{386}$ e exercida em nome da supremacia geral, tal constatação jamais afastou a possibilidade de delegação nos limites e hipóteses legais ${ }^{387}$.

\footnotetext{
${ }^{381}$ MEDUAR, Odete, Direito Administrativo Moderno, $3^{\text {a }}$ ed., São Paulo, 1999, p. 375.

${ }^{382}$ FIGUEIREDO, Lúcia Valle, Curso de Direito Administrativo, $9^{\mathrm{a}}$ edição, Malheiros, São Paulo, 2008, p. 284.

383 BANDEIRA DE MELlo, Celso Antônio, Curso de Direito Administrativo, Malheiros, $21^{\text {a }}$ Ed., São Paulo, 2006, p. 797.

${ }^{384}$ FERREIRA, Daniel, Poder de Polícia, in Curso de Direito Administrativo, Marcelo Harger (org.) Ed. Forense, Rio de Janeiro, 2007, p. 373.

${ }^{385}$ FREITAS, Juarez, Poder de Polícia Administrativa - Novas Reflexões, BDA/Boletim de Direito Administrativo 6/657-668, Ed. Nova Dimensão, São Paulo, Junho de 2006, p. 664

${ }^{386}$ CIRNE LIMA, Ruy, Princípios de Direito Administrativo, Malheiros Editores, 5ª Ed., São Paulo, 1982, p. 107.

${ }^{387}$ ARAÚJO, Edmir Netto de, Curso de Direito Administrativo, Saraiva, 5a Ed., São Paulo, 2010, p. 1048.
} 
De fato, a análise mais acurada do instituto permite concluir que sempre foi possível a delegação daqueles atos que não correspondam ao núcleo da manifestação de poder ou dos atos de autoridade. Em outras palavras, são passíveis de delegação os atos materiais precedentes ou posteriores aos atos decisórios de polícia, atos que, em geral, limitem-se à mera constatação e que, por isto, não ponham em risco a impessoalidade. $^{388}$

Vale o registro de que há inclusive atos matérias que podem ser expedidos por meio de máquinas, de modo automático, sem que haja qualquer ofensa a direitos ou aos princípios que regem o poder de polícia $^{389}$.

Dinorá Adelaide Grotti ${ }^{390}$ ensina que somente o "núcleo em si da atividade de limitação administrativa" é que não pode ser delegado. Os atos que não expressam uma coerção, por não constituírem o cerne do ato de polícia, não precisam necessariamente ser praticados por agentes públicos. ${ }^{391}$

Com efeito, há atos materiais que, por representarem simples exercícios de constatação, podem ser delegados por meio de "credenciamentos" ou através de contratação para prestação de serviços. ${ }^{392}$

É certo que devem limitar-se à colheita de dados, conferência, medição, identificação de pessoas e documentos e procedimentos semelhantes. Tal cuidado milita justamente em favor da impessoalidade na atuação do particular que age sob delegação. $^{393}$

Nestes casos, não se atribui ao terceiro (delegatário) qualquer poder de expressão de vontade ou expedição de sanção, mas tão somente a execução de atos matérias cujos padrões a serem aferidos, são estabelecidos e fiscalizados pelo Poder Público. Também por este prisma é garantida a isonomia e a impessoalidade, não havendo que se falar em desequilíbrio. ${ }^{394}$

\footnotetext{
${ }^{388}$ PIRES, Luis Manuel Fonseca, Limitações Administrativas à Liberdade e à Propriedade, Quartier Latin, São Paulo, 2006, p. 227.

389 O exemplo é de: BANDEIRA DE MELlo, Celso Antônio, Serviço Público e Poder de Polícia: Concessão e Delegação, in Revista Eletrônica de Direito do Estado, $n^{\circ}$ 7, julho/setembro, Salvador, 2006, p. 08 .

${ }^{390}$ GROTTI, Dinorá Adelaide Musetti, Poder de Polícia - Palestra proferida no Seminário Nacional de Direito Administrativo - Edição Comemorativa dos 20 anos da NDI, BDS/Boletim de Direito Administrativo, 7/753-758, Ed. Nova Dimensão Jurídica, Junho 2006, p. 757.

${ }^{391}$ JUSTEN FILHO, Marçal, Curso de Direito Administrativo, $3^{\text {a }}$ edição, Saraiva, São Paulo, 2008, p. 473.

392 BANDEIRA DE MELLO, Celso Antônio, Serviço Público e Poder de Polícia: Concessão e Delegação, in Revista Eletrônica de Direito do Estado, $n^{\circ}$ 7, julho/setembro, Salvador, 2006, p. 07.

${ }^{393}$ PESTANA, Márcio, Direito Administrativo Brasileiro, Campus Jurídico, Rio de Janeiro, 2008, p. 502.

${ }^{394}$ BANDEIRA DE MELlO, Celso Antônio, Curso de Direito Administrativo, Malheiros, $21^{\mathrm{a}}$ Ed., São Paulo, 2006, p. 797.
} 
Não é dispensável repisar que, por natureza, a manifestação do poder de império do Estado jamais pode ser delegado quanto ao seu cerne. Não são delegáveis os atos que exprimem a vontade impositiva da autoridade pública. ${ }^{395}$

Neste sentido, vale destacar a recente e emblemática decisão proferida pelo Superior Tribunal de Justiça, no Recurso Especial n ${ }^{\circ}$ 817.534-MG, em que se discutiu a (im)possibilidade de delegação do poder de polícia na hipótese de aplicação de sanções de trânsito por empresa constituída como sociedade de economia mista:

“RECURSO ESPECIAL N 817.534 - MG (2006/0025288-1)

RELATOR : MINISTRO MAURO CAMPBELL MARQUES

RECORRENTE : MINISTÉRIO PÚBLICO DO ESTADO DE MINAS GERAIS

RECORRIDO : EMPRESA DE TRANSPORTE E TRÂNSITO DE BELO

HORIZONTE - BHTRANS

ADVOGADO : EDUARDO AUGUSTO VIEIRA DE CARVALHO E $\operatorname{OUTRO}(S)$

EMENTA:

ADMINISTRATIVO. PODER DE POLÍCIA. TRÂNSITO. SANÇÃO PECUNIÁRIA APLICADA POR SOCIEDADE DE ECONOMIA MISTA.IMPOSSIBILIDADE.

1. Antes de adentrar o mérito da controvérsia, convém afastar a preliminar de conhecimento levantada pela parte recorrida. Embora o fundamento da origem tenha sido a lei local, não há dúvidas que a tese sustentada pelo recorrente em sede de especial (delegação de poder de polícia) é retirada, quando o assunto é trânsito, dos dispositivos do Código de Trânsito Brasileiro arrolados pelo recorrente (arts. 21 e 24), na medida em que estes artigos tratam da competência dos órgãos de trânsito. $O$ enfrentamento da tese pela instância ordinária também tem por conseqüencia o cumprimento do requisito do prequestionamento.

2. No que tange ao mérito, convém assinalar que, em sentido amplo, poder de polícia pode ser conceituado como o dever estatal de limitar-se o exercício da propriedade e da liberdade em favor do interesse público. A controvérsia em debate é a possibilidade de exercício do poder de

395 BANDEIRA DE MELLO, Celso Antônio, Serviço Público e Poder de Polícia: Concessão e Delegação, in Revista Eletrônica de Direito do Estado, nº 7, julho/setembro, Salvador, 2006, p. 08. 
polícia por particulares (no caso, aplicação de multas de trânsito por sociedade de economia mista).

3. As atividades que envolvem a consecução do poder de polícia podem ser sumariamente divididas em quatro grupo, a saber: (i) legislação, (ii) consentimento, (iii) fiscalização e (iv) sanção.

4. No âmbito da limitação do exercício da propriedade e da liberdade no trânsito, esses grupos ficam bem definidos: o CTB estabelece normas genéricas e abstratas para a obtenção da Carteira Nacional de Habilitação (legislação); a emissão da carteira corporifica a vontade o Poder Público (consentimento); a Administração instala equipamentos eletrônicos para verificar se há respeito à velocidade estabelecida em lei (fiscalização); e também a Administração sanciona aquele que não guarda observância ao CTB (sanção).

5. Somente o atos relativos ao consentimento e à fiscalização são delegáveis, pois aqueles referentes à legislação e à sanção derivam do poder de coerção do Poder Público.

6. No que tange aos atos de sanção, o bom desenvolvimento por particulares estaria, inclusive, comprometido pela busca do lucro aplicação de multas para aumentar a arrecadação.

7. Recurso especial provido. (g.n.) $)^{396}$

Nesta linha, é que se toma por inconstitucional o artigo $280, \S 4^{\circ}$ do Código Nacional de Trânsito que prevê a possibilidade de delegação das funções de autoridade a funcionários celetistas. Pelo mesmo motivo alguns entendem indelegáveis as funções de administração e vigilância das muralhas de presídios. ${ }^{397}$

Oportuna ainda a ressalva de que os atos materiais que compõem a atividade de polícia e podem ser delegados não podem envolver a limitação a liberdade pessoal $^{398}$, ou seja, só podem incidir sobre o patrimônio dos particulares. É o caso da

\footnotetext{
${ }^{396}$ Esta decisão, alcançada pelo Ministério Público do Estado de Minas Gerais e que na prática ocasionará a anulação de milhares de multas de trânsito aplicadas pela concessionária Empresa de Transportes e Trânsito de Belo Horizonte S/A - BHTrans., encontra-se sob análise do STF por força da Reclamação 9.702(66) (Rel. Min. Luiz Fux)

${ }^{397}$ PIRES, Luis Manuel Fonseca, Limitações Administrativas à Liberdade e à Propriedade, Quartier Latin, São Paulo, 2006, p. 238.

${ }^{398}$ No mesmo sentido: PIRES, Luis Manuel Fonseca, Limitações Administrativas à Liberdade e à Propriedade, Quartier Latin, São Paulo, 2006, p. 228.
} 
contratação de empresa para efetuar demolição de imóvel, ou a retiradas de antenas de rádio transmissão instaladas irregularmente. ${ }^{399}$

Fato é que os atos típicos do exercício do poder de polícia (cerne do ato) só podem ser praticados por agentes públicos, titulares de cargo público. Isto porque seria totalmente incoerente atribuir o exercício de um poder a quem não possui estabilidade na função pública.

Em suma, é possível concluir pela possibilidade da delegação de atos materiais-instrumentais, preparatórios ou sucessivos ao exercício do poder de polícia, não se cogitando, porém, a hipótese da delegação do poder de polícia em si. ${ }^{400}$

\section{V.4.3 - A Omissão quanto ao Exercício do Poder de Polícia e suas Consequências}

Nas palavras de Cretella Jr., o poder de polícia constitui-se em:

...condição sine qua non para a coexistência dos agrupamentos humanos, é a potestas que paira acima dos aparelhamentos policiais dos diversos povos, assentando-se em postulados da razão prática. ${ }^{401}$

Tomando, pois, o poder de polícia como uma das funções mais relevantes para o estabelecimento do desejado equilíbrio entre os reais interesses públicos e os direitos e garantias individuais e tendo em vista que o seu exercício é, na verdade, um poder-dever do Estado, mister se faz ponderar a respeito das consequências que a omissão da Administração poderá gerar.

É questão de lógica jurídica e até sociológica que num ambiente democrático e de direito, uma das preocupações do Estado deve ser a de atuar para implementar políticas públicas que atendam aos anseios coletivos, porém sem abrir mão da proteção aos indivíduos que compõem esta sociedade.

Iara Leal Gasos afirma em obra dedicada ao assunto que:

\footnotetext{
399 BANDEIRA DE MELLO, Celso Antônio, Curso de Direito Administrativo, Malheiros, 21 a Ed., São Paulo, 2006, p. 798.

${ }^{400}$ BANDEIRA DE MELlo, Celso Antônio, Curso de Direito Administrativo, Malheiros, $21^{\text {a }}$ Ed., São Paulo, 2006, p. 799.

401 CRETELLA JR., José, Direito Administrativo Brasileiro, Editora Forense, $2^{\text {a }}$ edição, Rio de Janeiro 2.000 , pp. 548/549.
} 
Destarte, entende-se que, onde ocorre o poder-dever de agir do estado, nos diversos casos onde é ausente o poder de polícia na sua proteção e fiscalização, enseja a discussão sobre se a omissão seria a título de culpa (latu sensu), vista do ângulo da discricionariedade da Administração, e se a sua inércia em prevenir o dano, onde há perigo iminente, gera direito subjetivo ao particular para acionar o Judiciário, a compelir a atuação da Administração. ${ }^{402}$

No texto citado encontram-se os elementos para nossa ponderação: a natureza de poder-dever do poder de polícia; o limite de sua discricionariedade e o direito subjetivo que o individuo possui de acionar o Estado, inclusive judicialmente em caso de inação.

De fato, ao atribuir o exercício de um poder ou função a determinado agente ou órgão público, a lei impõe que tal desiderato seja cumprido fielmente, em toda sua plenitude, nos moldes e no tempo estabelecidos. Nas palavras de Diógenes Gasparini:

Não se satisfaz o Direito com desempenho incompleto ou a destempo da competência e, pior ainda, com a omissão da autoridade. Não se aceita a possibilidade, sequer, de o agente público praticar intempestivamente atos de sua competência quando ocorre a oportunidade de agir, como não se entende que só se desincumba de parte de sua obrigação ou se abstenha em relação a essa obrigação. ${ }^{403}$

Conforme vimos, o poder de polícia, num Estado Democrático só pode ser tomado como um instrumento colocado a disposição da Administração e em favor dos cidadãos, para ser utilizado obrigatoriamente, sempre que a lei assim o determinar e a situação fática assim o exigir. Tal afirmação decorre, entre outros fatores, do dever de boa administração do Estado, do qual ele não pode abrir mão.

Restando adstrito ao princípio da legalidade administrativa, e tomado como um poder-dever, qualquer omissão do Poder Público será tomado como afrontoso à lei, tornando a conduta do agente desidioso passível de ser exigida judicialmente.

402 GASOS, Iara Leal, A Omissão Abusiva do Poder de Polícia, Lumen Juris, Rio de Janeiro, 1994, p. 03.

${ }^{403}$ GASPARINI, Diógenes, Direito Administrativo, $7^{\mathrm{a}}$ ed., Saraiva, São Paulo, 2002, p. 139. 
Neste sentido, Iara Gasos ${ }^{404}$, aludindo ao artigo 37 da Constituição

afirma que:

Não há ramo do Direito que não se fundamente no princípio da legalidade, razão pela qual o pleonasmo enfático de sua reiteração no capítulo da Administração objetiva afastar qualquer tentação hermenêutica do intérprete oficial de que seu poder discricionário poderia lhe permitir atuar fora da lei, em determinadas circunstâncias, ou de que a lei só seria aplicável aos atos vinculados, e nunca àqueles dele originários. É hoje mansa e pacífica a doutrina de que o poder discricionário - e há autores que nem a expressão "ato discricionário" aceitam - é um poder alicerçado na lei.

Vale aqui transcrever trecho de recente decisão proferida pelo Superior Tribunal de Justiça, no Recurso Especial 958641-PI em que tal questão é abordada de forma cristalina:

RECURSO ESPECIAL N 5 . 41 - PI (2007/0130282-0)

RELATORA: MINISTRA DENISE ARRUDA

RECORRENTE: AGÊNCIA NACIONAL DE TELECOMUNICAÇÕES ANATEL

PROCURADOR: FLÁVIO MARCELO SÉRVIO BORGES E $\operatorname{OUTRO}(\mathrm{S})$

RECORRIDO: FUNDAÇÃO CULTURAL DE RADIODIFUSÃO VALENCIANA

ADVOGADO: ANDRÉIA NÁDIA LIMA DE SOUSA E OUTRO(S)

EMENTA:

4. Considerando que a legislação em vigor estabelece a competência do Poder Executivo para autorizar, conceder e fiscalizar o serviço de radiodifusão sonora e de sons e imagens, não pode o Poder Judiciário imiscuir-se no âmbito da discricionariedade da Administração Pública, deferindo pedido de funcionamento, ainda que a título precário, de rádio comunitária. Ao Judiciário apenas é permitido, em caso de demora na análise de requerimento administrativo de autorização para seu

${ }^{404}$ GASOS, Iara Leal, A Omissão Abusiva do Poder de Polícia, Lumen Juris, Rio de Janeiro, 1994, p. 62. 
funcionamento, o reconhecimento de omissão por parte da autoridade competente, estipulando prazo razoável para que se pronuncie sobre o respectivo requerimento"

Dentro deste prisma, se o Estado se omite, causando prejuízo ou colocando em risco os indivíduos ou seus direitos, fica sujeito a ver-se compelido a praticar o ato omitido ou arcar com as consequências de sua omissão.

Isto porque, não havendo mais possibilidade de praticar o ato, ficará sujeito a responder pelos prejuízos causados por sua conduta omissiva. Ora, se o exercício do poder de polícia é dever do Estado, decorre desse dever o direito (a garantia) para o administrado de que seja prestado a contento. Bem por isto, da omissão da Administração, decorrerá o direito do indivíduo de exigir uma atuação eficaz ou no caso de ocorrem danos "não eventuais", de exigir o ressarcimento correspondente ${ }^{405}$.

Maria Sylvia Zanella Di Pietro nos traz outro excelente exemplo sobre a questão:

...a omissão do Estado em retirar os invasores de áreas públicas, que ali constroem ilegalmente causando danos, já constitui, por si, fundamento suficiente para ensejar a responsabilidade civil, facilmente imputável ao Estado, por meio de ação civil pública. ${ }^{406}$

Com efeito, é preciso ter em mente que a atuação do Poder Público na proteção do interesse coletivo e em defesa da manutenção dos bens que são caros à sociedade constitui-se em muito mais do que uma mera expectativa. É, na verdade, uma garantia constitucional das mais vitais, traduzindo uma das mais fundamentais finalidades da Administração, daí não haver que se falar em discricionariedade desta atuação.

Certo é que não se tolera mais a ideia de um Estado inerte frente às questões sociais a que deve regular. Levando em conta que o poder de polícia é exercido justamente para manter a coesão entre os interesses sociais coletivos e os direitos e garantias individuais, não há como se conformar com uma Administração passiva frente às

${ }^{405}$ FREITAS, Juarez, Poder de Polícia Administrativa - Novas Reflexões, BDA/Boletim de Direito Administrativo 6/657-668, Ed. Nova Dimensão, São Paulo, Junho de 2006, p. 660.

${ }_{406}$ DI PIETRO, Maria Sylvia Zanella, Poder de Polícia, in Revista de Direito Público, São Paulo, v 24, no 98, pg. 90-4, abr/jun. 1991, p. 92. 
graves e complexas questões que se colocam. Eventual fraqueza do Estado certamente produzirá desequilíbrios e desajustes de graves proporções. ${ }^{407}$

O que expressamos aqui é que restou consagrado um verdadeiro direito subjetivo do cidadão ao efetivo e correto exercício do poder de polícia por parte do Estado, direito este que poderá ser reclamado, sendo o caso, pelas vias judiciais. ${ }^{408}$

\section{V.4.4 - A Questão da Autoexecutoriedade no exercício do Poder de Polícia.}

A autoexecutoriedade, que a professora Odete Medauar ${ }^{409}$ chama de "execução destitulada", se caracteriza e se destaca pelo fato de que a administração, especialmente em momentos de urgência, precisa agir de forma rápida e eficaz, não podendo ficar sujeita a prévia apreciação judicial ${ }^{410}$ de seus atos. ${ }^{411}$ Uma vez previsto em lei e praticado por agente competente, não necessita de qualquer autorização de outro Poder para ser levado a efeito. ${ }^{412}$

A autoexecutoriedade é justamente o atributo que garante a pronta e contundente ação da Administração Pública. ${ }^{413}$

${ }^{407}$ GASOS, Iara Leal, A Omissão Abusiva do Poder de Polícia, Lumen Juris, Rio de Janeiro, 1994, pp. 6/7 ${ }^{408}$ GASOS, Iara Leal, A Omissão Abusiva do Poder de Polícia, Lumen Juris, Rio de Janeiro, 1994,, p. 100.

${ }^{409}$ MEDUAR, Odete, Auto-executoriedade do Ato Administrativo, in Boletim de Direito Administrativo, v. 2, p 515-519, julho de 1986, p. 516.

${ }^{410}$ Neste sentido:

“RECURSO ESPECIAL № 696.993 - SP (2004/0147952-0)

RELATORA : MINISTRA ELIANA CALMON

RECORRENTE : MUNICÍPIO DE SÃO PAULO

RECORRIDO : COMÉRCIO DE PEÇAS E ACESSÓRIOS ESTRELA DE OURO

LTDA

VOTO

A EXMA. SRA. MINISTRA ELIANA CALMON (Relatora):

Prequestionado, ainda que implicitamente, a tese em torno dos dispositivos indicados no especial, conheço do recurso especial.

É sabido que os atos administrativos gozam dos atributos da presunção de legitimidade, imperatividade, exigibilidade e executoriedade.

Tais atributos conferem à Administração Pública a qualidade pela qual pode compelir materialmente o administrado ao seu cumprimento sem a necessidade de buscar previamente as vias judiciais, independentemente da sua concordância e com presunção júris tantum de legitimidade.

Por essa razão, entendo que não há interesse da Fazenda Pública de recorrer à via judicial, pois, como frisou o Tribunal de origem, a tutela jurisdicional limitar-se-ia a expedir ordem de intervenção policial para cumprir ato administrativo para interdição e fechamento de edifício irregular, providência que a própria Administração pode tomar, em decorrência do seu poder de polícia, de acordo com as competências a ela delegadas pela legislação pertinente.

Com essas considerações, nego provimento ao recurso especial.

É o voto."

${ }^{411}$ BEZNOS, Clóvis, Poder de Polícia, Revista dos Tribunais, São Paulo, 1979, p. 36.

${ }^{412}$ PESTANA, Márcio, Direito Administrativo Brasileiro, Campus Jurídico, Rio de janeiro, 2008, p. 495.

${ }^{413}$ MORAES, Alexandre de, Direito Constitucional Administrativo, $4^{\text {a }}$ ed., Atlas, São Paulo, 2007, p. 107. 
Cretella Junior que trata a autoexecutoriedade como uma prerrogativa da Administração ${ }^{414}$ assinala que ela pode ser conhecida também como:

...privilégio de ação de ofício, privilégio da execução prévia, privilégio do prévio ou privilégio do preliminar (priviège du préalable ou previlège d'execution d'offiice) ${ }^{415}$

Há autores que assinalam que a executoriedade é mais do que a exigibilidade, pois a executoriedade é a prerrogativa de que dispõe a Administração de, na forma da lei, usar de meios próprios para obrigar ao particular a fazer ou deixar de fazer algo. Em outras palavras, é o poder de, por meios próprios, coagir o administrado a cumprir suas determinações. ${ }^{416}$

Levando em conta que o poder de polícia é uma função estatal destinada a garantir o bem estar coletivo, é natural que a Administração possa exercê-la gozando de meios de atuação que lhe proporcione agilidade, sob pena de restar ineficaz a medida. $^{417}$

Na verdade, como lembra Odete Medauar ${ }^{418}$, remetendo às lições de Ranelletti, a possibilidade de executar por si mesma os atos necessários ao atingimento das finalidades públicas é inerente ao próprio conceito de poder, sendo mesmo elemento essencial dele.

Em decorrência deste atributo, a administração pode agir tanto repressivamente, coibindo pela força a pratica de alguma atividade nociva, quanto através de meios coercitivos indiretos, como por exemplo, impondo determinadas proibições ou condutas sob pena de imposição de sanção pecuniária. A coercibilidade, portanto, é inerente à característica da autoexecutoriedade dos atos de polícia do Estado. ${ }^{419}$

\footnotetext{
${ }^{414}$ No mesmo sentido: MEDUAR, Odete, Auto-executoriedade do Ato Administrativo, in Boletim de Direito Administrativo, v. 2, p 515-519, julho de 1986, p. 517.

415 CRETELLA JR, José, Prerrogativas e Sujeições da Administração Pública, in Revista de Direito Administrativo, volume 103m Rio de Janeiro, janeiro a março de 1971, p. 21.

${ }^{416}$ SUNDFELD, Carlos Ari, Direito Administrativo Ordenador, Malheiros Editores, São Paulo, 2003, p. 82.

${ }^{417}$ BANDEIRA DE MELLO, Celso Antônio, Curso de Direito Administrativo, Malheiros, $21^{\mathrm{a}}$ Ed., São Paulo, 2006, p. 799.

${ }^{418}$ MEDUAR, Odete, Auto-executoriedade do Ato Administrativo, in Boletim de Direito Administrativo, v. 2, p 515-519, julho de 1986, p. 517.

${ }_{419}$ ARAÚJO, Edmir Netto de, Curso de Direito Administrativo, Saraiva, 5a Ed., São Paulo, 2010, p. 1050.
} 
É precisa a lição de Cretella Jr. quando afirma que:

No vasto e importante campo do poder de polícia, explicitado nos diversos ramos em que se desdobra a polícia administrativa, a autoexecutoriedade aparece com toda sua força, legitimando as providências rápidas do Poder Executivo, quando edita atos administrativos e imediatamente os faz atuar, no mundo jurídico. ${ }^{420}$

A autoexecutoriedade, porém, é atributo que demanda uma especial atenção, pois não são todos os atos de limitação da liberdade e direitos que podem ser levados a efeito através deste mecanismo.

Com efeito, só é viável a prática do ato de polícia por meio da autoexecutoriedade no caso de haver lei prevendo tal medida ou quando a situação de fato indicar a medida como único meio de se evitar um dano maior à coletividade, de forma que a busca da decisão judicial seja inviável. ${ }^{421}$

Nos casos de urgência, portanto, há uma presunção de legalidade da atuação, exigindo-se que no conflito de direitos em questão, prevaleça o interesse público atingido de forma excepcional e que não seja possível sanar o conflito em favor da coletividade através de outros mecanismos legais. ${ }^{422}$

O recurso à força, assim, deve ser a última hipótese, quando não há mais outro meio de se atingir a finalidade pública. ${ }^{423}$ De outro modo, acabaria por ferir o princípio do devido processo legal previsto pelo artigo $5^{\circ}$, inciso LIV da Constituição Federal.

Quanto a este aspecto, o STF teve oportunidade de se manifestar através da ADIN 1.668-5/DF em que eram questionados diversos dispositivos da Lei Federal 9.472/98, em especial o inciso XV do artigo $19^{424}$, que atribuía a ANATEL, no

${ }^{420}$ CRETELLA JR, José, Prerrogativas e Sujeições da Administração Pública, in Revista de Direito Administrativo, volume 103, Rio de Janeiro, janeiro a março de 1971, p. 22.

${ }^{421}$ GROTTI, Dinorá Adelaide Musetti, Poder de Polícia - Palestra proferida no Seminário nacional de Direito Administrativo - Edição Comemorativa dos 20 anos da NDI, BDS/Boletim de Direito Administrativo, 7/753-758, Ed. Nova Dimensão Jurídica, Junho 2006, p. 754.

${ }^{422}$ PIRES, Luis Manuel Fonseca, Limitações Administrativas à Liberdade e à Propriedade, Quartier Latin, São Paulo, 2006, pp. 208/213.

${ }^{423}$ MEDUAR, Odete, Auto-executoriedade do Ato Administrativo, in Boletim de Direito Administrativo, v. 2, p 515-519, julho de 1986, p. 518.

${ }^{424}$ Art. 19. "À Agência compete adotar as medidas necessárias para o atendimento do interesse público e para o desenvolvimento das telecomunicações brasileiras, atuando com independência, imparcialidade, legalidade, impessoalidade e publicidade, e especialmente: 
exercício do poder de polícia, a competência para proceder à busca e apreensão de bens tendo suspendido a eficácia da norma.

Do voto vencedor do Ministro Marco Aurélio ${ }^{425}$, relator do caso, podemos extrair claramente que a evocação à autoexecutoriedade do poder de polícia não prevalece por si só em detrimento do devido processo legal quando a observância do mesmo é viável:

Quanto ao inciso XV, exsurge a relevância do pedido formulado. A rigor, o que se tem, na espécie, é o exercício, pela Administração Pública, de maneira direta, a alcançar patrimônio privado, de direito inerente à atividade que exerce. Se de um lado à Agência cabe a fiscalização da prestação de serviços, de outro não se pode compreender, nela, a realização de busca e apreensão de bens de terceiros. A legitimidade diz respeito à provocação mediante o processo próprio, buscando-se alcançar, no âmbito do Judiciário, a ordem para que ocorra o ato de constrição, que é o de apreensão de bens. O dispositivo acaba por criar, no campo da administração, figura que, em face das repercussões pertinentes, a de ser sopesada por órgão independente e, portanto, pelo Estado-Juiz. Diante de tais premissas, defiro parcialmente a liminar para suspender, no artigo 19 da Lei 9.472, de 16 de julho de 1997, a eficácia do inciso XV, no que atribuída à ANATEL, isto é, à Agência Nacional de Telecomunicações, a possibilidade de empreender a busca e apreensão de bens. Entendo que a norma contraria o inciso LIV do artigo $5^{\circ}$ da Constituição Federal, que encerra a garantia de que ninguém será privado da liberdade ou de seus bens sem o devido processo legal.

A professora Dinorá Adelaide Grotti nos fornece outro bom exemplo da forma como deve ser interpretada esta prerrogativa da Administração. Tratando do conflito de interesses entre a inviolabilidade do domicílio e a autoexecutoriedade dos atos de polícia ela é taxativa:

Eu entendo que diante do art. $5^{\circ}$, inciso XI, da Constituição, diante do desastre ou de calamidade já ocorrida, ou durante sua ocorrência ou

\footnotetext{
XV - realizar busca e apreensão de bens no âmbito de sua competência "

${ }^{425}$ A referida norma posteriormente foi revogada pela Lei $11.292 / 06$ que passou a prever somente a apreensão de bens dando ensejo a novos questionamentos junto ao STF (p.ex. Rcl. 5310, Rel. Min. Carmen Lúcia)
} 
quando esteja nas vias iminentes de ocorrer, é lícito à Administração, a autoridade pública investida da chamada polícia administrativa, penetrar na casa do particular ou no seu estabelecimento e adotar as medidas de polícia necessárias, mesmo compulsoriamente, independentemente do recurso à vias judiciais. ${ }^{426}$

Este também é o entendimento de Maria Sylvia Zanella Di Pietro, que em Parecer quanto à possibilidade do uso do poder de polícia para a remoção imediata e compulsória de moradores de áreas de risco assim se manifestou:

Quer dizer que diante do desastre ou da calamidade já ocorrida ou durante a sua ocorrência, ou quando esteja em vias iminentes de ocorrer, é lícito a autoridade pública investida do Poder de Polícia penetrar na casa particular e remover as pessoas, mesmo compulsoriamente, independentemente de recurso às vias judiciais. ${ }^{427}$

Ainda assim, vale a ponderação de que mesmo nos casos em que a urgência ou a legislação permitam o exercício das limitações de modo autoexecutável, não restam dispensados os mecanismos do devido processo legal que, tão somente, são protelados para momento mais oportuno, em seguida a realização material da medida constritiva. $^{428}$

É oportuno frisar que, mesmo nos casos em que o poder de polícia deva ser utilizado de modo autoexecutável, a Administração precisará ter disponível prontamente os meios para conter possíveis abusos. ${ }^{429}$

Por outro lado, ainda que premente o dano que pretende evitar, a ação administrativa deverá guardar proporcionalidade em relação ao benefício que

${ }^{426}$ GROTTI, Dinorá Adelaide Musetti, Poder de Polícia - Palestra proferida no Seminário nacional de Direito Administrativo - Edição Comemorativa dos 20 anos da NDI, BDS/Boletim de Direito Administrativo, 7/753-758, Ed. Nova Dimensão Jurídica, Junho 2006, p. 756.

${ }^{427}$ DI PIETRO, Maria Sylvia Zanella, Poder de Polícia, in Revista de Direito Público, São Paulo, v 24, n ${ }^{\circ}$ 98, pg. 90-4, abr/jun. 1991, p. 91.

${ }^{428}$ PIRES, Luis Manuel Fonseca, Limitações Administrativas à Liberdade e à Propriedade, Quartier Latin, São Paulo, 2006, p. 250. No mesmo sentido: FERREIRA, Daniel, Poder de Polícia, in Curso de Direito Administrativo, Marcelo Harger (org.) Ed. Forense, Rio de Janeiro, 2007, p. 375.

429 FREITAS, Juarez, Poder de Polícia Administrativa - Novas Reflexões, BDA/Boletim de Direito Administrativo 6/657-668, Ed. Nova Dimensão, São Paulo, Junho de 2006, p. 664. 
pretende alcançar, devendo restar comprovado que não existia forma melhor de se alcançar o bem estar da coletividade. ${ }^{430}$

É oportuno notar também que, a despeito da clareza de entendimento sobre as prescrições do art. $5^{\circ}$, XI da Constituição, a norma não pode ser interpretada como extensível aos casos de perigos previsíveis e não iminentes, sendo vedado à legislação infraconstitucional prever outras situações autorizadoras da atuação autoexecutória da Administração. Assim, não sendo o caso de iminência de risco, a atuação da Administração deverá ser precedida de autorização judicial para avançar sobre a propriedade ou liberdade do indivíduo. ${ }^{431}$

É certo ainda que os particulares que eventualmente se sintam lesados em seus direitos em razão da atuação administrativa no exercício do poder de polícia podem socorrer-se a posteriori do judiciário, para pleitear a reparação do dano sofrido. $^{432}$

O que ocorre no caso é uma "incompetência temporal" 433 do Poder Judiciário que só terá lugar para atuar após a execução do ato de polícia, mediante provocação. Tal situação se coloca justamente em face da urgência com que os atos autoexecutáveis são levados a efeito.

Do ponto de vista dogmático, cabe ainda a ressalva de que a autoexecutoriedade não pode ser considerada característica própria (exclusiva) do poder de polícia. Isto porque, não é atributo exclusivo desta função do Estado, podendo inclusive ser percebida no campo do direito privado, como no caso da legítima defesa. ${ }^{434}$

Este também é o entendimento de Diógenes Gasparini ${ }^{435}$ para quem nem a autoexecutoriedade nem a proporcionalidade podem ser tomados como critério para qualificar um ato como de ato de polícia.

Por fim, é oportuna a observação de que as multas decorrentes do exercício do poder de polícia não são autoexecutáveis ${ }^{436}$. Recusando-se o infrator a paga-

\footnotetext{
${ }^{430}$ BANDEIRA DE MELLO, Celso Antônio, Curso de Direito Administrativo, Malheiros, 21 a Ed., São Paulo, 2006, p. 799.

${ }^{431}$ PIRES, Luis Manuel Fonseca, Limitações Administrativas à Liberdade e à Propriedade, Quartier Latin, São Paulo, 2006, pp. 218

432 BANDEIRA DE MELlo, Celso Antônio, Curso de Direito Administrativo, Malheiros, $21^{\text {a }}$ Ed., São Paulo, 2006, p. 799.

No mesmo sentido: LAZZARINI, Álvaro, Temas de Direito Administrativo, $2^{\mathrm{a}}$ ed., Editora Revista dos Tribunais, São Paulo, 2003, p. 267.

${ }^{433}$ MEDUAR, Odete, Auto-executoriedade do Ato Administrativo, in Boletim de Direito Administrativo, v. 2, p 515-519, julho de 1986, p. 519.

${ }^{434}$ BEZNOS, Clóvis, Poder de Polícia, Revista dos Tribunais, São Paulo, 1979. pp. 36/40.

${ }^{435}$ GASPARINI, Diogenes, Direito Administrativo, $7^{\mathrm{a}}$ ed., Saraiva, São Paulo, 2002, p. 125.
} 
las, terá a administração que cobrá-la através de meios judiciais, após o devido processo legal. $^{437}$

\section{V.4.5 - O Abuso e o Desvio de Poder de Polícia - A Descaracterização do Instituto.}

Conforme podemos encontrar nas lições de Norberto Bobbio a expressão "poder" deriva do grego Krátos, que remete a idéia de "força", "potência" e de "arché", donde derivou o termo "autoridade". De modo muito perspicaz o mencionado mestre explica que;

Não há teoria política que não parta de alguma maneira, direta ou indiretamente, de uma definição de "poder" e de uma análise do fenômeno do poder. ${ }^{438}$

Cretella Júnior $^{439}$, por sua vez, nos remete à doutrina francesa que emprega as expressões puisssance, para se referir à potestade e pouvoir que em sentido técnico denota a noção de poder, para explicar que em razão da potestade pública (puissance publique) o Estado se desnivela do particular se qualificando como Poder Público, impondo sua vontade.

Mesmo sabendo que nem sempre a palavra poder é usada com o mesmo significado pelo direito público ${ }^{440}$, fato é que, conforme já vimos, o poder é substância tão inerente ao Estado que, sem este, o Estado sequer existiria.

Na verdade o poder é uma necessidade social, na medida em que é através dele que o Estado impõe o concerto que torna possível uma vida melhor aos homens. $^{441}$

\footnotetext{
${ }^{436}$ No mesmo sentido: GROTTI, Dinorá Adelaide Musetti, Poder de Polícia - Palestra proferida no Seminário Nacional de Direito Administrativo - Edição Comemorativa dos 20 anos da NDI, BDS/Boletim de Direito Administrativo, 7/753-758, Ed. Nova Dimensão Jurídica, Junho 2006, p. 756.

${ }^{437}$ FERREIRA, Daniel, Poder de Polícia, in Curso de Direito Administrativo, Marcelo Harger (org.) Ed. Forense, Rio de Janeiro, 2007, p. 371.

${ }^{438}$ BOBBIO, Norberto, Estado, Governo, Sociedade - Para uma teoria geral da política, $4^{\mathrm{a}}$ ed., Editora Paz e Terra, Rio de Janeiro, 2007, pp. 76/77.

${ }^{439}$ CRETELLA JR, José, Prerrogativas e Sujeições da Administração Pública, in Revista de Direito Administrativo, volume 103, Rio de Janeiro, janeiro a março de 1971, p. 17.

${ }^{440}$ FALZONE, Guido, Il dovere di buona ammnistrazione, Giufrè Editore, Milão, 1953, p. 37.

${ }^{441}$ JOUVENEL, Bertrand de, O Poder - História natural de seu crescimento, Ed. Peixoto Neto, São Paulo, 1998, p. 353.
} 
O poder, portanto, é atributo jurídico e político inseparável do Estado, através do qual ele se impõe fazendo prevalecer sua vontade, tornando possível a governabilidade e a imposição de um modelo de organização. ${ }^{442}$

No caso específico do poder de polícia, como vimos, ele se tornou cada vez mais presente e invasivo na sociedade contemporânea, colocando-se como instrumento indispensável ao desejado equilíbrio social.

Porém, há que se ponderar que num verdadeiro Estado de Direito este poder precisa encontrar limites que o mantenham dentro das fronteiras da legalidade. Num Estado Social de Direito, mais ainda, precisa circunscrever-se também dentro do campo da legitimidade, ou como na expressão forjada por Caio Tácito: “em seus domínios legitimos". 443

Certo é que os poderes da Administração devem ser exercidos de acordo com um sistema que há um tempo atribua-lhe condições de desempenho eficaz, sem descuidar da implantação de mecanismos de controle e fixação de limites. ${ }^{444}$

Neste sentido Carl Schimitt, em seu trabalho sobre a soberania do Estado já observava que:

"El Estado es poder originário de mandar, pero lo es en cuanto es fuerza de un orden, "forma" para la vida de un pueblo, no arbitrária coacción por medio de la violencia. Su intervención es requerida solo cuando la libre acción individual o corporativa sea insuficiente; debe quedarse en segundo plano como "ultima ratio". 445

De fato, o princípio da supremacia da ordem pública, com suporte no qual o poder da Administração é exercido, provém e está adstrito ao princípio da legalidade, sendo certo que este último exige que o poder seja praticado sempre com vistas ao interesse público. ${ }^{446}$

Não se tolera mais o exercício do poder sustentado exclusivamente pela força. A intuição de que há uma relação direta entre o poder e uma força que o

${ }^{442}$ CRUZ, Paulo Márcio, Política, Poder, Ideologia e Estado Contemporâneo, $2^{a}$ ed., Juruá, Curitiba, 2002, p. 52 .

${ }_{443}$ TÁCITO, Caio, Temas de Direito Público (Estudos e Pareceres), Renovar, Rio de Janeiro, 1997, p. 161.

${ }^{444}$ RIVERO, Jean, Curso de Direito Administrativo Comparado, Apostila, Tradução José Cretella Jr., Editora Revista dos Tribunais, São Paulo, 2004, p. 148.

${ }^{445}$ SCHIMITT, Carl, Teologia Política, Editorial Struhart e Cia, Cochabamba, 1998, p. 41.

${ }_{446}^{44}$ ARAÚJO, Edmir Netto de, Do Negócio Jurídico Administrativo, Ed. Revista dos Tribunais, São Paulo, 1.992, p. 79. 
sustenta há muito tem sido combatida por novas teorias sobre o poder, fundadas em mecanismos muito mais complexos. ${ }^{447}$

O poder é colocado, portanto, como instrumento do Estado para que este possa se desincumbir de modo eficiente de sua hercúlea tarefa de estabelecer e administrar os interesses sociais, na forma prevista pelo ordenamento jurídico. Em outras palavras, os poderes são atribuídos ao Estado para que ele possa cumprir a sua razão de ser. Nas palavras desmistificadoras de Diógenes Gasparini: "são, isto sim, meros instrumentos de trabalho". 448

\section{Conforme leciona Eros Grau ${ }^{449}$ :}

Os poderes que maneja a autoridade pública no desempenho da função administrativa são, destarte, poderes que detém exclusivamente a fim de que possa prestar acatamento ao vínculo que afeta sua vontade.

O poder de polícia, mais especificamente, consubstanciasse no exercício da autoridade com vistas a cumprir o seu dever de estabelecer o bem comum e a ordem pública. ${ }^{450}$

Tal objetivo, portanto, não pode servir de pretexto para o exercício abusivo do poder, pois o abuso do poder transforma o Estado em Estado autoritário. Se é verdade que o Estado jamais pode abrir mão do poder, tal conclusão não remete ao arbítrio que se configura pelo uso abusivo e desmedido dele. ${ }^{451}$

Também não há que se tolerar o desvio de poder, que José Cretella Junior $^{452}$ classifica com muita precisão como um distanciamento em relação ao espírito da lei, "numa aberratio finis legis".

Para melhor situar nossa exposição aqui, adotaremos a diferenciação trazida por Gasparini ${ }^{453}$ para quem o abuso de poder remete à execução do

${ }^{447}$ COELHO, Fábio Ulhoa, Direito e Poder, Editora Saraiva, São Paulo, 2010, pp. 37/38.

${ }^{448}$ GASPARINI, Diogenes, Direito Administrativo, $7^{\text {a }}$ ed., Saraiva, São Paulo, 2002, pp. 130 e seguintes.

${ }^{449}$ GRAU, Eros Roberto, Poder de Polícia: Função Administrativa e Princípio da Legalidade: O Chamado "Direito Alternativo", Revista Trimestral de Direito Público, n 01/1993, Editora Malheiros, p. 93.

${ }^{450}$ MAYER, Otto, Derecho Administrativo Alemán, Ed. Depalma, Buenos Aires, 1950, p. 19.

${ }^{451}$ PIRES, Luis Manuel Fonseca, Limitações Administrativas à Liberdade e à Propriedade, Quartier Latin, São Paulo, 2006, pp. 161/162.

${ }^{452}$ CRETELLA JR., José, Do Desvio de Poder, Editora RT, São Paulo, 1964, p. 12.

${ }^{453}$ GASPARINI, Diógenes, Direito Administrativo, $7^{a}$ ed., Saraiva, São Paulo, 2002, p. 133. 
ato, enquanto que o desvio de poder é defeito inerente ao ato em si, ou seja, é vício inerente à competência e/ou finalidade do ato.

Como vimos, no Estado de Direito, o poder de polícia tem como escopo tornar fruíveis os direitos e garantias individuais de modo equilibrado. Em outras palavras, ao estabelecer limites ao exercício destes direitos, o poder de polícia fixa a medida do razoável para seu exercício legítimo.

Neste sentido, conforme ministra Marçal Justen Filho:

Nenhuma atuação individual ou coletiva se legitima quando ultrapassa os limites da satisfação razoável dos interesses e se transforma em via de lesão ao próximo. ${ }^{454}$

Muito embora prevalente sobre o interesse particular, o poder de polícia, por óbvio, não é absoluto, encontrando limites na própria legislação e nos princípios consagrados para proteção do indivíduo. Assim como em outros casos, o "uso anormal" deste poder torna antijurídico o ato, maculando sua execução. ${ }^{455}$

Este é o nosso norte aqui. Ato de limitação de exercícios de direitos, praticado com abuso ou desvio de poder na verdade não pode ser considerado exercício do poder de polícia, degenerando-se em ato ilegal e injustificável juridicamente.

Conforme leciona Cretella $\mathrm{Jr}^{456}$, o poder de polícia está "longe de ser absoluto, onipotente, incontrolável”. Estes limites, em outras palavras, são as condições de validade formal-legal da atuação administrativa.

O mestre J. J. Canotilho ${ }^{457}$ já advertia que, especialmente ao restringir direitos, liberdades e garantias, a atuação do Estado: "deve ser adequada (apropriada), necessária (exigível) e proporcional (com justa medida).”

Com efeito, o poder de polícia não subsiste se maculado por condutas irrazoáveis, em que os fins perseguidos divergem das normas que as permitiram $^{458}$; desproporcionais, em que há um desequilíbrio entre o objeto e o meio

\footnotetext{
${ }^{454}$ JUSTEN FILHO, Marçal, Curso de Direito Administrativo, $3^{\mathrm{a}}$ edição, Saraiva, São Paulo, 2008, p. 462.

455 GASPARINI, Diógenes, Direito Administrativo, $7^{\mathrm{a}}$ ed., Saraiva, São Paulo, 2002, p. 131.

${ }^{456}$ CRETELLA JR., José, Direito Administrativo Brasileiro, Editora Forense, $2^{\text {a }}$ edição, Rio de Janeiro 2.000 , p. 550.

${ }^{457}$ CANOTILHO, JJ Gomes, Direito Constitucional e Teoria da Constituição, $4^{\text {a }}$ edição, Livraria Almedina, Coimbra, 1993, p. 447.

${ }^{458}$ Neste sentido, o Supremo Tribunal Federal no HC 79512-RJ decidiu pela prevalência do domicílio, assim considerado o escritório da empresa, frente ao poder de polícia, in verbis:, conforme trecho da ementa a seguir transcrito:
} 
empregado pela Administração e as que são praticas com excesso de limitação ou punição. $^{459}$

Não se pode perder de vista que, como espécie do gênero "atos administrativos", os atos de polícia para serem considerados válidos, precisam preencher os requisitos quanto à competência, a finalidade e a forma, a saber: competência fixada por lei, finalidade pública e forma prescrita e não vedada em lei, essenciais a validade do ato.

No que diz respeito especificamente à análise sobre a ocorrência de desvio ou abuso de poder de polícia, há que se sopesar de modo especial se o sacrifício exigido pela Administração do particular é proporcional ao benefício que advirá à sociedade, sendo certo que deverá haver uma ponderação a cerca da necessidade real da limitação ou condicionamento imposto, resguardando-se, em todos os casos os direitos subjetivos fundamentais. 460

$$
\text { Para a professora Maria Sylvia Zanella Di Pietro }{ }^{461} \text { esta }
$$

proporcionalidade deve ser perseguida:

...sob pena da 'via de direito' transformar-se em 'via de fato', gerando responsabilidade para o poder público e para o próprio servidor que se excedeu.

Tal preocupação com a proporcionalidade, que Canotilho ${ }^{462}$ denominava de "princípio da proibição do excesso", é exigência fundamental para a

"EMENTA: Prova: alegação de ilicitude da obtida mediante apreensão de documentos por agentes fiscais, em escritórios de empresa - compreendidos no alcance da garantia constitucional da inviolabilidade do domicílio - e de contaminação das provas daquela derivadas: tese substancialmente correta, prejudicada no caso, entretanto, pela ausência de qualquer prova de resistência dos acusados ou de seus prepostos ao ingresso dos fiscais nas dependências da empresa ou sequer de protesto imediato contra a diligência.

1. Conforme o art. $5^{\circ}, \mathrm{XI}$, da Constituição - afora as exceções nele taxativamente previstas ("em caso de flagrante delito ou desastre, ou para prestar socorro") só a "determinação judicial" autoriza, e durante o dia, a entrada de alguém - autoridade ou não - no domicílio de outrem, sem o consentimento do morador. 1.1. Em conseqüência, o poder fiscalizador da administração tributária perdeu, em favor do reforço da garantia constitucional do domicílio, a prerrogativa da autoexecutoriedade.

1.2. Daí não se extrai, de logo, a inconstitucionalidade superveniente ou a revogação dos preceitos infraconstitucionais de regimes precedentes que autorizam a agentes fiscais de tributos a proceder à busca domiciliar e à apreensão de papéis; essa legislação, contudo, que, sob a Carta precedente, continha em si a autorização à entrada forçada no domicílio do contribuinte, reduz-se, sob a Constituição vigente, a uma simples norma de competência para, uma vez no interior da dependência domiciliar, efetivar as diligências legalmente permitidas: o ingresso, porém, sempre que necessário vencer a oposição do morador, passou a depender de autorização judicial prévia. ...."

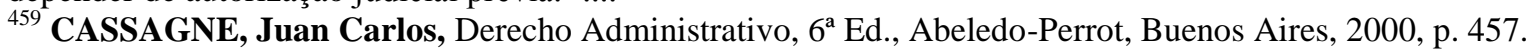

${ }^{460}$ ARAÚJO, Edmir Netto de, Curso de Direito Administrativo, Saraiva, 5a Ed., São Paulo, 2010, p. 1054.

${ }^{461}$ DI PIETRO, Maria Sylvia Zanella, Poder de Polícia, in Revista de Direito Público, São Paulo, v 24, ${ }^{\circ}$ 98, pg. 90-4, abr/jun. 1991, p. 91. 
prática dos atos de polícia, não bastando a presunção legal de que a autoridade age com a finalidade de evitar um mal e que, por isto, poderia exceder a medida adequada ao caso concreto. $^{463}$ A proporção entre a medida e a ofensa combatida, aliás, deve ser aferida a cada situação.

Não é suficiente, portanto, que o ato esteja amparado pela legalidade se na prática se mostrar desproporcional. ${ }^{464}$ A professora Dinorá Adelaide Grotti discorrendo sobre o tema enfatiza:

Vejam que a necessidade de meios coativos por parte da Administração é imposta em nome da defesa dos interesses públicos, mas como eu salientei inicialmente os poderes da Administração só devem ser utilizados se, quando e na medida indispensável para atingir aquela determinada finalidade. Ou seja, deve haver proporcionalidade entre a medida adotada e a finalidade a ser atingida. ${ }^{465}$

Não se justifica a limitação de um direito sem que tal limitação decorra de ato adequado, necessário e compatível com os valores constitucionais. A adequação pressupõe a correlação entre o meio utilizado e o fim perseguido ${ }^{466}$. A necessidade diz respeito à valoração quanto ao meio menos restritivo dentre os possíveis; e a compatibilidade expressa à atenção aos limites que a constituição impõe, no sentido de resguardar os direitos fundamentais de indevida supressão. ${ }^{467}$

A observância da real finalidade pública na prática do ato administrativo, de modo geral, é de tamanha importância que Cretella Junior chega a afirmar que:

A consignação do elemento fim como integrante do ato administrativo representa uma das mais notáveis conquistas do Direito Público

\footnotetext{
${ }^{462}$ CANOTILHO, JJ Gomes, Direito Constitucional e Teoria da Constituição, $4^{\mathrm{a}}$ edição, Livraria Almedina, Coimbra, 1993, p. 447.

${ }^{463}$ MAYER, Otto, Derecho Administrativo Alemán, Ed. Depalma, Buenos Aires, 1950, p. 31.

${ }^{464}$ FREITAS, Juarez, Poder de Polícia Administrativa - Novas Reflexões, BDA/Boletim de Direito Administrativo 6/657-668, Ed. Nova Dimensão, São Paulo, Junho de 2006. p. 657.

${ }^{465}$ GROTTI, Dinorá Adelaide Musetti, Poder de Polícia - Palestra proferida no Seminário nacional de Direito Administrativo - Edição Comemorativa dos 20 anos da NDI, BDS/Boletim de Direito Administrativo, 7/753-758, Ed. Nova Dimensão Jurídica, Junho 2006, p. 755.

${ }^{466}$ ÁVILA, Humberto, Teoria dos Princípios, da definição à aplicação dos princípios jurídicos, Editora Malheiros, $7^{\text {a }}$ ed., São Paulo, 2007, p. 163.

${ }^{467}$ JUSTEN FILHO, Marçal, Curso de Direito Administrativo, $3^{\text {a }}$ edição, Saraiva, São Paulo, 2008, p. 460.
} 
moderno, porque contribuiu de maneira eficaz para eliminar o conceito autoritário do governo. ${ }^{468}$

Bem por isto Cáio Tácito expressa que:

A finalidade, como assinalado, é elemento permanente de vinculação dos atos administrativos, e sua inobservância configura um vício peculiar - o desvio de poder ou finalidade. ${ }^{469}$

Fato é que as limitações que incidem sobre as liberdades são também tradução da conformação inerente aos direitos fundamentais. Tais limitações não têm outro fundamento que não seja a lei, conforme visto. Não há mais que se falar em poder de polícia embasado em um certo "poder geral implícito", inerente ao Estado na busca genérica pela "ordem pública" ou pelo "interesse público". 470

Não se justifica hodiernamente o exercício do poder de polícia lastreado tão somente em ideias abstratas como o "bem comum" ou "interesse público". Tais bens devem restar concretamente identificados e estar sob efetivo risco para que reste justificado o exercício do poder de polícia, sob pena de servir o instituto como instrumento a serviço de interesses antidemocráticos, tornando-se ilegal. ${ }^{471}$

Há que se ter em mente que quando o ente público deixa de observar as sujeições a que o poder de polícia está adstrito, deixa também de agir como órgão do Estado, fazendo transparecer a vontade do agente atuante, em flagrante desvio de poder. $^{472}$

Nem mesmo o denominado "princípio da eficiência", recentemente introduzido no artigo 37 da Constituição pela Emenda no 19/98, pode ser invocado para justificar a atuação do agente público fora dos limites legalmente estabelecidos. Neste sentido Humberto Ávila ministra que:

\footnotetext{
${ }^{468}$ CRETELLA JR., José, Do Desvio de Poder, Editora RT, São Paulo, 1964, p. 32.

${ }^{469}$ TÁCITO, Caio, Temas de Direito Público (Estudos e Pareceres), Renovar, Rio de Janeiro, 1997, p. 179.

${ }^{470}$ FIGUEIREDO, Lúcia Valle, Curso de Direito Administrativo, $9^{\mathrm{a}}$ edição, Malheiros, São Paulo, 2008, p. 284.

471 JUSTEN FILHO, Marçal, Curso de Direito Administrativo, $3^{\mathrm{a}}$ edição, Saraiva, São Paulo, 2008, p. 460.

472 CRETELLA JR, José, Prerrogativas e Sujeições da Administração Pública, in Revista de Direito Administrativo, volume 103, Rio de Janeiro, janeiro a março de 1971, p. 21.
} 
A realização de uma regra ou princípio constitucional não pode conduzir à restrição a um direito fundamental que lhe retire um mínimo de eficácia.”

... o grau de importância da promoção do fim justifica o grau de restrição causada aos direitos fundamentais. ${ }^{473}$

Se por um lado, como vimos, para poder exercer com eficiência seus poderes a Administração conta com os atributos da autoexecutoriedade e da coerção, é certo que tais atributos encontram limites, tanto na lei quanto na finalidade pública que pretendem alcançar. Os meios de coação, por atingirem de modo cada vez mais incisivo a liberdade e os direitos do administrado precisam ser empreendidos de forma comedida, sempre com vistas ao objetivo que a lei colimou, sendo certo que qualquer desvio ou excesso acarretarão a responsabilização da Administração e do agente que se portou de modo ilegal ou desproporcional.

Vale frisar, os meios aplicados pela administração não podem ser mais intensos do que o necessário, nem mais extensos do que o oportuno para a busca do bem legalmente tutelado. ${ }^{474}$

É oportuna a observação de Fábio Ulhoa Coelho para quem:

O poder é da essência de todo governo, ao passo que a violência tem natureza exclusivamente instrumental, necessitando por este motivo orientação e justificação. O poder não precisa ser justificado, uma vez que existe onde houver comunidade política. Ele necessita de legitimação, atributo diversa da justificação. ${ }^{475}$

Oportuno aqui lembrar a lição de Otto Mayer que em linguagem figurada retratou com precisão o fato de que, ao combater uma perturbação da ordem, o

\footnotetext{
473 ÁVILA, Humberto, Teoria dos Princípios, da definição à aplicação dos princípios jurídicos, Editora Malheiros, $7^{\text {a }}$ ed., São Paulo, 2007, p. 173.

${ }^{474}$ BANDEIRA DE MELLO, Celso Antônio, Curso de Direito Administrativo, Malheiros, $21^{\text {a }}$ ed., São Paulo, 2006, p. 801.

${ }^{475}$ COELHO, Fábio Ulhoa, Direito e Poder, Editora Saraiva, São Paulo, 2010, p. 52.
} 
Estado não pode suprimir um direito legítimo: “arrancando así la planta com las mazelas" "476

Lançando mão de outra lição clássica, lembramos as palavras de Anníbal Martins Alonso que chama a atenção para o fato de que:

O simples e inoportuno arbítrio sob o disfarce de poder de polícia, pode resultar em opressão ou tirania. ${ }^{477}$

Cumpre ainda ressalvar que há desvios de poder que não são tão evidentes, mas que igualmente, maculam o exercício do poder de polícia. Bem por isto a execução de atos de polícia devem obedecer a delimitações precisas, sendo vedada a delegação genérica, sem contornos claros. ${ }^{478}$

O fim estabelecido por lei é o limite para o exercício do poder de polícia, sendo certo que, ao ultrapassar os fins colimados pela norma, o Poder Público macula o ato com o vício do desvio de poder. ${ }^{479}$

Conforme muito bem observado por Antônio Carlos Cintra do Amaral:

...dizer-se que a Administração está autorizada a praticar atos ilegais, desde que isso contribua para aumentar sua eficiência, é no mínimo tão absurdo quanto dizer-se que uma empresa privada pode praticar atos ilícitos desde que isso contribua para aumentar sua eficiência. ${ }^{480}$

Mudando o enfoque, é oportuno destacar que é pacífico o entendimento de que ao exercer seus poderes o Estado não pode se utilizar de meios vexatórios, violentos, abusivos, jamais sendo tolerável a supressão ilegal dos direitos individuais. $^{481}$

A inobservância destes parâmetros, por certo, caracteriza abuso de poder. Juarez Freitas resume a questão ao afirmar que:

\footnotetext{
${ }^{476}$ MAYER, Otto, Derecho Administrativo Alemán, Ed. Depalma, Buenos Aires, 1950, p. 32.

${ }^{477}$ ALONSO, Anníbal Martins, Poder de Polícia, Polícia Administrativa, Polícia Judiciária, 1954, p. 06.

${ }^{478}$ PIRES, Luis Manuel Fonseca, Limitações Administrativas à Liberdade e à Propriedade, Quartier Latin, São Paulo, 2006, p. 255.

${ }^{479}$ CRETELLA JR., José, Do Desvio de Poder, Editora RT, São Paulo, 1964, p. 43.

480 AMARAL, Antônio Carlos Cintra, O Princípio da Eficiência no Direito Administrativo, in Revista Eletrônica sobre a Reforma do Estado, ${ }^{\circ}$ 05, março/maio, Salvador, 2006, p. 06.

${ }^{481}$ ARAÚJO, Edmir Netto de, Curso de Direito Administrativo, Saraiva, 5a ed., São Paulo, 2010, p. 1055.
} 
...o exercício do "poder de polícia administrativa" há de ser digno e gerador de dignidade, ou será irregular e abusivo. ${ }^{482}$

Há que se registrar que até mesmo a omissão do Poder Público pode caracterizar desvio de poder. Este sutil modo de abuso pode ocorrer nos casos em que o particular necessita da manifestação ou autorização do Poder Público para prática de algum ato e este, sem justificativa se omite. ${ }^{483}$

Também podemos imaginar a hipótese do fiscal que diante de uma situação de flagrante desrespeito à lei (de trânsito ou de posturas municipais) se omite de aplicar uma multa para favorecer o infrator, para obter vantagem própria ou para proteger indevidamente a terceiro.

Por fim vale anotar que os condicionamentos que se encontram no âmbito do poder de polícia não devem ser confundidos com os sacrifícios de direitos. Os primeiros (condicionamentos impostos pelo poder de polícia) visam impor limites ao exercício dos direitos individuais e, portanto, agem no sentido de mantê-los. Já os sacrifícios a direitos exigem um procedimento diferenciado para se perpetrarem. Não basta a previsão legal. Para que a Administração possa impor sacrifícios a direitos particulares é necessária a autorização judicial, após o devido processo, sendo exigida também a justa e prévia indenização. ${ }^{484}$ Fora deste padrão, por certo restará caracterizado o abuso ou o desvio de poder. ${ }^{485}$

\section{V.5 - O Poder de Polícia num Ambiente de Democracia Participativa/Deliberativa}

Colocadas as balizas que norteiam o poder de polícia no direito contemporâneo e constatado que hodiernamente não se compreende o exercício desta função estatal a não ser nos estritos lindes da legalidade e a serviço da sociedade, detentora da soberania e razão última de qualquer expressão de poder, passaremos a analisar um dos vieses mais interessantes pelos quais esta soberania popular pode se manifestar, em

${ }^{482}$ FREITAS, Juarez, Poder de Polícia Administrativa - Novas Reflexões, BDA/Boletim de Direito Administrativo 6/657-668, Ed. Nova Dimensão, São Paulo, Junho de 2006, p. 658.

${ }_{483}$ BANDEIRA DE MELLO, Celso Antônio, Grandes Temas de Direito Administrativo, Malheiros, São Paulo, 2009, p. 134.

${ }^{484}$ SUNDFELD, Carlos Ari, Direito Administrativo Ordenador, Malheiros Editores, São Paulo, 2003, p. 86.

${ }^{485}$ SUNDFELD, Carlos Ari, Direito Administrativo Ordenador, Malheiros Editores, São Paulo, 2003, pp. $67 / 68$. 
particular, legitimando a construção e prática dos atos de polícia administrativa: a participação popular.

A participação popular na base da atuação da Administração Pública é uma das expressões mais evidentes da implementação do Estado Social e Democrático de Direito.

A ênfase a utilização da expressão "participação popular" é importante como fator de fixação da natureza realmente democrática que aspira a sociedade. Segundo Maria Sylvia Zanella Di Pietro:

A expressão "participação popular" parece a mais oportuna, no momento presente, por ser inerente ao princípio democrático em que se inspira o Estado de Direito sob a forma adotada a partir do preâmbulo da Constituição de 1988: Estado Democrático de Direito. ${ }^{486}$

A participação dos indivíduos na elaboração e implementação das decisões coletivas é, sem duvida, verdadeiro requisito da democracia, num ambiente em que cada membro tenha oportunidade de fazer a diferença, ${ }^{487}$

Esta almejada forma de experimentar a democracia traduz a superação do sistema em que o voto formal era a única tradução do consentimento popular. Nas palavras de Moreira Neto:

...trata-se de buscar um consenso mais amplo sobre a escolha de políticas públicas através de outras formas institucionais que possam disciplinar com fidelidade e segurança o processo de formação da vontade participativa, ou seja, a crescente importância da processualidade adequada como instrumento democrático. ${ }^{488}$

Um dos defensores desta nova visão de Estado Democrático, Jürgen Habermas explica, com fundamento na teoria desenvolvida por Hegel, que a

\footnotetext{
${ }^{486}$ DI PIETRO, Maria Sylvia Zanella, Participação Popular na Administração Pública, in Revista de Direito Administrativo, nº 191, p 26-39 - Janeiro a março de 1993, p. 26.

${ }^{487}$ MENDES, Conrado Hübner, Controle de Constitucionalidade e Democracia, Campus Jurídico, Rio de Janeiro, 2008, p. 66.

${ }^{488}$ MOREIRA NETO, Diogo de Figueiredo, Novas Tendências da Democracia: Consenso e Direito Público na Virada do Século - O Caso Brasileiro, in Revista Eletrônica sobre a Reforma do Estado, $\mathrm{n}^{\circ}$ 13, março/abril/maio de 2008, Salvador, p. 02.
} 
evolução experimentada nos últimos tempos deu causa a um verdadeiro "espírito objetivo" da sociedade. Para o autor:

...a sociedade encontra sua unidade na vida pública e na organização do Estado, a filosofia prática da modernidade parte da ideia de que os indivíduos pertencem à sociedade como os membros a uma coletividade ou como as partes a um todo que se constrói através da ligação de suas partes. $^{489}$

Em razão deste "espírito objetivo" não se concebe mais a ideia de um Estado que se expressa de modo arbitrário, sem refletir a vontade de seus cidadãos, pois na democracia contemporânea o indivíduo, como membro efetivo da sociedade, não pode ser considerado mero coadjuvante.

Bem ao encontro deste entendimento a Constituição Federal de 1988 estabeleceu de forma inequívoca a participação direta do cidadão como um dos mecanismos para a realização da democracia ${ }^{490}$, como podemos verificar no artigo $74, \S 2^{\circ}$ e no artigo $31, \S 3^{\circ}$, por exemplo. ${ }^{491}$

De fato, sem a efetiva e qualificada participação popular na órbita pública e nas decisões relevantes do Estado, não há se falar em democracia. Com efeito, podemos afirmar que o desenvolvimento de uma sociedade pode ser medido pela capacidade de seus membros de apreender, articular e participar das questões e decisões práticas e teóricas que lhe são caras. ${ }^{492}$

Paulo Bonavides, contundente, assevera que na verdade:

Não há democracia sem participação. De sorte que a participação aponta para as forças sociais que vitalizam a democracia e lhe assinam o grau de eficácia e legitimidade no quadro social das relações de poder, bem como

\footnotetext{
${ }^{489}$ HABERMAS, Jürgen, Direito e Democracia - entre a facticidade e validade - vol. I, Biblioteca Tempo Brasileiro, Rio de Janeiro, 2.010, p. 17.

${ }^{490}$ FIGUEIREDO, Lúcia Valle. Instrumentos da Administração Consensual: A Audiência Pública e sua Finalidade, in Revista Eletrônica de Direito Administrativo Econômico, no 11, agosto/outubro de 2007, Salvador, p. 01.

${ }^{491}$ No mesmo sentido: OLIVEIRA, Gustavo Henrique Justino de, Participação Administrativa, in Revista Eletrônica sobre a Reforma do Estado, nº 03, setembro/novembro de 2005, Salvador para quem; "não é possível deixar de notar que o Texto Constitucional Pátrio, em diversos momentos, pautou um caminho para maior participação dos cidadãos na esfera administrativa."

492 HABERMAS, Jürgen, A Crise de Legitimidade no Capitalismo Tardio, Edições Tempo Brasileiro, Rio de Janeiro, 1999, p. 20.
} 
a extensão e abrangência desse fenômeno político numa sociedade repartida em classes ou em distintas esferas e categorias de interesses. ${ }^{493}$

Com efeito, numa sociedade onde não são trabalhados os mecanismos de participação qualificada dos indivíduos nos processos de decisões das questões relevantes da comunidade ou do país, não há desenvolvimento democrático.

Na precisa lição de Robert Dahl:

A melhor razão para se aprimorar nossa capacidade de análise política é o fato de que esta análise nos ajuda a compreender o mundo em que vivemos, a fazer escolhas mais inteligentes entre as alternativas que enfrentamos, a influenciar as transformações inerentes a todo sistema político. ${ }^{494}$

A este mecanismo Habermas ${ }^{495}$ houve por bem denominar de "razão comunicativa", através da qual, por meio da transmissão racional do argumento o indivíduo busca no outro o reconhecimento de sua pretensão e com isto a sua validade: "revelando a disposição de aceitar obrigatoriedades relevantes para as consequências da interação e que resultam de um consenso."

Há, portanto, na democracia participativa um aspecto psicológico patente. Nas palavras de Montoro:

O sentimento de participação é um dos poderosos elementos propulsores da atividade humana. ${ }^{496}$

Mas este almejado alto grau de atividade democrática, conforme se sabe, tem sido perseguido por longo, espinhoso e complexo caminho, restando ainda muito dele a ser percorrido. Neste aspecto, o desenrolar dos acontecimentos do século XX foi

\footnotetext{
${ }^{493}$ BONAVIDES, Paulo, Teoria Constitucional da Democracia Participativa, Malheiros Editores, $3^{\text {a }}$ ed., São Paulo, 2008, p. 51.

${ }^{494}$ DAHL, Robert Alan, Análise Política Moderna, Ed. Universidade de Brasília, Brasília, 1981, p. 13.

${ }^{495}$ HABERMAS, Jürgen, Direito e Democracia - entre a facticidade e validade - vol. I, Biblioteca Tempo Brasileiro, Rio de Janeiro, 2.010, p. 20.

${ }^{496}$ MONTORO, Franco, Da Democracia que Temos para a Democracia que Queremos, Ed. Paz e Terra, Rio de Janeiro, 1974, p. 44.
} 
especialmente marcado pela dialética em torno da democracia, tendo sido colocado em discussão até mesmo a sua desejabilidade que, a final, restou praticamente inconteste. ${ }^{497}$

No decorrer deste trabalho pudemos constatar como as transformações sociais e a evolução histórica conduziram as civilizações ocidentais, de um modo geral, a um sistema político-econômico-jurídico em que os direitos e garantias individuais alçaram a um patamar de grau máximo de proteção.

Neste cenário, não tinha mais lugar um Estado autoritário, que intervinha de modo desmedido no âmbito particular, fundamentado exclusivamente num fluido conceito de "interesse público". Por outro lado, rapidamente se deu conta de que mesmo sendo precioso, o exercício dos direitos individuais precisava encontrar limites claros, sob pena de se instalar uma crise social em que seus membros, através da força, procurariam impor cada um a sua própria razão em detrimento dos demais atores sociais e em prejuízo de todo o sistema.

Em razão do excessivo individualismo, o liberalismo econômico implementado a partir do século XVIII demonstrou não ser capaz de proporcionar condições aceitáveis de vida a todas as pessoas, mostrando-se incapaz de atender as complexidades da vida em uma sociedade desigual.

Em razão desta constatação, o Estado passou a agir como "tutor da sociedade", na intenção de produzir algum equilíbrio social e alcançar alguma igualdade, fazendo surgir o "Estado Providência". No entanto, ao invés de gerar igualdade e liberdade, novamente a concentração de poderes na figura do Estado e dos governantes propiciou o surgimento de governos autoritários que acabaram por sufocar os direitos individuais ao invés de garanti-los.

A crise neste modelo, que o professor Gustavo Henrique Justino de Oliveira ${ }^{498}$ denomina de "providencialista", impôs uma reformulação dos conceitos e do modo de agir do Poder Público.

Como reação a este "Estado tutelante" e autoritário, foi surgindo um "Estado parceiro", que passa a atuar como instrumento para o atingimento dos ideais democráticos. 499

\footnotetext{
${ }^{497}$ SANTOS, Boaventura de Souza (org.). Democratizar a democracia: os caminhos da democracia participativa. Rio de Janeiro; Civilização Brasileira, 2002, p. 39.

${ }_{498}$ OLIVEIRA, Gustavo Henrique Justino de, Participação Administrativa, in Revista Eletrônica sobre a Reforma do Estado, $\mathrm{n}^{\circ}$ 03, setembro/novembro de 2005, Salvador, p. 01.

${ }^{499}$ MOREIRA NETO, Diogo de Figueiredo, Quatro Paradigmas do Direito Administrativo Pós-Moderno, Ed. Forense, Rio de Janeiro, 2008, pp. 21/23.
} 
O caráter arbitrário da noção de interesse público, surgido no Absolutismo e fortalecido de certa forma no Liberalismo, cedeu diante do surgimento do denominado "Estado Pluriclasse" 500 , em que o Estado passou a exercer funções definidas de maneira mais democrática, ganhando força a ideia de "finalidades coletivas justificadoras ${ }^{, 501}$.

Tal mudança ganhou força notadamente no final do século XX como resultado dos conflitos ideológicos nos quais os marxistas marcavam posição acreditando que a solução para a desproporção entre as classes não seria resolvida a não ser pela descaracterização total da democracia como forma de governo. Por sua vez, a concepção hegemônica de democracia apresentada especialmente por Joseph Schumpter e Norberto Bobbio, numa releitura da doutrina Kelsiana, também não trouxe respostas adequadas para questionamentos importantes tais como: o elevado índice de abstencionismo, a "patologia da representação" e a incapacidade das burocracias de enfrentar os problemas sociais e ambientais mais complexos.

Tais elementos, somados aos embates ideológicos e ao contexto social forçaram à idealização de meios alternativos ao modelo liberal clássico e a rediscussão da própria democracia, dando ensejo a denominada democracia participativa. $^{502}$

Nas palavras de Raphael Augusto Sofiati de Queiroz:

Da ênfase aos princípios da executoriedade e ao caráter imperativo dos atos administrativos busca-se, nesta nova fase, a consensualidade. A Administração pública subordinativa, unilateral, hierarquizada e linear, deve ceder espaço à administração pública coordenativa, multilateral, equiordinada e radial, em plena expansão. ${ }^{503}$

Eis aqui o ponto de convergência. Todas as transformações sociais e no Estado que temos tratado conduzem para a esta nova forma de expressão da

\footnotetext{
${ }^{500}$ DI PIETRO, Maria Sylvia Zanella, Participação Popular na Administração Pública, in Revista de Direito Administrativo, $\mathrm{n}^{\circ}$ 191, p 26-39 - janeiro a março de 1993, pp. 30/31.

${ }^{501}$ MARQUES NETO, Floriano Peixoto de Azevedo, Regulação Estatal e Interesses Públicos, Malheiros, São Paulo, 2002, p. 89.

502 SANTOS, Boaventura de Souza (org.). Democratizar a Democracia: os caminhos da democracia participativa. Rio de Janeiro; Civilização Brasileira, 2002, pp. 40/48.

503 QUEIROZ, Raphael Augusto Sofiati de, Direito Público \& Segurança Pública - Ensaios e Pareceres, Editora Lumen Juris, Rio de Janeiro, 2001, p. 45.
} 
democracia e a um novo modelo de exercício do poder de polícia, que se coadune a este Estado contemporâneo, que caminha para uma democracia cada vez mais participativa.

Nas precisas palavras de Franco Montoro, a democracia participativa:

É a substituição do paternalismo governamental pela participação ativa das comunidades.

É o cultivo da solidariedade social, como forma de combate a todas as modalidades de exploração e opressão. ${ }^{504}$

O Estado Democrático contemporâneo parte, portanto, do pressuposto de que o Poder se coloca como ferramenta para obtenção de um ambiente social saudável e equilibrado. Neste ambiente, por óbvio, torna-se premente uma participação popular qualificada nas tomadas de decisões relevantes, em especial nas decisões que dizem respeito às limitações a serem impostas às liberdades e incidentes sobre o exercício dos direitos - o poder de polícia.

Isto porque esta participação qualificada e decisiva é que legitima a atuação Estatal. Torna-se imperioso, pois, que o sistema de socialização seja capaz de formar indivíduos capazes de falar e agir ${ }^{505}$, expressando seus anseios e defendendo seus interesses para que, muito embora altamente indispensável, o poder de polícia possa encontrar limites na lei e equilíbrio e legitimidade na vontade soberana do povo.

Este almejado ambiente, por certo, favorece o desenvolvimento pelo cidadão da denominada persuasão racional, através da qual, pela transmissão da informação o indivíduo, de modo eficaz, pode decidir o melhor para si e para sua comunidade.

Tal dinâmica, por certo, alinhasse com os pilares fundamentais da democracia participativa: o princípio da dignidade da pessoa humana e o princípio da soberania popular. ${ }^{506}$

\footnotetext{
${ }^{504}$ MONTORO, Franco, Alternativa Comunitária, um caminho para o Brasil, Ed. Nova Fronteira, Rio de Janeiro, 1982, p. 09.

${ }^{505}$ HABERMAS, Jürgen, A Crise de Legitimidade no Capitalismo Tardio, Edições Tempo Brasileiro, Rio de Janeiro, 1999, p. 21.

${ }^{506}$ BONAVIDES, Paulo, Teoria Constitucional da Democracia Participativa, Malheiros Editores, $3^{\text {a }}$ ed., São Paulo, 2008, p. 10.
} 
Robert Dahl, remetendo a ideia de república expressada por Rousseau (onde os indivíduos se submeteriam às leis por eles mesmos escolhidas) transmite com precisão este conceito:

Os cidadãos se empenham num processo de persuasão racional mútua, aceitando livremente as obrigações criadas pelas decisões coletivas, após deliberação ${ }^{507}$

Segundo Habermas, esta teoria contemporânea do direito e da democracia:

...toma como ponto de partida a força social integradora de processos de entendimento não violentos, racionalmente motivadores, capazes de salvaguardar distâncias e diferenças reconhecidas, na base da manutenção de uma comunhão de convicções. ${ }^{508}$

\section{Para Montoro:}

Adotar processos comunitários significa empregar métodos de ação social com a participação ativa dos membros da comunidade. Significa ver em cada homem um ser capaz de agir de forma racional e responsável, e não simples "objeto" a receber passivamente benefícios e atenções. Significa substituir o paternalismo pela participação. ${ }^{509}$

A postura exigida pela democracia participativa, exercida o quanto possível através de processos de persuasão racional, tenta pois enfrentar dois problemas cruciais dos modelos representativos clássicos da razão prática, quais sejam: a perda de identificação entre os representados e os representantes, especialmente no caso das minorias e a falência do sistema de prestação de contas (cumprimento das finalidades

${ }^{507}$ DAHL, Robert Alan, Análise Política Moderna, Ed. Universidade de Brasília, Brasília, 1981, p. 42.

${ }^{508}$ HABERMAS, Jürgen, Direito e Democracia - entre a facticidade e validade - vol. I, Biblioteca Tempo Brasileiro, Rio de Janeiro, 2.010, p. 22.

${ }^{509}$ MONTORO, Franco, Alternativa Comunitária, um caminho para o Brasil, Ed. Nova Fronteira, Rio de Janeiro, 1982, p. 22. 
públicas dos atos administrativos) causado pelo distanciamento entre eleitos e os cidadãos representados. $^{510}$

A democracia deliberativa traz respostas a estas questões na medida em que:

A produção de direito legítimo através de uma política deliberativa configura, pois, um processo destinado a solucionar problemas, o qual trabalha com saber, ao mesmo tempo em que o elabora, a fim de programar a regulação de conflitos e a persecução de fins coletivos ${ }^{511}$

Conforme afirma Conrado Hübner Mendes, analisando a visão de democracia proposta por Ronald Dworkin:

Numa democracia genuína, as pessoas governam não estatisticamente (majoritariamente), mas comunalmente. Elas tratam a nação como uma unidade coletiva de responsabilidade. Compartilham a responsabilidade por cada ato de governo. ${ }^{512}$

A participação popular no Estado contemporâneo é, portanto, elemento posto como indispensável ao estabelecimento de uma correta governança, que conduz ao ambiente social desejável. Bem por isto, a professora Maria Sylvia consigna na obra já mencionada que:

É neste sentido que a participação popular é uma característica essencial do Estado Direito Democrático, porque ela aproxima mais o particular da Administração, diminuindo ainda mais as barreiras entre o Estado e a sociedade. $^{513}$

\footnotetext{
510 SANTOS, Boaventura de Souza (org.). Democratizar a Democracia: os caminhos da democracia participativa. Rio de Janeiro; Civilização Brasileira, 2002, pp. 49/50.

${ }_{511}$ HABERMAS, Jürgen, Direito e Democracia - entre a facticidade e validade - vol. II, Biblioteca Tempo Brasileiro, Rio de Janeiro, 2.010, p. 45.

${ }_{512}$ MENDES, Conrado Hübner, Controle de Constitucionalidade e Democracia, Campus Jurídico, Rio de Janeiro, 2008, p. 66.

${ }^{513}$ DI PIETRO, Maria Sylvia Zanella, Participação Popular na Administração Pública, in Revista de Direito Administrativo, nº 191, p 26-39 - janeiro a março de 1993, p. 32.
} 
Para o atingimento deste ambiente de efetiva participação popular, a democracia deliberativa, tem como cerne o respeito essencial à legitimidade dos mecanismos democráticos e aos meios imparciais de deliberação. ${ }^{514}$

Só é concebida como válida, a atuação que é reconhecida pelo grupo que irá sofrer sua incidência, como produto de um processo deliberativo onde houve efetiva participação do cidadão; num contexto em que puderam ocorrer discussões e debates entre os interessados.

No contexto da Democracia contemporânea (pós-moderna), passou-se a compreender que a legalidade isoladamente não é capaz de dar respostas a altura das graves demandas da sociedade e que, sem legitimidade, as Constituições e os corpos normativos dos Estados não passam de declarações formalistas impostas à força. ${ }^{515}$

Não estamos aqui propondo uma visão ingênua do cenário político. Conforme ressalva Dahl ${ }^{516}$ :

... a persuasão manipulativa, o poder, a coerção, a ameaça e o emprego da força física são aspectos comuns da vida política.

Não obstante, é seguro afirmar que a sociedade moderna não tolera mais o exercício do poder Estatal imposto de forma arbitrária. A Democracia, para se sustentar em níveis aceitáveis, precisou desenvolver mecanismos pelos quais o exercício de poder seja correspondente às expectativas dos titulares do poder, ou seja, o povo.

Nas palavras do professor Boaventura de Souza Santos:

Trata-se de negar as concepções substanciais de razão e as formas homogeneizadoras de organização da sociedade, reconhecendo a pluralidade humana. ${ }^{517}$

\footnotetext{
${ }^{514}$ NOBRE, Marcos, in Participação e Deliberação na Teoria Democrática - Uma introdução; texto integrante da obra: Participação e Deliberação - Teoria Democrática e Experiências Institucionais no Brasil Contemporâneo, COELHO, Vera Schattan P., e NOBRE, Marcos (org.), Editora 34, São Paulo, 2004, p. 34.

${ }^{515}$ MOREIRA NETO, Diogo de Figueiredo, Quatro Paradigmas do Direito Administrativo Pós-Moderno, Ed. Forense, Rio de Janeiro, 2008, p 23.

${ }_{517}^{5}$ DAHL, Robert Alan, Análise Política Moderna, Ed. Universidade de Brasília, Brasília, 1981, p. 42.

517 SANTOS, Boaventura de Souza (org.). Democratizar a Democracia: os caminhos da democracia participativa. Rio de Janeiro; Civilização Brasileira, 2002, p. 51.
} 
Bem por isto o professor Gustavo Henrique Justino de Oliveira afirma de forma categórica que, não obstante as opiniões contrárias:

... entende-se que mais do que uma tendência da Administração pública contemporânea, a participação administrativa é uma realidade e há de ser entronizada no corpo administrativo do Estado. ${ }^{518}$

Com a mesma perspicácia, o professor Floriano de Azevedo Marques, após uma apresentação precisa a respeito da complexidade do Estado contemporâneo, se posiciona esclarecendo que:

...a tendência será, dentro da perspectiva de um Estado Democrático de Direito, dotar a sociedade dos meios de participação plena no processo decisório e permitir que a aferição do interesse público possa ser fruto de um processo contínuo de cotejamento dos valores ou princípios que se embatem na situação concreta e no qual o Estado seja, a um só tempo, mediador de interesses sociais relevantes e colidentes mas também exerça um papel de implementador de interesses meta-individuais hipossuficientes no jogo social. ${ }^{519}$

Com efeito, é este processo de legitimação que faz com que as imposições do Estado - a saber, o exercício do poder de polícia - se tornem minimamente toleráveis, pois correspondem em certa medida ao exercício de poder que os cidadãos esperam que o Estado exerça, justamente para que o convívio social seja o mais saudável possível.

Nas palavras de Habermas:

Tanto quanto temos que lidar com a forma de socialização que conecta nossa natureza interna numa organização comunicativa de comportamento, é inconcebível que houvesse legitimação de qualquer norma de ação que, mesmo aproximadamente, garanta uma aceitação de decisões sem motivos. A motivação para a disposição de conformar-se a um poder decisório, ainda indeterminado em conteúdo, é a expectativa

${ }^{518}$ OLIVEIRA, Gustavo Henrique Justino de, Participação Administrativa, in Revista Eletrônica sobre a Reforma do Estado, $n^{\circ}$ 03, setembro/novembro de 2005, Salvador, p. 20.

${ }^{519}$ MARQUES NETO, Floriano Peixoto de Azevedo, Regulação Estatal e Interesses Públicos, Malheiros, São Paulo, 2002, p. 147. 
que este poder será exercitado de acordo com as normas legítimas de ação. A motivação, em última instância, para a disposição de obedecer é a convicção do cidadão de que ele poderia ser discursivamente convencido no caso de dúvidas. ${ }^{520}$

É neste cenário, em que o poder é elemento inerente a vontade do povo e é conferido ao Estado para exercê-lo de forma legítima, que se constrói a idéia do exercício do poder de polícia no contexto de uma democracia deliberativa/participativa.

Conforme já advertência Bobbio:

O debate sobre os critérios de legitimidade não tem apenas um valor doutrinal; ao problema de legitimidade está estreitamente ligado o problema da obrigação política, à base do princípio de que a obediência é devida apenas ao comando do poder legítimo. ${ }^{521}$

Por sua vez Habermas argumenta que:

... o processo legislativo democrático precisa confrontar seus participantes com as expectativas normativas das orientações do bem da comunidade, porque ele próprio tem que extrair sua força legitimadora do processo de um entendimento dos cidadãos sobre regras de sua conveniência.

Fábio Ulhoa Coelho pondera sobre este ponto com especial profundidade e clareza:

Mesmo no interior de uma elaboração naturalista, a questão da correspondência entre a vontade expressa em normas e a natureza ética do agir humano está relacionada apenas com a legitimidade do conteúdo normatizado e não com sua origem. ${ }^{522}$

\footnotetext{
${ }^{520}$ HABERMAS, Jürgen, Direito e Democracia - entre a facticidade e validade - vol. I, Biblioteca Tempo Brasileiro, Rio de Janeiro, 2.010, p. 60.

${ }^{521}$ BOBBIO, Norberto, Estado, Governo, Sociedade - Para uma teoria geral da política, $4^{\mathrm{a}}$ ed., Editora Paz e Terra, Rio de Janeiro, 2007, p. 91.

${ }^{222}$ COELHO, Fábio Ulhoa, Direito e Poder, Editora Saraiva, São Paulo, 2010, p. 01.
} 
Em suma, somente a participação efetiva e racional dos mais variados atores da sociedade na discussão e deliberação dos temas relevantes é que qualifica (legitima) como plural a democracia e legítimo o exercício do poder, em especial o de policia administrativa.

Notoriamente nos casos em que estão em jogo justamente as liberdades individuais e o exercício dos direitos, os mecanismos de participação e deliberação para o alcance de normas aceitáveis e coerentes sobre o uso do poder de polícia se mostram imprescindíveis.

Para que a função de polícia seja exercida efetivamente a serviço da comunidade, correspondendo a atitude esperada pelos indivíduos mesmo em casos extremos, em que o uso da força se mostre imprescindível (v.g. desocupação de moradia em área de risco iminente, localizadas em encostas que ameaçam a vir abaixo, etc.), são imprescindíveis os mecanismos de participação popular que conduzam a uma deliberação racional sobre tais questões, ou seja, deve ser garantida "uma forma de exercício coletivo do poder político". 523

Vale neste ponto ponderar que várias são as abordagens modernas sobre a deliberação e participação no Estado Democrático de Direito, sendo fundamental o correto entendimento do tema, motivo pelo qual nos aprofundaremos um pouco mais.

Se a democracia é a forma de governo em que o cidadão participa de modo mais efetivo, é preciso ter claro quem são os cidadãos e de que modo esta participação se realiza.

$\mathrm{Na}$ ideia de democracia está implícita a da participação dos cidadãos nas tomadas de decisões a que serão submetidos. A democracia se legitima por meio da participação livre dos indivíduos que serão afetados pelas decisões e normas estatais. O regime democrático se notabiliza pela efetiva participação do maior número possível de indivíduos capazes, sem discriminação nas deliberações: "Democracia e participação são conceitos entrelaçados. " 524 ,

No entanto, a legitimidade não pode estar vinculada com a “contagem de cabeças" ${ }^{525}$. Na verdade a democracia pós-moderna se caracteriza pela

523 SANTOS, Boaventura de Souza (org.). Democratizar a democracia: os caminhos da democracia participativa. Rio de Janeiro; Civilização Brasileira, 2002, pp. 52/53.

${ }^{524}$ UGARTE, Pedro Salazar, in Que participação, para qual democracia? Texto integrante da obra: Participação e Deliberação - Teoria Democrática e Experiências Institucionais no Brasil Contemporâneo, COELHO, Vera Schattan P., e NOBRE, Marcos (org.), Editora 34, São Paulo, 2004, pp. 93/95.

${ }^{525}$ DRYZEK, John S., in, Legitimidade e Economia na Democracia Deliberativa. Texto integrante da obra: Participação e Deliberação - Teoria Democrática e Experiências Institucionais no Brasil Contemporâneo, 
possibilidade que abre a permanente discussão sobre os fundamentos da vida em comum. Ela é marcada fortemente pela constante discussão sobre os relacionamentos interpessoais, onde são expostas as divergências e conflitos morais e de interesses que devem ser resolvidos por meio de instrumentos adequados.

Assim sendo, a questão sobre a ampliação dos meios de reflexão social, de negociação e de deliberação dos vários interesses dos membros da sociedade é crucial para o tema do exercício do poder de polícia, justamente porque este poder incide diretamente na liberdade individual, interesse de primeira grandeza para a manutenção da democracia.

Nas palavras de Denílson Luiz Werle ${ }^{526}$ :

O propósito da concepção de democracia deliberativa é determinar um conjunto amplo de procedimentos e condições para os cidadãos formarem juízos sobre questões políticas fundamentais, os quais tenham a seu favor a pretensão de legitimidade e de aceitabilidade racional.

Na democracia deliberativa a noção de igualdade política deve corresponder ao de autonomia política. Neste contexto, as normas e interesses são legítimos na medida em que o grupo destinatário destas normas e interesses é composto por cidadãos livres e iguais e que são passíveis de aceitar as deliberações por meio de uma argumentação racional, pelo uso público da razão.

Neste processo temas como: a limitação do horário de funcionamento de bares e restaurantes em um determinado bairro, a questão do silêncio urbano, o direito de construir, o exercício de determinados comércios, etc., se apresentam com suas características marcantes e por elas são reconhecidos tanto pelos indivíduos que as defendem e as compartilham como pelos seus contrários, fazendo com que ao núcleo do

COELHO, Vera Schattan P., e NOBRE, Marcos (org.), Editora 34, São Paulo, 2004, p.48.( O autor citado é professor de teoria social e política na Research School of Social Sciences, da Australian National University)

${ }^{526}$ WERLE, Denílson Luiz, in: Democracia Deliberativa e os Limites da Razão Pública. Texto integrante da obra: Participação e Deliberação - Teoria Democrática e Experiências Institucionais no Brasil Contemporâneo, COELHO, Vera Schattan P., e NOBRE, Marcos (org.), Editora 34, São Paulo, 2004, pp. 131/137. (o autor citado é Doutor em Filosofia pela Universidade de São Paulo e pesquisador do Núcleo de Direito e Democracia do Centro Brasileiro de Análise e Planejamento - CEBRAP). 
discurso somem-se opiniões sobre fatos e valores numa constante que gera a legitimidade quanto à decisão a ser adotada. ${ }^{527}$

Só a garantia do exercício dos direitos políticos de participação no poder soberano podem garantir uma proteção adequada à vida privada e os direitos inerentes à liberdade. ${ }^{528}$

Fato é que a democracia só apresenta resultados justos quando é assegurado ao cidadão igualdades de oportunidades de participação no processo político e no exercício de influência no resultado do processo deliberativo. Para que a sociedade seja justa, é indispensável que os membros da sociedade estejam conscientes de como funcionam os mecanismos sócio-políticos, especialmente aqueles que a princípio não lhes são aceitáveis.

Não se pode ignorar que níveis desiguais de participação política muitas vezes decorrem da desigualdade de recursos e instrumentos políticos dos membros da sociedade, tais como educação, dinheiro, disponibilidades, etc.

A distribuição desigual de recursos políticos pode conduzir a uma discussão política fundada em percepções falsas das propostas a serem deliberadas e até mesmo a respeito da própria condição ou interesses dos participantes da discussão.

É por isto que a valorização da participação política do cidadão se efetiva pela disponibilização de espaços politizados mais próximos dele (bairro, governo local, o espaço de trabalho, a escola, etc.), locais geralmente não alcançados pela discussão macro-política. A visão de democracia deliberativa deve ser a de um ambiente onde são tomadas decisões coletivas por mecanismos que conduzam a resultados razoáveis, em que os partícipes tenham reais condições de influir.

$\mathrm{Na}$ democracia as liberdades se afirmam como garantias para que os cidadãos possam proteger seus interesses na esfera decisória, mas também como proteção em face das decisões que possam tolher seu direito de expressar suas convicções e seu modo de vida comum. ${ }^{529}$

\footnotetext{
${ }^{527}$ DRYZEK, John S., in, Legitimidade e Economia na Democracia Deliberativa. Texto integrante da obra: Participação e Deliberação - Teoria Democrática e Experiências Institucionais no Brasil Contemporâneo, COELHO, Vera Schattan P., e NOBRE, Marcos (org.), Editora 34, São Paulo, 2004, pp. 49/53.

528 NOBRE, Marcos. In: Participação e Deliberação na Teoria Democrática: Uma introdução, texto integrante da obra: Participação e Deliberação - Teoria Democrática e Experiências Institucionais no Brasil Contemporâneo, COELHO, Vera Schattan P., e NOBRE, Marcos (org.), Editora 34, São Paulo, 2004 , p. 25.

529 ARAÚJO, Cícero, in: Razão Pública, bem comum e decisão democrática. Texto integrante da obra: Participação e Deliberação - Teoria Democrática e Experiências Institucionais no Brasil Contemporâneo, COELHO, Vera Schattan P., e NOBRE, Marcos (org.), Editora 34, São Paulo, 2004, pp. 157/164.
} 
É neste contexto específico que se propõe a ideia de um poder de polícia derivado de um ambiente deliberativo/participativo, onde os membros da comunidade, aptos e conscientes, decidem sobre a melhor forma de atribuir ao Estado um poder legítimo e profícuo. 


\section{VI - CONCLUSÕES}

Conforme pudemos verificar através da pesquisa realizada, o poder de polícia, sem qualquer sombra de dúvidas, é uma das expressões do Poder Público que mais acompanhou as mudanças e evoluções experimentadas pelo Estado.

E nem poderia ser diferente. Como vimos, o poder de polícia é de fato uma função vital ao Estado, sendo mesmo uma de suas características mais marcantes.

Mas o grande desafio a que nos propusemos a enfrentar aqui é o de demonstrar como esta atividade deixou de ser sinônimo de arbitrariedade e despotismo, para se tornar um dos mais importantes instrumentos de ordenação do convívio num Estado Social, Democrático e de Direito.

Com este norte, procuramos dar ênfase ao fato de que, sem um instrumento hábil para dar contornos claros ao exercício dos direitos individuais conquistados nas reformas liberais, a sociedade experimentaria o caos imposto pela lei do mais forte, o que sem dúvida, se mostra tão nocivo quanto o exercício do poder sem limites nas mãos dos soberanos absolutos.

Vimos que se o pensamento liberal e a constitucionalização dos Estados democráticos trouxeram os limites legais ao exercício do poder. Porém, foram as reivindicações de cunho social que impuseram a implementação de contornos ainda mais claros e justos ao exercício do poder de polícia.

Com efeito, no Estado contemporâneo não há mais que se falar em poder de polícia exercido fora da esfera da legalidade ou alheio ao interesse público legítimo. Fora deste contexto, na verdade não há poder de polícia, mais sim, abuso ou desvio de poder, passíveis de toda forma de correção pela própria Administração ou pela via Judicial.

Por fim, pudemos verificar que este modelo de poder de polícia, exercido de modo atento à legalidade e à legitimidade, além de desejável, é absolutamente compatível com um ambiente democrático exercido de modo participativo/deliberativo, no qual a sociedade toma partido ativamente das decisões relevantes que lhes afetam o exercício dos direitos e liberdades.

Tal constatação é de suma importância na medida em que hodiernamente se vive de modo cada vez mais intenso e concentrado nas grandes cidades, 
o que exige do Estado uma atividade cada vez mais invasiva e onipresente, exercida através do poder de polícia.

Neste cenário, o Direito Administrativo atualizado apresenta um poder de polícia que, tendo extrapolado o seu viés negativo e limitado, passa a incidir nas mais variadas áreas da vida, requerendo, por sua vez, uma participação cada vez mais ativa dos sujeitos que sofrerão a sua incidência, de modo que a submissão à atuação estatal se dê em parâmetros os mais aceitáveis e eficazes possíveis.

De fato, podemos notar a atuação do poder de polícia (em sentido amplo) nas mais variadas áreas, tornando premente a participação popular na implementação das decisões de polícia administrativa que lhes afetam.

Para implantação deste ambiente participativo têm sido propostos os mais variados mecanismos, como exemplo, os denominados "Conselhos Comunitários de Segurança"530. Tais espaços públicos de discussão, com uma composição mista, com elementos do Poder Público e das mais variadas representações da sociedade, têm toda vocação para a modulação do exercício do poder de polícia em suas regiões, cooperando significativamente na implantação de políticas de ordenação urbana e na adequada restrição do exercício das liberdades e direitos. Nestes Conselhos, que podem ser estadual, municipal ou regional, podem ser deliberadas quais as políticas e quais as medidas de polícia mais apropriadas para o âmbito de sua abrangência.

A participação ativa da comunidade envolvida (moradores, comerciantes, ambulantes, associações, etc.), promove uma política de restrições mais adequada e afinada com os anseios do cidadão que, como vimos, reconhece como legítima a atuação do Poder Público no momento da implantação das medidas de polícia.

Tais deliberações podem abranger desde matérias relativas ao uso e ocupação do solo (posturas municipais); a restrição à utilização dos recursos naturais e a exploração do meio ambiente; a utilização dos espaços públicos e calçadas para o comércio ambulante; o funcionamento de bares e restaurantes, etc.

Em grandes cidades, tais mecanismos ganham importância na medida em que, por óbvio, uma atividade intolerável em uma região poderia ser considerada benéfica em outra. A participação da comunidade local, por exemplo, poderia ser decisiva na elaboração das leis e dos planos de fiscalização de comércios locais, tornando a ação de polícia uma atividade altamente desejável e eficaz na localidade.

\footnotetext{
${ }^{530}$ QUEIROZ, Raphael Augusto Sofiati de, Direito Público \& Segurança Pública - Ensaios e Pareceres, Editora Lumen Juris, Rio de Janeiro, 2001, pp. $49 / 50$.
} 
$\mathrm{Na}$ prática, grandes centros urbanos já têm lançado mão de mecanismos modernos para o exercício do poder de polícia, denotando claramente a importância desta função para a sociedade hodierna.

Na cidade de São Paulo, por exemplo, foi implantado com sucesso o denominado PSIU - Programa do Silêncio Urbano ${ }^{531}$, que vem tentando enfrentar, com o auxílio da população, o grave problema da perturbação do ambiente causado pelo excesso de barulho, especialmente no período noturno.

Podem ser apontados outros exemplos atuais de medidas legais ou de cunho administrativo que demonstram a relevância do poder de polícia no Estado contemporâneo, tais como:

- Na legislação federal, a edição do "Estatuto da Cidade", Lei 10.257/01, que prevê mecanismos para "ordenação e controle do uso do solo" art. 2 , inciso VI); a possibilidade de lei municipal, incluída no plano diretor, poder determinar o

${ }^{531}$ Apenas a título de ilustração seguem alguns números do trabalho do, implementado em São Paulo pelo Decreto Municipal n ${ }^{\circ} 34.569 / 94$, obtidas no site: www.prefeitura.sp.gov.br

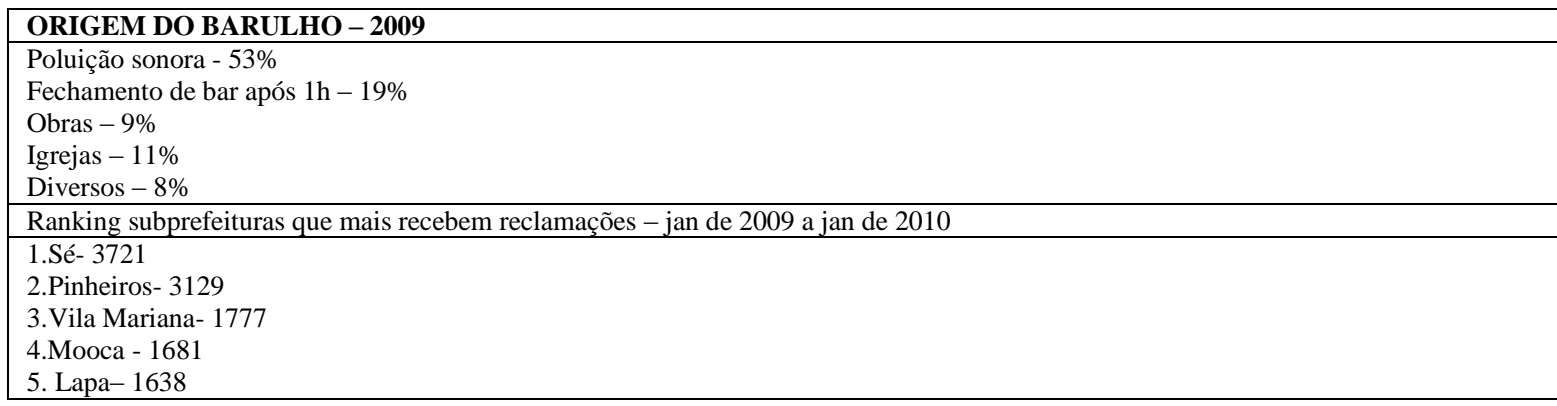

Números - fiscalização geral 2005 - Fev/2010

\begin{tabular}{|c|c|c|c|c|c|c|c|}
\hline Ano & 2005 & 2006 & 2007 & 2008 & 2009 & 2010 & Até ago/ 2011 \\
\hline Reclamações Recebidas & 30.495 & 32.272 & 37.114 & 42.075 & 33.673 & 29.046 & 18.838 \\
\hline Atendimentos Realizados & 14.388 & 23.351 & 28.764 & 33.884 & 35.511 & 32.114 & 21.421 \\
\hline $\begin{array}{l}\text { Notificação } \\
\text { após 1h - Lei 12.879 }\end{array}$ & 975 & 739 & $21(*)$ & 0 & 0 & 0 & 0 \\
\hline Comunicados & & & & 11.889 & 14.116 & 11.920 & 7.692 \\
\hline Multa e Lacração p/ bares abertos após1h - Lei 12.879 & 158 & 127 & 412 & 254 & 885 & 603 & 453 \\
\hline Multas de Ruído & 213 & 74 & 221 & 224 & 270 & 155 & 82 \\
\hline Fechamento Administrativo / Policial & 66 & 88 & 109 & 48 & 138 & 186 & 142 \\
\hline $\begin{array}{l}\text { Multas } \\
\text { em milhões (aprox.) }\end{array}$ & $\mathrm{R} \$ 8,2$ & $\mathrm{R} \$ 7,8$ & $\mathrm{R} \$ 15,5$ & $\mathrm{R} \$ 12$ & $\mathrm{R} \$ 28$ & $\mathrm{R} \$ 21$ & $\mathrm{R} \$ 16.2$ \\
\hline
\end{tabular}

* A partir de 20/06/07 adotada a medida administrativa de não mais notificar, apenas comunicar via correio com o mesmo efeito da notificação (Portaria nº 025/SMSP/SEC/2007) 
parcelamento, a edificação ou a utilização compulsória do solo urbano não edificado, subutilizado ou não utilizado (art. $5^{\circ}$ ), deixando patente aí o caráter ativo do poder de polícia moderno; a imposição de que o Plano Diretor das cidades seja desenvolvido de modo participativo, com a realização de audiências públicas e debates, com a participação de representantes da sociedade - caráter participativo/deliberativo - (artigo 40, §4 $4^{\circ}$, inciso I);

- Em âmbito Regional, a “Operação Defesa das Águas”, que é um conjunto de medidas previstas através de Convênio ${ }^{532}$ firmado entre a Prefeitura de São Paulo e o Governo do Estado visando especialmente fiscalizar e controlar as atividades nos mananciais: Guarapiranga, Billings e seu entorno (na Zona Sul) e das matas, córregos e nascentes, na Zona Norte, com ações levadas a efeito por órgãos do Governo do Estado (Secretarias do Meio Ambiente, Saneamento e Energia/Sabesp/EMAE, Habitação/CDHU, e Segurança Pública), e da Prefeitura (Secretarias do Verde e Meio Ambiente, das Subprefeituras, da Habitação, do Governo/Guarda Civil Metropolitana), sob responsabilidade da Secretaria de Governo do Município;

-No âmbito local, a limitação da exploração do espaço visual da cidade com a edição da Lei 14.223 de 26/09/06, conhecida como "Lei Cidade Limpa" que promoveu uma verdadeira revolução no uso de propagandas, anúncios, fachadas de estabelecimentos, tendo proibido a exibição de "out-doors" em toda cidade de São Paulo.

Enfim, resta notório que o poder de polícia, longe de ter se diluído ou perdido sua importância como sustentaram alguns doutrinadores pesquisados, na verdade revigorou-se, tendo sido alçado a um patamar de atividade indispensável ao convívio social hodierno. Ao contrário, a omissão do Estado quanto ao exercício do poder de polícia é que se tornou intolerável.

Conclui-se, pois, que exercido dentro do âmbito da legalidade e de modo legítimo, o poder de polícia apresenta-se como um instrumento adequado, eficaz e indispensável para ao Estado contemporâneo, impondo-se como uma das matérias mais relevantes do Direito Administrativo atual.

\footnotetext{
${ }^{532}$ Convênio acessível através do site: www.prefeitura.sp.gov.br/cidade/secretarias/seguranca_urbana/defesa_das_aguas/
} 


\section{BIBLIOGRAFIA/REFERÊNCIAS:}

- ALONSO, Anníbal Martins, Poder de Polícia, Polícia Administrativa, Polícia Judiciária, 1954.

- AMARAL, Antônio Carlos Cintra, Teoria do Ato Administrativo, Editora Fórum, Belo Horizonte, 2008.

- AMARAL, Antônio Carlos Cintra, O Princípio da Eficiência no Direito Administrativo, in Revista Eletrônica sobre a Reforma do Estado, nº 05, março/maio, Salvador, 2006.

- ARAÚJO, Edmir Netto de, Curso de Direito Administrativo, Saraiva, $5^{\text {a }}$ Ed., São Paulo, 2010

- ARAÚJO, Edmir Netto de, Do Negócio Jurídico Administrativo, Ed. Revista dos Tribunais, São Paulo, 1992.

- ÁVILA, Humberto, Teoria dos Princípios, da Definição à Aplicação dos Princípios Jurídicos, Editora Malheiros, $7^{\text {a }}$ ed., São Paulo, 2007.

- BANDEIRA DE MELLO, Celso Antônio, Curso de Direito Administrativo, Malheiros, $21^{\text {a }}$ ed., São Paulo, 2006.

- BANDEIRA DE MELLO, Celso Antônio, Grandes Temas de Direito Administrativo, Malheiros, São Paulo, 2009.

- BANDEIRA DE MELlo, Celso Antônio, Serviço Público e Poder de Polícia: Concessão e Delegação, in Revista Eletrônica de Direito do Estado, nº 7, julho/setembro, Salvador, 2006.

- BARROS, Sérgio Resende de, Contribuição Dialética para o Constitucionalismo. Millenium, Campinas, SP, 2007.

- BARROS, Sérgio Resende de, "Estado de Direito" - Texto integrante do curso: "A Negação do Estado de Direito pelo Estado de Legalidade - Curso de Pós Graduação da Faculdade de Direito da USP-SP, $2^{\circ}$ semestre de 2010.

- BEZNOS, Clóvis, Poder de Polícia, Revista dos Tribunais, São Paulo, 1979.

-BOBBIO, Norberto, Estado, Governo, Sociedade - Para uma teoria geral da política, 4 ed., Editora Paz e Terra, Rio de Janeiro, 2007.

- BONAVIDES, Paulo, Do Estado Liberal ao Estado Social, Malheiros Editores, 9a ed., São Paulo, 2009.

- BONAVIDES, Paulo, Teoria Constitucional da Democracia Participativa, Malheiros Editores, $3^{\mathrm{a}}$ ed., São Paulo, 2008. 
- CANOTILHO, JJ Gomes, Direito Constitucional e Teoria da Constituição, $4^{a}$ edição, Livraria Almedina, Coimbra, 1993.

- CASSAgne, Juan Carlos, Derecho Administrativo, 6a Ed., Abeledo-Perrot, Buenos Aires, 2000.

- CAVAlCANTI, Themístocles Brandão, Princípios Gerais de Direito Administrativo, Editora Freitas Bastos, São Paulo, 1945.

- CIRNE LIMA, Ruy, Princípios de Direito Administrativo, Malheiros Editores, $5^{\text {a }}$ Ed., São Paulo, 1982.

- COELHO, Fábio Ulhoa, Direito e Poder, Editora Saraiva, São Paulo, 2010.

- COELHO, Vera Schattan P., e NOBRE, Marcos (org.), Participação e Deliberação Teoria Democrática e Experiências Institucionais no Brasil Contemporâneo, Editora 34, São Paulo, 2004.

- CRETELLA JR., José, Do Poder de Polícia, Rio de Janeiro, Forense, 1999.

- CRETELLA JR., José, Do Desvio de Poder, Editora RT, São Paulo, 1964.

- CRETELLA JR., José, Direito Administrativo Brasileiro, Editora Forense, $2^{\text {a }}$ edição, Rio de Janeiro 2.000.

- CRETELLA JR, José, Prerrogativas e Sujeições da Administração Pública, in Revista de Direito Administrativo, volume 103, Rio de Janeiro, janeiro a março de 1971.

- CRUZ, Paulo Márcio, Política, Poder, Ideologia e Estado Contemporâneo, $2^{\text {a }}$ ed., Juruá, Curitiba, 2002.

- DAHL, Robert Alan, Análise Política Moderna, Ed. Universidade de Brasília, Brasília, 1981.

- DI PIETRO, Maria Sylvia Zanella, Direito Administrativo, Atlas, 20ª Ed., São Paulo, 2007.

- DI PIETRO, Maria Sylvia Zanella, Poder de Polícia em Matéria Urbanística, in Temas de Direito Administrativo, Publicação conjunta, Ministério Público de São Paulo/Imprensa Oficial, São Paulo, 1999.

- DI PIETRO, Maria Sylvia Zanella, Poder de Polícia, in Revista de Direito Público, São Paulo, v 24, no 98, pg. 90-4, abr./jun. 1991.

- DI PIETRO, Maria Sylvia Zanella, Participação Popular na Administração Pública, in Revista de Direito Administrativo, no 191, p 26-39 - janeiro a março de 1993.

- ENTERRÍA, Eduardo Garcia de, e FERNANDÉZ, Thomás-Ramón. Curso de Derecho Administrativo, 4ª Ed., Vol II, Civitas, Madri, 1997. 
- FALZONE, Guido, Il dovere di buona ammnistrazione, Giufrè Editore, Milão, 1953.

- FERREIRA, Daniel, Poder de Polícia, in Curso de Direito Administrativo, Marcelo Harger (org.) Ed. Forense, Rio de Janeiro, 2007.

- FERREIRA FILHO, Manoel Gonçalves, Princípios Fundamentais do Direito Constitucional, Editora Saraiva, São Paulo, 2009.

- FERREIRA FILHO, Manoel Gonçalves, Aspectos do Direito Constitucional Contemporâneo, $2^{\text {a }}$ ed., Saraiva, São Paulo, 2009.

- FIGUEIREDO, Lúcia Valle, Curso de Direito Administrativo, $9^{a}$ edição, Malheiros, São Paulo, 2008.

- FIGUEIREDO, Lúcia Valle. Instrumentos da Administração Consensual: A Audiência Pública e sua Finalidade, in Revista Eletrônica de Direito Administrativo Econômico, $\mathrm{n}^{\circ}$ 11, agosto/outubro de 2007, Salvador.

- FIORINI, Bartolome, Poder de Polícia, Editora Alfa, Buenos Aires, 1962.

- FIORINI, Bartolome, Derecho Admnistrativo, Ed. Abeledo-Perrot, $2^{a}$ edição atualizada, Abeledo-Perrot, Buenos Aires, 1976.

- FRAGA, Gabino, Derecho Administrativo, Porrúa, México, 1968.

- FREITAS, Juarez, Poder de Polícia Administrativa - Novas Reflexões, BDA/Boletim de Direito Administrativo 6/657-668, Ed. Nova Dimensão, São Paulo, Junho de 2006.

- GARCIA VITTA, Heraldo, Poder de Polícia, Malheiros Editores, São Paulo, 2010.

- GASOS, Iara Leal, A Omissão Abusiva do Poder de Polícia, Lumen Juris, Rio de Janeiro, 1994.

- GASPARINI, Diógenes, Direito Administrativo, 7ª ed., Saraiva, São Paulo, 2002.

- GORDILlO, Augustin A., Tratado de Derecho Administrativo, Parte Geral - Tomo II, Editores Macchi-Lopez, Buenos Aires, 1975.

- GRAU, Eros Roberto, O Direito Posto e o Direito Pressuposto, $7^{\text {a }}$ ed., Malheiros, São Paulo, 2008.

- GRAU, Eros Roberto, Poder de Polícia: Função Administrativa e Princípio da Legalidade: O Chamado "Direito Alternativo", Revista Trimestral de Direito Público, no 01/1993, Editora Malheiros.

- GROTTI, Dinorá Adelaide Musetti, Poder de Polícia - Palestra proferida no Seminário Nacional de Direito Administrativo - Edição Comemorativa dos 20 anos da NDI, BDS/Boletim de Direito Administrativo, 7/753-758, Ed. Nova Dimensão Jurídica, Junho 2006 
- HABERMAS, Jürgen, A Crise de Legitimidade no Capitalismo Tardio, Edições Tempo Brasileiro, Rio de Janeiro, 1999.

- HABERMAS, Jürgen, Direito e Democracia - entre a facticidade e validade - vol. I, Biblioteca Tempo Brasileiro, Rio de Janeiro, 2.010.

- HABERMAS, Jürgen, Direito e Democracia - entre a facticidade e validade - vol. II, Biblioteca Tempo Brasileiro, Rio de Janeiro, 2.010.

- KELSEN, Hans, Teoria Pura do Direito. $6^{a}$ ed., Tradução de José Cretella Jr. e Agnes Cretella, Editora Revista dos Tribunais, São Paulo, 2009.

- JOUVENEL, Bertrand de, O Poder - História natural de seu crescimento, Ed. Peixoto Neto, São Paulo, 1998.

- JUSTEN FILHO, Marçal, Curso de Direito Administrativo, $3^{\text {a }}$ edição, Saraiva, São Paulo, 2008.

- LAZZARINI, Álvaro, Temas de Direito Administrativo, $2^{\text {a }}$ ed., Editora Revista dos Tribunais, São Paulo, 2003.

- LOYN, Henry R., Dicionário da Idade Média, Jorge Zahar Editor Ltda., Rio de Janeiro, 1997.

- MALBERG, Raymond Carré de. Contribution à la Theorie Générale de l'État. Tomo I, Libreairie de la Socièté du Recueil Sirey, Paris, 1920.

- MALUF, Sahid, Teoria Geral do Estado, 28º ed., Saraiva, São Paulo, 2008.

- MARQUeS NETO, Floriano Peixoto de Azevedo, Regulação Estatal e Interesses Públicos, Malheiros, São Paulo, 2002.

- MARQUES NETO, Floriano Peixoto de Azevedo, Aspectos Jurídicos do Exercício do Poder de Sanção por Órgão do Setor de Energia Elétrica, in Revista de Direito Administrativo, volume 221, Rio de Janeiro, renovar, 2000.

- MAXIMILIANO, Carlos, Hermenêutica e Aplicação do Direito, 19ª ed., Ed. Forense, Rio de Janeiro, 2010.

- MAYER, Otto, Derecho Administrativo Alemán, Ed. Depalma, Buenos Aires, 1950.

- MEDUAR, Odete, Direito Administrativo Moderno, $3^{\text {a }}$ ed., São Paulo, 1999.

- MEDUAR, Odete, Poder de Polícia, in Boletim de Direito Administrativo, São Paulo, v. 12, no 12, p. 814-9, dezembro de 1996.

- MEDUAR, Odete, Auto-Executoriedade do Ato Administrativo, in Boletim de Direito Administrativo, v. 2, p 515-519, julho de 1986. 
- MEIRELLES, Hely Lopes, Direito Administrativo Brasileiro, 17 a ed., Malheiros Editores, São Paulo, 1992.

- MEIRELLES, Hely Lopes, Direito Municipal Brasileiro, 12a ed., Malheiros Editores, São Paulo, 2001.

- MENDES, Conrado Hübner, Controle de Constitucionalidade e Democracia, Campus Jurídico, Rio de Janeiro, 2008.

- MIRANDA, Jorge, Funções, Órgãos e Atos do Estado, Universidade de Lisboa, 1990.

- MONTORO, Franco, Alternativa Comunitária, um caminho para o Brasil, Ed. Nova Fronteira, Rio de Janeiro, 1982.

- MONTORO, Franco, Da Democracia que Temos para a Democracia que Queremos, Ed. Paz e Terra, Rio de Janeiro, 1974.

- MORAES, Alexandre de, Direito Constitucional Administrativo, $4^{\mathrm{a}}$ ed., Atlas, São Paulo, 2007.

- MOREIRA NETO, Diogo de Figueiredo, Mutações do Direito Administrativo, $2^{a}$ ed., Renovar, Rio de Janeiro, 2001.

- MOREIRA NETO, Diogo de Figueiredo, Curso de Direito Administrativo, 15 a ed., Ed. Forense, 2009.

- MOREIRA NETO, Diogo de Figueiredo, Quatro Paradigmas do Direito Administrativo Pós-Moderno, Ed. Forense, Rio de Janeiro, 2008.

- MOREIRA NETO, Diogo de Figueiredo, Novas Tendências da Democracia: Consenso e Direito Público na Virada do Século - O Caso Brasileiro, in Revista Eletrônica sobre a Reforma do Estado, n⿳亠丷 13, março/abril/maio de 2008, Salvador.

- MÜLLER, Friedrich, Quem é o Povo? A Questão Fundamental da Democracia, Ed. Revista dos Tribunais, $4^{\mathrm{a}}$ ed., São Paulo, 2009.

- NOBRE, Marcos e TERRA, Ricardo (organizadores). Direito e Democracia - Um Guia de Leitura de Habermas, Ed. Malheiros, São Paulo, 2008.

- OLIVEIRA, Gustavo Henrique Justino de, Participação Administrativa, in Revista Eletrônica sobre a Reforma do Estado, nº 03, setembro/novembro de 2005, Salvador.

- OSÓRIO, Fábio Medina, Direito Administrativo Sancionador, $3^{\text {a }}$ ed., Editora Revista dos Tribunais, São Paulo, 2009.

- PEStanA, Márcio, Direito Administrativo Brasileiro, Campus Jurídico, Rio de Janeiro, 2008.

- PIRES, Luis Manuel Fonseca, Limitações Administrativas à Liberdade e à Propriedade, Quartier Latin, São Paulo, 2006. 
- QUEIROZ, Raphael Augusto Sofiati de, Direito Público \& Segurança Pública Ensaios e Pareceres, Editora Lumen Juris, Rio de Janeiro, 2001.

- RIVERO, Jean, Curso de Direito Administrativo Comparado, Apostila, Tradução José Cretella Jr., Editora Revista dos Tribunais, São Paulo, 2004.

- ROMANO, Santi, Principi di Diritto Constitucionale Generale, Ed. Giufrè, Milano, 1947.

- SANTOS, Boaventura de Souza (org.). Democratizar a Democracia: os caminhos da democracia participativa, Civilização Brasileira, Rio de Janeiro, 2002.

- SCHIMITT, Carl, Teologia Política, Editorial Struhart e Cia, Cochabamba, 1998.

- SCHIMITT, Carl, Legalidade e Legitimidade, Ed. Del Rey, Belo Horizonte, 2007.

- SILVA, José Afonso da, Curso de Direito Constitucional Positivo, 22ª ed., Malheiros Editores, São Paulo, 2003.

- SIRAQUE, Vanderlei, Controle Social da Função Administrativa do Estado, Ed. Saraiva, $2^{a}$ ed., São Paulo, 2009.

- SPINOZA, Baruch, Tratado Político, Ícone Editora, 2a ed., São Paulo, 1994.

- COMTE-SPONVILLE, André, Pequeno Tratado das Grandes Virtudes, Martins Fontes, São Paulo, 2007.

- SUNDFELD, Carlos Ari, Fundamentos de Direito Público, $4^{\mathrm{a}}$ ed., Malheiros Editores, São Paulo, 2009.

- SUNDFELD, Carlos Ari, Direito Administrativo Ordenador, Malheiros Editores, São Paulo, 2003.

- TÁCITO, Caio, Poder de Polícia e Polícia do Poder, in: Direito Administrativo da Ordem Pública, (obr. Coletiva), $2^{a}$ ed., Editora Forense, Rio de Janeiro, 1987.

- TÁCITO, Caio, Temas de Direito Público (Estudos e Pareceres), Renovar, Rio de Janeiro, 1997.

- VASQUEZ, Ramon, Poder de Polícia, 2a ed., Ed. F. Dias, Buenos Aires, 1957. 